\title{
Estudo da Transmissão de Malária em população ribeirinha do Estado do Amapá, Brasil- Sorologia humana e uso de ELISA em anofelinos.
}

Maria Stela Branquinho

Tese de Doutorado apresentada ao Departamento de Epidemiologia da Faculdade de Saúde Pública da Universidade de São Paulo para obtenção do Grau de Doutor

Área de Concentração:

Epidemiologia

ORIENTADOR: PROF. DR. JOSÉ MARIA SOARES BARATA

\author{
SÃO PAULO
}




\section{Maria Stela Branquinho}

Estudo da Transmissão de Malária em população ribeirinha do Estado do Amapá, Brasil- Sorologia humana e uso de ELISA em anofelinos.

ORIENTADOR: Prof. Dr. José Maria Soares Barata

São Paulo 
Aos meus pais, Ivan e Maria Augusta, com todo o meu amor.

Ao meu querido esposo Luiz pelo amor e companheirismo, ao longo de todos estes anos.

Aos queridos irmãos Ana e Ivo, com muito amor. 

Em especial às Amigas

Ana Maria R.C.Duarte

Izilda Curado

Rosely dos Santos Malafronte

AMTGO E AQUELE QUE CHEGA QUANDO TODO MUNDO JÁ SE FOI

Autor desconhecido

Obrigada 


\section{Agradecimentos}

Em especial, ao amigo Jaco Voorham pela inestimável colaboração, sem a qual seria impossivel realizar este trabalho.

A Sabrina dos Santos Ruiz, amiga de todas as horas pela grande amizade e ajuda no trabalho de campo e na realização dos testes laboratoriais.

À Maura Antonia Porto pela amizade e solidariedade demonstradas, que me foram muito importante e pelo auxilio nos testes sorológicos.

Ao Dr. Almério de Castro Gomes pelo incentivo constante à minha carreira e pelo fornecimento de parte dos peptideos sintéticos, sem os quais seria impossivel realizar este trabalho.

Ao Dr. Heitor F. de Andrade Jr., do Laboratório de Protozoologia do Instituto de Medicina Tropical de São Paulo, por colocar-me à disposiçāo infraestrutura e reagentes.

Em especial, à Dra. Ligia B. Iversson, pela minuciosa revisão do texto, pelas criticas e sugestōes dadas a este trabalho e pelo exemplo de dignidade e competência na esfera cientifica.

Ao Dr. Cláudio dos Santos Ferreira pela ajuda na parte estatistica, pela leitura critica e pelo exemplo de vida.

Em especial ao Dr. Marcelo Urbano agradeço pela leitura cuidadosa pelas criticas e valiosas sugestōes e pelo exemplo de competência e humildade em que muito me espelho

Ao Dr. Marcos Boulos pela leitura atenta, pela disponibilidade para me ajudar sempre que necessito e pelas sugestōes apresentadas que muito contribuiram para o aperfeiçoamento deste trabalho

À Dra. Ruth Nussenzweig pelo fornecimento dos hibridomas pelos reagentes e pelo constante incentivo dado a minha carreira.

À Mônica Leal pela ajuda prestada na produção dos anticorpos monoclonais e auxilio sempre que solicitado 
À Dra Júlia Manso pelo valioso treinamento na produção dos anticorpos monoclonais.

Ao amigo Paulo Roberto do Nascimento pela ajuda na tabulação dos dados e na análise epidemiológica.

À amiga-irmā Claudia Barleta do Nascimento pela grande amizade e pelo carinho sempre presente durante os últimos vinte anos.

Ao Almir Robson Ferreira pela confecção dos mapas e pela ajuda oferecida sempre que solicitada.

À Sabrina dos Santos Ruiz e ao Dr. José Maria Soares Barata pela confecção das lindas fotos apresentadas neste trabalho

À querida cunhada Nanci Leite Branquinho pela grande amizade e pela confecção das tabelas.

À Laurinda Grion, querida cunhada pela revisão minuciosa do português.

Ao Alberto Riccardo Papa pela confecção das imagens e pela presteza sempre que solicitada.

Ao Conselho Nacional de Pesquisa Cientifica e Tecnológ ca (CNPq), Superintendência de Controle de Endemias- SUCEN e Laboratório de Investigação Médica (LIM 49) pelo apoio financeiro na realização deste trabalho.

Ao Superintendente da Superintendência de Controle de EndemiasSUCEN Dr. Luiz Jacintho da Silva pelo apoio a este trabalho

Ao Departamento de Epidemiologia da Faculdade de Saúde Pública, representado pelo Dr. Almério de Castro Gomes, pelo empenho para a obtenção de financiamento das passagens e estadias no estado do Amapá. 


\section{RESUMO}

Branquinho MS. Estudo da Transmissão de Malária en população ribeirinha do Estado do Amapá, Brasil- Sorologia humana e uso de ELISA em anofelinos, São Paulo (BR); 2001 [Tese de Doutorado- Faculdade de Saúde Pública da USP].

Objetivo: Caracterizar a transmissão da malária quanto aos vetores e a população humana, em área tipicamente ribeirinha do Estado do Amapá

Material e métodos. Amostras de sangue de 163 indivíduos residentes em três localidades do Estado do Amapá foram submetidas a testes parasitológicos (gota espessa e esfregaço sangüíneo) e sorológicos (imunofluorescència indireta e ELISA). Na reação de Imunofluorescência indireta usou-se antígeno de formas assexuadas de Plasmodium vivax e P.falciparum para a pesquisa de imunoglobulinas IgG e IgM. O ELISA foi realizado com peptídeos sintéticos correspondentes à região repetitiva da proteína circunsporozoíta de $P$. faiciparum, $P$. malariae; $P$. vivax, $P$. vivax VK247 e $P$. vivax-like. Um total de 9450 An. darlingi e 3.523 An. albitarsis foram processados pelo ELISA para a verificação de positividade com os cinco Plasmodium acima mencionados

Resultados. Os testes parasitológicos mostraram 14 individuos positivos (7 pelo P.falciparum, 6 pelo P.vivax e 1 P.falciparum + P.vivax). As 73 amostras analisadas pela Imunofluorescência Indireta resultaram: P. falciparum $30,1 \%$ (IgG) e $16,4 \%$ ( $\lg M)$; $P$. vivax $71,2 \%(\operatorname{lgG})$ e $13 \%(\lg M)$. Os resultados no ELISA foram: P.vivax 38,4\% (28/73), P.falciparum 26\% (19/73), P. malariae 36,7\% (27/73), P.vivax VK 247 20,5\% (15/73) e P.vivax like 17,8\% (13/73).

O estudo anofélico mostrou a presença do An. darlingi e An albitarsis os quais foram positivos para os cinco plasmódios. No An darlingi o $P$. vivax like foi o mais encontrado (1,03\%), seguido do P.vivax VK247 (0,6\%), P.vivax $(0,12 \%), P$. falciparum $0,06 \%$ e P.malariae $0,04 \%$. No An. albitarsis encontrou-se $0,6 \%$ de positividade para $P$.vivax like e $P$. vivax VK247 
Discussão. O conhecimento da dinâmica de transmissão com o estabelecimento de adequada incriminação vetorial das espécies de Plasmodium circulantes é pré-requisito para o correto direcionamento de estratégias a serem adotadas pelas autoridades de controle. A alta porcentagem de anticorpos presente na população por nós estudada aliada, à presença de casos assintomáticos e o encontro de positividade nos anofelinos mostraram a necessidade do estabelecimento de pesquisas mais sistematizadas nos diferentes quadros brasileiros.

Descritores. Malária. Anophelinos. Epidemiologia. ELISA. 


\section{SUMMARY}

Branquinho MS. Study of the transmission of Malaria in a riverside population of the State of Amapa, Brazil- Human serum and the use of ELISA in the study of anophelines. São Paulo (BR); 2001.|Tese de Doutorado- Faculdade de Saúde Pública da USP]

Objective. A description of the transmission of malaria in terms of vectors and human population in a typical riverside area in the State of Amapá.

Material and mothods. Blood samples taken from 163 individuals living in three localities in the State of Amapá were submitted to parasitological (thick drip and blood-smear) and serum (indirect immunofluorescence and ELISA) tests. In the indirect immunofluorescence reaction the antigen of asexual forms of Plasmodium vivax and $P$.falciparum were used for the research on IgG and IgM immunoglobulin. ELISA was done using the synthetic peptides corresponding to the repetitive region of the circumsporozoitic protein of P.falciparum, P.malariae, P.vivax VK 247 and P.vivax-like. A total of 9,450 An. darlingi and 3,523 An. albitarsis were submitted to ELISA to verify positive reaction to the five plasmodia mentioned above.

Results. The parasitological tests presented 14 positive individuals ( 7 for P.falciparum, 6 for P.vivax and 1 for P.falciparum + P.vivax). The: 73 samples analyzed by indirect immunofluorescence gave the following results P. falciparum $30,1 \%(\operatorname{lgG})$ and $16,4 \%(\operatorname{lgM}) ; P$. vivax $71,2 \% \%(\operatorname{lgG})$ and $13 \%$ (IgM). The ELISA results were: $P$. falciparum $26 \%, P$. vivax $38.4 \%$, P.malariae $36,7 \%$, P.vivax VK247 $20,5 \%$ and P.vivax like $17,8 \%$

The study of the anophelines showed a predominant presence of An.darlingi and An.albitarsis. which were positive for the five plasmodia studied. In An.darlingi the P.vivax-like was the most frequently found (1.03\%), followed by P.vivax VK 247 (90.6\%), P.vivax (0.12\%), P. fah., arum 
(0.06\%) and P.malariae (0.04\%). In An.albitarsis a positive reaction of $0.6 \%$ was found for both P.vivax-like and P.vivax VK247.

Discussion. The knowledge of the dynamics of the transmission with the establishment of adequate vectorial incrimination of the circulating species of Plasmodium is the fundamental prerequisite for the correct orientation of the strategies to be adopted by the controlling authorities. The high percentage of antibodies present in the population studied, together with the presence of asymptomatic cases and the positive reaction found in the anophelines demonstrated the need for more Brazilian epidemiological scene.

Descriptors:. Malaria. Anophelines. Epidemiology. ELISA. 


\section{ABREVIAÇÕES}

A- Adenosina

a.C.- antes de Cristo

D- Ácido aspártico

$\mathrm{N}$ - Alanina

An. - Anopheles

Ac Mo- Anticorpo monocional

AP - Amapá

A- Asparagina

${ }^{\circ} \mathrm{C}$ - Grau Celsius

BM - Banho Maria

DDT - Dicloro-difenil-tricloretano

DNA - Ácido desoxirribonucléico

DO - Densidade Óptica

DP - Desvio Padrão

ELISA- Enzyme Linked Immunosorbent Assay

FUNASA - Fundação Nacional da Saúde

G- Glicina

Q- Glutamina

IFI - Reação de Imunofluorescência Indireta

IgG - Imunoglobulina G

IgM - Imunoglobulina M

Ker. - Kerteszia

M - Molar

MGT - Média Geométrica dos Títulos

$\mu \mathrm{l}$ - Microlitros 
Min.- minuto

$\mathrm{ml}$ - Mililitros

mg- miligramas

Mm - Milimetros

$\mathrm{mm}^{3}$ - Milimetros cúbicos

N - Norte

$\mathrm{Ng}$ - nanogramas

Nys - Nyssorhynchus

OMS - Organização Mundial da Saúde

ONGs- Organizações não Governamentais

OPAS - Organizacion Pan Americana de La Salud

P.falciparum - Plasmodium falciparum

P.malariae - Plasmodium malariae

P.ovale - Plasmodium ovale

P.vivax - Plasmodium vivax

PBS - Tampão salina fosfato

PCR - Reação em cadeia de polimerase

Prolina - $P$

Proteina circunsporozoíta - CS

pH-Potencial hidrogeniônico

Rpm - rotação por minuto

S - Sul

TA- Temperatura ambiente

U- Unidade de enzima

W-Oeste

WHO - World Health Organization 
REAGENTES EMPREGADOS

Azul de Evans- Sigma E-2129

Aprotinina- Sigma - A 1153

Cloreto de sódio - Merk 6404

Conjugado peroxidase-estreptoavidina e biotina- Calbiochem [iagnost213188

Cloreto de amônio (NH4)Cl, 1M- Sigma A 4514

Antipaina- Sigma- A 6271

Dimetil sulfoxido (DMSO) - Sigma D 5879

Dodecil Sulfato de Sódio (SDS)- Sigma L-4390

Fosfato de Sódio Dibásico- Sigma S0876

Glicerol- Sigma 7893

Imunoglobulina de cabra anti- IgM humana, cadeia gama especifica, marcada com isotiocianato de fluoresceina- Biolab 022010

Imunoglobulina de cabra anti- IgG humana, cadeia gama especifica, marcada com isotiocianato de fluoresceina- Biolab 022009

Imunoglobulina de cabra anti- IgG humana, cadeia gama especifica, marcada com peroxidase- Sigma A8419

Imunoglobulina de cabra anti- IgG de camundongo, cadeia gama esfiecifica. marcada com peroxidase- Sigma A-3673 


\section{LISTA DE FIGURAS}

Figura 1: Evolução do número de casos de malária notificados no Es ado do Amapá, Brasil, 1985-2000. Fonte: (MS/FUNASA, 2000).

Figura 2: Número de casos notificados, por espécie na área de estudo Junho 1998 - Novembro 1999 Fonte: FUNASA/ MS. 2000

Figura 3- Fotografia mostrando uma paisagem típica da localidade de São Raimundo de Pirativa, Amapá, março, 2000.

Figura 4: Fotografia mostrando aspectos da infraestrutura básica de saneamento presente na região do rio Matapi, Amapá, março, 2000.

Figura 5: Fotografia mostrando o meio de transporte utilizado pela Secretaria da Educação do Estado do Amapá na região do rio MatapiAmapá, março 2000.

Figura 6: Fotografia mostrando uma moradia tipica encontrada nas localidades de São Raimundo, Santo Antonio e São João, Amapá, março 2000.

Figura 7: Fotografia de moradores da região do Rio Matapi, estado do Amapá, março 2000.

Figura 8: Distribuição dos títulos das reações de IFI para anticorpos $\lg G_{\text {e }}$ e IgM de Plasmodium falciparum e Plasmodium vivax da população residente na região do rio Matapi, março 2000.

Figura 9: Distribuição das absorbâncias a $414 \mathrm{~nm}$ obtidas em ELISiA com soros da população de São Raimundo, Amapá - Março 2000

Figura 10: Distribuição das absorbâncias a $414 \mathrm{~nm}$ obtidas em ELISA com soros da população de São João, Amapá - Março 2000

Figura 11: Distribuição das absorbâncias a $414 \mathrm{~nm}$ obtidas em ELIS com soros da população de Santo Antônio, Amapá - Março 2000 
Figura 12 : Distribuição do An. darlingi e An. albitarsis, capturados $\epsilon: m$ três capturas consecutivas no periodo de maio a outubro de 1999 na reglião do rio Matapi, Amapá.

Figura 13: Positividade do An. darlingi infectado mensalmente pelo $P$. falciparum (PFT), P.vivax (PVT), P.vivax VK247 (PKT), P.vivaxllike (PLT) e P. malariae (PMT) pelo ELISA, coletados na região do rio Matapi, Amapá, maio a outubro de 1999.

Figura 14: Positividade do An. albitarsis infectado mensalmente pelo $P$. falciparum (PFT), P.vivax (PVT), P.vivax VK247 (PKT), P.vivaxlike (PLT) e P. malariae (PMT) pelo ELISA, coletados na região do rio Matapi, Amapá, maio a outubro de 1999. 


\section{LISTA DE TABELAS}

Tabola 1 : Número de casos de malária nas Américas, 1970 1997. Fonte: PAHO 1998.

Tabela 2 :Total de amostras de sangue examinadas e o número de amostras positivas de acordo com o nivel de transmissão, 1997 Fonte PAHO 1998.

Tabola 3: Situação epidemiológica de 21 paises com programas ativos de malária, 1997. Fonte: PAHO 1998.

Tabola 4: Número de casos de malária notificados no Brasil, 199()-1998. Fonte: FUNASA 2001.

Tabola 5: Números de casos das doenças de notificação compulsćria por trimestre e coeficiente de incidência, Amapá 1999. FONTE: Governo do Estado do Amapá/Secretaria da Saúde/UVE/DE/CVS/SESA-AP, 1999

Tabela 6 - Padronização da reação de Imunofluorescência Indireta (IFI) com antígenos de formas assexuadas de P.vivax e P.falciparum para detecçāo de anticorpos da classe lgG em soros humanos.

Tabola 7. Padronização do teste de Imunofluorescência Indireta (IF I) com formas assexuadas de P.vivax e P.falciparum para deteç̧ão de anticorpos da classe IgM. Conjugado anti-lgM humano

Tabola 8 :Valores do limiar de reatividade para cinco peptídeos sintéticos, pelo emprego de 30 amostras de soros provenientes do Banco de Sangue de São Paulo.

Tabola 9: Valores do limiar de reatividade para os cinco peptídeos sintéticos, pelo emprego de 30 amostras de soros provenientes ce área endêmica de malária, coletados no estado do Amapá. 
Tabela 10 : Distribuição por faixa etária e sexo dos individuos entrevistados na regiāo do rio Matapi, Amapá, março de 2000.

Tabola 11 : Atividades econômicas desenvolvidas pela população re:sidente na região do rio Matapi, Amapá, março 2000.

Tabola 12 : Positividade pelo teste da gota espessa e esfregaço sanģuíneo com população residente nas localidades de São Raimundo de Pirativa, São João e Santo Antônio, Amapá, março 2000.

Tabola 13: Resultado das parasitemias obtidas no teste da gota espessa da população residente nas localidades de São Raimundo, São João $€$ Santo Antônio, Amapá, março 2000.

Tabela 14 : Prevalência de anticorpos da classe lgG e lgM contra anígenos de formas sangüineas (assexuadas) de $P$.vivax e $P$.falciparum para o teste de Imunofluorescência Indireta (IFI) com soros das populações cle São Raimundo, São João e Santo Antônio, estado do Amapá, março de 2000.

Tabola 16 : Prevalência de anticorpos contra peptídeos relacionados às proteínas CS de Plasmodium falciparum, Plasmodium vivax, Plasınodium malariae, P.vivax VK247 e Plasmodium vivax like com soros da localidade de São Raimundo, março de 2000.

Tabola 16 : Distribuição do Anopheles darlingi e Anopheles al'ititarsis, capturados em três capturas consecutivas no periodo de maio a outı.ubro de 1999 na região do rio Matapí, Amapá.

Tabola 17: Valores do limiar de reatividade para P.falciparum, vivax, P.malariae, P.vivax VK247 e P.vivax like, pelo emprego de 100 exemplares de An. stephensi criados em laboratório, não infectados.

Tabela 18 : Positividade do Anopheles albitarsis infectado por Plasinodium falciparum, P.vivax, P.vivax VK247, P.vivax/ike e P. malariae pelo ELISA, coletados na região do rio Matapi, Amapá no periodo de maio a out ıtro de 1999. 
Tabela 19: Positividade do An. albitarsis infectado por $P$. falciparum, F' vivax, P.vivax VK247, P.vivax/like e P. malariae pelo ELISA, coletados na região do rio Matapi, Amapá no periodo de maio a outubro de 1999. 


\section{ÍNDICE}

Fáginas

\section{INTRODUÇÃO}

$\begin{array}{ll}\text { 1.1. Histórico } & 1\end{array}$

1.2. A malária no mundo $\quad 6$

1.3. A malária nas Américas $\quad 8$

1.4. A malária no Brasil 13

1.5. A malária no Estado do Amapá $\quad 17$

1.6. Anofelinos relacionados com a transmissão da malária 20

1.7. As variantes do Plasmodium vivax 28

2. JUSTIFICATIVA 32

3. OBJETIVOS 33

3.1. OBJETIVO GERAL 33

3.2. OBJETIVOS ESPECIFICOS 33

4. MATERIAL E MÉTODOS 35

4.1. Delineamento experimental e éticos da pesquisa 35

4.2. Área de estudo 36 
4.2.1. Aspectos físicos da região

4.2.1.1. Localização

4.2.1.2. Clima

4.2.1.3. Geomorfologia

4.2.1.4. Recursos hidricos

4.2.2. Aspectos bióticos da região estudada

4.2.3.2. Saúde

4.2.3.3. Educação

4.2.3.4. Economia

4.2.3.5. População e migração 
4.3.1. Coleta das informações epidemiológicas e do sangue venoso

\subsubsection{Testes Parasitológicos}

4.3.2.1. Descrição do teste da gota espessa e do esfregaço sangüineo

\subsubsection{Testes Imunológicos com os soros humanos}

4.3.3.1. Padronização e descrição da reação de Imunofluorescência Indireta

4.3.3.2. Padronização e descrição doELISA com os soros humanos

\subsection{Estudo Entomológico}

4.4.1. Obtenção, identificação e acondicionamento dos anofelinos

4.4.2. Detecção da infecção malárica nos anofelinos

4.4.3. Padronização e descrição do ELISA com os anofelinos

4.4.3.2. Antigenos utilizados como padrão positivo e negativos e obtenção dos esporozoítas

4.4.3.3. Conjugação do anticorpo monoclonal à biotina

4.4.3.4. Determinação das concentrações ideais dos anticorpos monoclonais e do conjugado imunoenzimático 
4.4.3.5. Determinação das concentrações ideais de antigenos (proteínas recombinantes e peptídeos sintéticos)

4.4.3.6. Testes de especificidade

4.4.3.7. Determinação do limiar de reatividade do ELISA 85 com anofelinos

4.4.4. Descrição do ELISA para anofelinos

85

4.5. Métodos estatísticos

85

5. RESULTADOS

87

5.1. Resultados da população humana

5.1.1. Resultados das informações epidemiológicas

87

5.1.2. Resultados dos Testes Parasitológicos

5.1.2.1 Resultados da gota espessa e do esfregaço sangüineo

5.1.3. Resultados dos testes Imunológicos com soros

5.1.3.1. Resultados da Reação de Imunofluorescência Indireta (IFI)

5.1.3.2. Resultado do ELISA com os soros humanos 
5.2.2. Resultados da padronização do ELISA com os anofelinos

5.2.2.1. Determinação das concentrações ideais dos 104 anticorpos monoclonais e do conjugado imunoenzimático

5.2.2.2. Determinação das concentrações ideais dos 104 antígenos (proteínas recombinantes e peptídeos sintéticos)

5.2.2.3. Testes de especificidade

5.2.2.4. Determinação do limiar de reatividade no teste 105 ELISA com os anofelinos

5.3. Resultados do ELISA com os anofelinos

5.3.1. Resultados da infectividade do An. darlingi pelos 107 diferentes plasmódios

5.3.2. Resultados da infectividade do An. albitarsis pelos 109 diferentes plasmódios

6. DISCUSSÃO

7. CONCLUSÃO 
ANEXO I. Ficha de investigação epidemiológica

ANEXO II. Comprovante da aprovação do projeto na Comissão de Ética 


\section{Introdução}

\subsection{Histórico}

A malária é uma doença infecciosa causada por protozoários pertencentes ao Filo Apicomplexa, gênero Plasmodium (Marchiafava e Celli, 1885), com cerca de 120 espécies que acometem aves, répteis e maniferos. Quatro delas infectam naturalmente o homem: $P$. falciparum Welch, 1897 P.vivax (Grassi e Feletti, 1890), P. malariae (Laveran, 1881) e F'ovale, Stephens, 1922 (REY 1991).

Embora a origem da malária seja incerta, evidências históricas sugerem a sua existência desde os tempos mais remotos. A presença de febres intermitentes foi referida por diversos povos em diferentes épocas, como os relatos descritos pelos chineses por volta de 2700 a.C., em tijolos na Mesopotâmia datadas de 2000 a.C., nas descriçōes egipcias de 1570 a.C., assim como em escritos Vedas na İndia (1500 a 800 a .C.). No século IV a.C. Hipócrates, na Grécia, foi o primeiro médico a descrever a doença clinicamente e a estabelecer sua relação com as estaçōes do ano e o local onde as pessoas acometidas pela doença viviam (REY 1991; DEANE 1992).

Ao longo da história, os conhecimentos sobre a malária foram lentos Somente no século XVII, o missionário peruano Juan Lopes, em 1600 , observou que os amerindios empregavam a casca de uma árvore nativa, conhecida por "casca das febres" para fazer infusões de chá contra as febres. Em 1643, a droga conhecida como "pó dos jesuítas" foi levada para Roma pelo cardeal Juan de Lugo e usada no Hospital Santo Spiritu na cura de soldados, reis e cardeais, espalhando-se a utilização por toda a Europa. A referida árvore foi descrita por Lineu em 1742 e recebeu o nome de cinchona (Cinchvona ledgeriana). O quinino, seu principio ativo, foi isolado em 1820 em Paris por dois franceses, Joseph Caventou e Joseph Pelletier (DEANE 1988). 
No século XVIII, a forma de transmissão ainda não era conhecida pelas populações antigas que atribuiam a doença aos "miasmas", que eram as emanações dos pântanos. Dai a origem do termos malária "mal aire" do italiano, e paludismo ou impaludismo, do francês, cuja origem vem de "pallus" que significa água estagnada (REY 1991).

Avanços significativos relativos aos conhecimentos da malária surgiram a partir de 1880 quando Charles Louis Alphonse Laveran, médico do exército francês na Argélia observou pela primeira vez o agente etiológico no interior dos glóbulos vermelhos humanos, verificando pigmentos pretos nas hemácias e em órgãos necropsiados de soldados mortos pela doença. O médico inglês Ronald Ross, em 1897, trabalhando na Índia, elucidou o mecanismo de transmissão natural da doença, por meio da observação do parasita em mosquitos. Em 1889, o cientista Batista Grassi, identificou o Anopheles como sendo o transmissor da malária (KNELL 1991; DUTRA 2001).

A partir de então, iniciaram-se as primeiras medidas de controle voltadas basicamente ao estabelecimento de obras de saneamento básico, por meio de drenagem de córregos, rios e construções de aterros sanitários. Foram introduzidas com estas obras substâncias químicas formadas de compostos de arsênio, o denominado verde-paris, e derivados de petróleo nos criadouros visando à eliminação da fase larvária dos insetos (REY 1981; DUTRA 2001).

Alguns conflitos bélicos ocorridos ao longo da história exerceram influência sobre a pesquisa da malária. A necessidade de aquisição de quinino pelas tropas alemãs na Primeira Guerra Mundial incentivou o desenvolvimento de drogas sintéticas como a pamaquina (1924), mepacrina (1930) e cloroquina (1934). Outro marco na pesquisa da doença foi a síntese do composto de ação residual, dicloro-difenil-tricloroetano (DDT) ern 1942 , por Paul Muller na Suiça, de baixo custo e grande poder inseticida (DUTRA 2001; Di SANTI e BOULOS 1999). 
Com o advento do DDT, que se mostrou altamente eficiente na eliminação dos insetos transmissores, aliado à disponibilidade de drogas antimaláricas, surgiu a idéia de que a doença pudesse ser erradicada do mundo. Em 1955, o conceito de erradicação foi adotado na Assembléia Mundial de Saúde e dois anos depois foram lançadas as estratégias que seriam adotadas na Campanha Global de Erradicação da Malária. O programa de erradicação apresentou as seguintes etapas:

- Fase preparatória: procedeu-se a identificação das áreas malarigenas e dos imóveis possiveis de serem borrifados com DDT,

- Fase de ataque: constituida pela cobertura total da área em termos de diagnóstico parasitológico dos indivíduos sintomáticos, tratamento dos doentes, borrifação semestral dos imóveis com DDT e aplicação de medidas de controle nos criadouros dos mosquitos (obras de drenagem e aplicação de larvicidas),

-Fase de consolidação: esta etapa era mantida por quatro anos nas áreas cuja incidência se mantivesse em niveis baixos (um caso em 100 habitantes) e em que não fossem notificados casos autóctones,

- Fase de manutenção: iniciava-se nas áreas cuja interrup ção da borrifação com DDT nas casas tinham cessado por no mínimo três anos consecutivos e com ausência de casos de malária. Mantinham-se açōes de vigilância epidemiológica pelos sistemas de saúde locais (DUTRA 2001).

Os esforços empregados durante esta campanha contribuiram para que, no final da década de 60 houvesse diminuição de cerca de $53 \%$ da transmissão da malária em algumas áreas como Américas, Ásia, Sul e Sudeste da Europa. Infelizmente em 1970 houve recrudescimento da doença, sobretudo, pela diminuição das atividades de controle por motivos de ordem econômica, administrativa e técnico-operacional. Além dos fatores de ordem biológica como o aparecimento da resistência dos anofelinos aos inseticidas e dos plasmódios aos quimioterápicos. 
Assim, foi preciso rever as estratégias globais, substituindo-se as ações então direcionadas à erradicação por ações de controle. Nesta etapa, deu-se importância à realidade epidemiológica e social das populações locais, assim como aos fatores de ordem social, econômicos, culturais e ecológicos, além da participação ativa da população (WERNSDORFER 1980; BRUCE-CHWATT 1985).

A elevação do número de casos ocorridos em várias regiões do mundo fez com que técnicos da OMS realizassem uma Conterência Ministerial de Malária em outubro de 1992, em Amsterdã, Holanda, para elaboração de normas técnicas a serem adotadas em áreas de risco. Implantou-se a Declaração Mundial de Controle da Malária e uma Estratégia Global de Controle visando à redução da morbidade, prevenção da mortalidade, assim como diminuição do impacto sócio-econômico causado pela moléstia, com base na manutenção dos seguintes pontos (WHO 1992):

- Diagnóstico precoce e tratamento rápido,

- Planejamento e implementação de medidas preventivas e seletivas, incluindo-se o controle dos vetores,

- Deteç̧ão, controle e prevenção de epidemias,

- Reforço da capacidade local em desenvolvimento de pesquisa básica e aplicada para permitir e promover avaliações regulares da situação da malária em nivel nacional.

Em 1995, a Organização Mundial da Saúde com agências das Nações Unidas e Conselho Econômico das Nações Unidas implantaram a Estratégia Global para o período compreendido de 1995 a 2000, por intermédio da elaboração de um Plano de Ação para o Controle da Malária, cujo objetivo está centrado em: 
- Colaborar com os países no que diz respeito às prioridades e necessidades locais,

- Reforçar a capacidade local por intermédio de pesquisa operaciorial e da realização de treinamentos e reciclagens,

- Integrar as atividades do controle da malária aos demais programas da área da saúde.

O objetivo principal deste plano foi que ocorresse até o ano 2000 a redução da mortalidade da malária em $20 \%$ em relação a 1995, em 75\% dos paises endêmicos da África Subsaariana. 


\subsection{A malária no mundo}

O risco de os indivíduos contrairem a malária é bastante elevado em várias regiões mundiais, em razão de aproximadamente 2.400 milhões de pessoas viverem em áreas propicias a sua instalação. Segundo dados da OMS, a malária é endêmica em 53 paises na África, 21 nas Arnéricas, quatro na Europa, 14 na Região Leste do Mediterrâneo, oito ao Sudeste da Ásia, e nove a Oeste do Pacifico (WHO 1996a). De acordo com o local de residência, as características epidemiológicas e o número de casos, as áreas malarígenas no mundo podem estar subdivididas em:

Áreas sem transmissão, onde nunca foram detectados casos da doença, ou em áreas cuja erradicação foi estabelecida,

Áreas malarigenas, que compreendem regiōes onde a doença mantémse endêmica ao longo dos anos ou onde se conseguiu uma diminuição da incidência, porém a transmissão é mantida.

A malária é uma enfermidade que atinge as populações mais empobrecidas do planeta. Estima-se a ocorrência de 300 milhões a 500 milhões de casos clínicos e cerca de 1,5 milhões a 2,7 milhões de ijbitos a cada ano, a maioria em crianças abaixo de cinco anos de idade Aproximadamente $80 \%$ da morbidade e $90 \%$ da mortalidade da doença ocorrem na África. (WHO 1996a).

A mortalidade em razão da doença é extremamente elevada, segundo dados da OMS a malária mata uma criança a cada 30 segundos em regiöes rurais da África, onde o acesso aos serviços de saúde é deficiente. Em números absolutos, isto significa a morte de 3 mil crianças por dia. Pesquisas realizadas em Gâmbia, Gana, Quênia e Burkiná Faso demonstram que aproximadamente $30 \%$ dessas mortes poderiam ser evitadas utilizando-se medidas de controles simples como o emprego do. mosquiteiros impregnados com inseticida (WHO 2000). 
A subnotificação dos casos é um problema constante em todos os países atingidos pela malária. Um exemplo é o Afeganistão no qual, em 1991, a prevalência da doença foi de 298 mil casos notificados, porém estima-se de 2 milhões a 3 milhōes de casos por ano (WHO 1996b) . A tendência de elevação da incidência neste pais é esperada, devido ao conflito bélico que atualmente $o$ assola.

Estima-se que o número real de casos na Índia gire em torno de 18 milhōes, o que corresponderia a $40 \%$ da malária ocorrida em países não africanos, $40 \%$ dos quais pelo $P$. falciparum. No Sri-Lanka o número de casos também foi bastante alto em 1993, atingindo cerca de 360 mil casos e 1,4 milhão subnotificados. No mesmo ano, estimativas de individuos positivos e de óbitos no Camboja foram 600 mil e 10 mil, respectivamente. Outros paises como Papua-Nova Guiné, Filipinas, Ilhas Salomão, Tailândia e Vietnã apresentaram $510 \mathrm{mil}, 65 \mathrm{mil}, 126 \mathrm{mil}, 99 \mathrm{mil}$ e $156 \mathrm{mil}$, respectivamente, $71 \%$ causados pelo $P$. falciparum, o que denota a elevação da prevalência em paises não pertencentes à comunidade africana WHO 1996c).

Os prejuizos de ordem econômico-sociais atribuidos à doença foram mensurados por um grupo de pesquisadores na região subsaariana, onde se verificou que os custos empregados na área hospitalar e nas atividades de controle atingiram valores excedentes a 2 bilhões de dólares por ano WHO 2000), além do custo decorrente do absenteísmo ao trabalho e na escola, que a curto prazo são dificeis de ser avaliados, porém afetam sobremaneira as comunidades abrangidas pela doença. 


\subsection{A malária nas Américas}

A Organização Mundial da Saúde e Organização Panamericana de Saúde elaboraram nos últimos anos um Plano de Estratégia Global para o Controle da Malária (EGCM) (PAHO 1998), para ser desenvolvido nas Américas. Desse modo os países participantes estão redefinindo suas áreas malarigenas sob a base de diferentes riscos de exposição à doença que são:

- Fatores relacionados com os processos migratórios das populações para áreas de transmissão,

- Adoção de mudanças de hábitos por parte da população de risco, seja em nivel individual ou coletivo visando à proteção contra os vetores,

- Acesso da população ao diagnóstico e tratamento precoces.

Dados epidemiológicos de 1997 demonstram que a população estimada das Américas naquele ano era de 794 milhões de habitantes, dos quais 307 milhões viviam em áreas ecologicamente propícias à transmissão da doença (tabela 1). Dentre os 37 paises membros da OMS/OPS, 21 apresentaram transmissão ativa da doença. São eles: Equador, Argentina Belize, Bolivia, Brasil, Colômbia, Costa Rica, República Dominicana, El Salvador, Guiana Francesa, Guatemala, Guiana, Haiti, Honduras, México, Nicarágua, Panamá, Paraguai, Peru, Suriname e Venezuela (PAHO 1998) 
Tabela 1

Número de casos de malária nas Américas, 1970 - 1997

(EM MILHARES)

HABITANTES EM ÁREAS ECOLOGICAMENTE PROPICIAS PARA A TRANSMISSÃO DE MALÁRIA

RISCO DE TRANSMISSÃO DE MALÁRIA

\begin{tabular}{cccccc}
\hline ANO & Alto & Médio & Baixo & TOTAL & $\begin{array}{c}\text { TOTAL DE } \\
\text { CASOS DE } \\
\text { MALÁRIA }\end{array}$ \\
\hline 1970 & 80,770 & 59,807 & 40,518 & 181,257 & 505,819 \\
1971 & 81,306 & 60,396 & 43,644 & 185,492 & 513,544 \\
1972 & 86,634 & 61,645 & 42,016 & 190,448 & 524,774 \\
1973 & 87,969 & 61,915 & 45,535 & 195,528 & 535,109 \\
1974 & 91,527 & 63,130 & 46,042 & 200,755 & 544,865 \\
1975 & 99,405 & 61,834 & 44,633 & 205,872 & 555,676 \\
1976 & 101,068 & 61,205 & 48,813 & 211,086 & 565,249 \\
1977 & 104,567 & 60,373 & 50,610 & 215,550 & 576,942 \\
1978 & 105,611 & 54,808 & 59,734 & 220,153 & 587,004 \\
1979 & 113,092 & 55,989 & 57,280 & 226,361 & 600,263 \\
1980 & 114,620 & 58,656 & 58,087 & 231,366 & 610,021 \\
1981 & 117,042 & 62,256 & 59,962 & 239,260 & 627,375 \\
1982 & 118,338 & 64,941 & 62,028 & 245,307 & 635,954 \\
1983 & 119,175 & 63,182 & 66,970 & 249,327 & 639,212 \\
1984 & 124,408 & 64,496 & 68,372 & 257,276 & 659,535 \\
1985 & 124,086 & 68,659 & 67,092 & 259,837 & 665,777 \\
1986 & 116,143 & 103,500 & 43,717 & 263,371 & 662,983 \\
1987 & 117,310 & 108,633 & 42,334 & 268,277 & 672,384 \\
1988 & 124,250 & 109,927 & 46,048 & 280,225 & 703,385 \\
1989 & 126,666 & 113,419 & 45,309 & 285,394 & 715,994 \\
1990 & 120,980 & 110,139 & 47,481 & 278,600 & 698,199 \\
1991 & 143,239 & 71,381 & 66,504 & 281,124 & 721,256 \\
1992 & 134,089 & 51,974 & 103,885 & 289,948 & 725,564 \\
1993 & 202,329 & 46,225 & 41,030 & 289,584 & 739,561 \\
1994 & 160,947 & 37,409 & 32,967 & 231,323 & 763,305 \\
1995 & 169,643 & 42,454 & 36,881 & 248,978 & 774,712 \\
1996 & 210,519 & 46,277 & 41,332 & 298,128 & 786,055 \\
1997 & 221,341 & 30,822 & 54,358 & 306,521 & 793,582 \\
\hline
\end{tabular}

Fonte: PAHO (1998). 
A partir da análise do número de casos notificados nas Américas em 1997, indicado na Tabela 2, verifica-se que o Brasil apresentou o maior número absoluto, equivalente a $36,0 \%$ do total, correspondente a praticamente toda a região Andina, que totaliza $43,0 \%$ dos casos. 
TABELA 2

TOTAL DE AMOSTRAS DE SANGUE EXAMINADAS E O NÚMERO DE AMOSTRAS POSITIVAS DE ACORDO COM O NIVEL DE RISCO DE TRANSMISSÃO,1997

\begin{tabular}{|c|c|c|c|c|c|c|c|c|c|c|}
\hline \multirow[b]{2}{*}{$\begin{array}{l}\text { PANSESE } \\
\text { TERRTORLOS }\end{array}$} & \multicolumn{2}{|c|}{ TOTAL } & \multicolumn{2}{|c|}{$\begin{array}{l}\text { BAIXO RISCO } \\
\text { DE TRANSMISSÃO }\end{array}$} & \multicolumn{2}{|c|}{$\begin{array}{l}\text { MOOERADO RISCOO } \\
\text { DE TRANSMISSAO }\end{array}$} & \multicolumn{2}{|c|}{$\begin{array}{l}\text { ALTO RISCO } \\
\text { DE TRANSMISSAOO }\end{array}$} & \multicolumn{2}{|c|}{$\begin{array}{l}\text { AREAS SEM } \\
\text { MALARIA }\end{array}$} \\
\hline & $\begin{array}{l}\text { AMOSTRAS } \\
\text { EXAMINADAS }\end{array}$ & POSITIVAS & $\begin{array}{l}\text { AMOSTRAS } \\
\text { EXAMINADAS }\end{array}$ & POSITIVAS & $\begin{array}{l}\text { AMOSTRAS } \\
\text { EXAMINADAS }\end{array}$ & POsitivas & $\begin{array}{l}\text { AMOSTRAS } \\
\text { EXAMINADAS }\end{array}$ & POSITIVAS & $\begin{array}{l}\text { AMOSTRAS } \\
\text { EXAMINADAS }\end{array}$ & Positivas \\
\hline $\begin{array}{l}\text { CANADA } \\
\text { CUBAA }\end{array}$ & 171763 & 1006 & . & : & - & . & . & & 171763 & 1006 \\
\hline CHLE & 10 & 10 & : & : & : & . & : & . & 10 & 10 \\
\hline BARBADOS & & 4 & - & . & . & . & . & & 10 & r \\
\hline DOMNNICA & 10 & & . & . & . & - & . & $r$ & . & \\
\hline GRANADA & & & - & . & . & . & . & . & . & \\
\hline GUADALUPE & & 3 & - & . & . & - & . & - & - & 3 \\
\hline JAMAICA & 102 & 10 & . & . & : & $\because$ & : & . & 102 & 10 \\
\hline MARTINICA & & & - & . & . & - & . & - & . & \\
\hline PORTO RICO & . & - & - & - & - & . & . & - & . & \\
\hline SANTA LUCA & & & - & . & . & 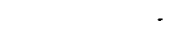 & & 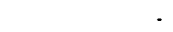 & & \\
\hline TRINIDADE E TOBAGO & 17.228 & 6 & . & . & . & - & & - & 17.228 & \\
\hline ESTADOS UNIDOS & 1.265 & 1265 & . & . & . & . & . & - & 1.265 & $1.265^{\circ}$ \\
\hline URUGUAL & & & - & - & - & . & & . & & \\
\hline ILHAS VRGENS(EUA) & 190378 & 2338 & & $\overline{0}$ & & & & 0 & 190368 & 2339 \\
\hline MEXICO & $\begin{array}{r}1950.935 \\
\end{array}$ & 5046 & 284.189 & $\frac{5}{31}$ & 552936 & 737 & 1.144610 & 4.277 & 190.300 & $\frac{2339}{1}$ \\
\hline BELICE & 26.598 & 4014 & 0 & 0 & 7669 & 486 & 18.929 & 3.528 & . & \\
\hline COSTA RICA & 155925 & 4.712 & 2809 & 55 & 134.120 & 2.757 & 18996 & 1.711 & & 189 \\
\hline EL SALVADOR & 166.895 & 2719 & 24.830 & 231 & 25552 & 209 & 104.889 & 2.244 & 11.624 & 35 \\
\hline GUATEMALA & 140113 & 32099 & 24.469 & 2.534 & 47.963 & 9.063 & 67.198 & 20.378 & 483 & 124 \\
\hline HONDURAS & 300063 & 65863 & 38995 & 3.101 & 20.381 & 3.620 & 240687 & 59.142 & & \\
\hline $\begin{array}{l}\text { NICARAGUA } \\
\text { PANAMA }\end{array}$ & $\begin{array}{l}410132 \\
193853\end{array}$ & 42819 & $\begin{array}{l}35.280 \\
42232\end{array}$ & 1.079 & 87.673 & 5.669 & 287.179 & 36.071 & - & \\
\hline $\begin{array}{l}\text { PANAMA } \\
\text { HAITI }\end{array}$ & $\frac{193853}{69.853}$ & $\begin{array}{r}505 \\
1877\end{array}$ & & & 151.621 & 432 & & & $\because$ & \\
\hline REP DOMINICANA & 446874 & 816 & 378190 & 408 & $68684^{\circ}$ & $408^{\circ}$ & & & : & \\
\hline GULANA FRANCESA & 42631 & 3195 & . & 81 & 1501 & 12 & 26.207 & 2.902 & - & 200 \\
\hline GULANA & 229710 & 32103 & - & & & . & . & & - & \\
\hline $\begin{array}{l}\text { SURINAME } \\
\text { BRASI }\end{array}$ & $\begin{array}{r}94.508 \\
1896382\end{array}$ & $\begin{array}{r}11323 \\
392976\end{array}$ & & 23661 & & $87511^{\circ}$ & 1072963 & 289670 & 487 & 134 \\
\hline $\begin{array}{l}\text { BRASIL } \\
\text { BOINYA }\end{array}$ & $\frac{1.869382}{141804}$ & $\frac{392976}{51478}$ & $\frac{393998}{0}$ & 23.007 & $\frac{401934}{33193}$ & $\frac{87511}{12056}$ & $\frac{1.072 .963}{10.611}$ & $\frac{281.670}{39.422}$ & 486 & 134 \\
\hline $\begin{array}{l}\text { BOLIVA } \\
\text { COLOMBLA }\end{array}$ & $\begin{array}{l}141804 \\
582309\end{array}$ & $\begin{array}{r}51.488 \\
180.898\end{array}$ & 15613 & 924 & $\begin{array}{l}3.233 \\
62.237\end{array}$ & $\begin{array}{l}12.056 \\
22.156\end{array}$ & 504.459 & $\begin{array}{r}307.422 \\
157.824\end{array}$ & : & : \\
\hline EOUADOR & 174692 & 16365 & 6225 & 1.454 & 74.963 & 4.869 & 93.504 & 10.052 & & \\
\hline PERU & 1528004 & 183740 & 60327 & 2.661 & 406818 & 25243 & 1.057 .973 & 115.435 & 2886 & 401 \\
\hline VENEZUELA & 271989 & 22400 & 9582 & 558 & 30230 & 1608 & 231.588 & 20.212 & 589 & 22 \\
\hline ARGENTINA & 9684 & 592 & 4033 & 83 & & & 5.610 & 468 & & \\
\hline PARAGUA & 41667 & 567 & 3558 & 6 & 1.758 & $3^{3}$ & 36.111 & 553 & 250 & 5 \\
\hline 21 PAISES SUBTOTAL & 8847.621 & 1073107 & 1324330 & 36934 & 2078.433 & 176.829 & 5.019 .514 & 755.889 & 16319 & 1.111 \\
\hline TOTAL & 9037999 & 1075.445 & 1.324330 & 36.934 & 2078.433 & 176.829 & 5.019 .514 & 755.889 & 206687 & 3.450 \\
\hline
\end{tabular}

\footnotetext{
FONTE: PAHO (1998)
} 
TABELA 3

\begin{tabular}{|c|c|c|c|c|c|}
\hline \multicolumn{6}{|c|}{$\begin{array}{l}\text { SITUAÇÃO EPIDEMIOLÓGICA DE } 21 \text { PAISES } \\
\text { COM PROGRAMAS ATIVOS DE MALÁRIA, } 1997\end{array}$} \\
\hline \multicolumn{2}{|c|}{ PESSOAS EM RISCO } & \multicolumn{4}{|c|}{ ESPECIES PARASITARIAS } \\
\hline $\begin{array}{l}\text { PAISSES POR } \\
\text { SUB-REGIĀO } \\
\text { GEOGRÁFICA }\end{array}$ & $\begin{array}{l}\text { POPULAÇÃO } \\
\text { EM ÁREAS } \\
\text { COM MALARIA* }\end{array}$ & EXAMINADAS & $\begin{array}{c}P . \\
\text { falciparum } \\
\text { e associada }\end{array}$ & P. vivax & P. malariae \\
\hline MEXXICO & 20.392 & 1.666 .746 & 65 & 4.949 & 0 \\
\hline BELICE & 230 & 26.598 & 123 & 3.888 & 0 \\
\hline COSTA RICA & 932 & 153.116 & 40 & 4.428 & 0 \\
\hline EL SALVADOR & 2.257 & 127.244 & 2 & 2.431 & 0 \\
\hline GUATEMALA & 4.958 & 115.161 & 859 & 28.690 & 0 \\
\hline HONDURAS & 3.831 & 261.068 & 741 & 62.021 & 0 \\
\hline NICARAGUA & 2.221 & 373.982 & 1.805 & 48.556 & 0 \\
\hline PANAMÁ & 315 & 136.628 & 167 & 265 & 0 \\
\hline HAIT $*$ & 7.395 & 69.853 & 18.877 & 0 & 0 \\
\hline REP. DOMINICANA & 227 & 68.684 & 408 & 0 & 0 \\
\hline GUIANA FRANCESA & 14 & 27.708 & 2.180 & 591 & 130 \\
\hline GUIANA & 449 & 229.710 & 18.238 & 11.865 & 0 \\
\hline SURINAME & 36 & 94.508 & 9.251 & 1.125 & 245 \\
\hline BRASIL & 7.468 & 1.474 .897 & 90.146 & 277891 & 1.144 \\
\hline BOLIVIA & 3.166 & 141.804 & 5.381 & 46.097 & 0 \\
\hline COLÓMBIA & 14.629 & 566.696 & 66.094 & 113.781 & 105 \\
\hline EQUADOR & 2.944 & 168.467 & 2.854 & 12.057 & 0 \\
\hline PERU & 11.112 & 1.464 .791 & 52.913 & 124.324 & 35 \\
\hline VENEZUELA & 926 & 261.818 & 4.063 & 17693 & 64 \\
\hline ARGENTINA & 245 & 5.610 & 0 & 592 & 0 \\
\hline PARAGUAI & 1.440 & 37.849 & 1 & 555 & 0 \\
\hline TOTAL & 85.187 & 7.472 .938 & 274.208 & 761.799 & 1.723 \\
\hline
\end{tabular}

" POPULAÇĀo (MILHARES)- ÁREAS COM RISCO MOdERAdo E ALTO

* NÃO HÁ INFORMAÇÃo dISPONIVEL PARA 1997

Fonto: PAHO 1998. 


\subsection{A malária no Brasil}

Nas décadas de 20 e 30 , iniciou-se o emprego das primeiras medidas mais sistematizadas de controle da malária no Brasil. As ações envolviam aplicação de inseticidas de ação não residual (piretro) nas moradias, incentivo ao uso de mosquiteiros pela população exposta, telagem das residências e o uso dos antimaláricos atebrina e plasmoquina (FUNASA 1995).

Em 1930, ocorreu um surto epidêmico de malária na cidade de Natal, no Rio Grande do Norte, quando esta foi infestada pelo An. gambiae, proveniente da África. Em poucos dias gerou-se uma grande epidemia. Foi então criado o Serviço de Malária do Nordeste, que por meio de um intenso trabalho eliminou o anofelino do pais. Graças ao bom desempenho deste órgão, em 1941 foi inaugurado o Serviço Nacional de Malária, que visava ao controle da endemia em todo o território nacional.

A criação deste órgão foi extremamente importante nesta época, visto que a prevalência estimada na década de 1940 passou de 6 milhöes de casos anuais para 52.469 casos em 1970 (MINISTÉRIO DA SAÚDE 1992)

Seguindo a tendência mundial, houve uma significativa elevação da incidência da malária no Brasil a partir da década de 70 , coincidindo com o periodo em que foram elaboradas propostas governamentais para explorar os recursos naturais da região amazônica, na tentativa de sua integrá-la às demais regiōes brasileiras (MARQUES e GUTIERREZ 1994)

A região amazônica brasileira corresponde ao principal pólo de disseminação da doença nas Américas, suas alterações ao longo dos anos propiciaram profundas modificaçōes nos padrões de distribuição populacional e introduziram doenças restritas a determinadas áreas (McGREVY et. al 1989; CASTILLA et. al 1993; SAWYER 1993).

Com a intensificação dos processos migratórios, nos quais grandes contingentes populacionais dirigiram-se para a região Norte do paıs em 
busca de melhores condiçōes econômicas, a maioria atraida pelos projetos de colonização, agropecuários, mineração, extração de madeira, construçāo de hidrelétricas e demais atividades relacionadas com o desmatamento da floresta, o aumento de casos da doença foi inevitável nos últimos anos (TAUIL 1984; MARQUES 1986, 1987, 1993; CAMARGO et. al 1994).

Em 1970, foi criada a Superintendência de Campanhas de Saúde Pública (SUCAM) para dar continuidade a programas de erradicaçāo de várias doenças, incluindo-se a malária. A instituição passou a atuar em todas as regiōes malarígenas do País, que foram então subdivididas em áreas de erradicação a longo e curto prazos.

A área de erradicação a longo prazo correspondia à Amazônia Legal com cerca de 5 milhōes $\mathrm{km}^{2}$, ocupava aproximadamente $60 \%$ do território nacional. Esta área abrangia os atuais Estados do Acre, Amapá, Amazonas, Mato Grosso, Pará, Rondônia, Roraima e Tocantins e parte ocidental do Maranhão. A área de erradicação a curto prazo compreendia os Estados de Alagoas, Bahia, Ceará, Espírito Santo, Goiás, Minas Gerais, Paraiba, Paraná, Pernambuco, Piaui, Rio de Janeiro, Rio Grande do Norte, Santa Catarina, Sāo Paulo e Sergipe (TAUIL 1986; MARQUES 1993).

Atualmente, o programa de controle da malária é realizado pela Fundação Nacional da Saúde (FUNASA) e tem como objetivo geral a redução da morbidade e mortalidade. A FUNASA segue o Plano de Intensificação das Ações de Controle de Malária na Amazônia Legal (FUNASA 2000), estratégia que vem sendo aplicada em 254 municipios da região amazônica brasileira e visa atingir os seguintes objetivos:

- Redução da morbidade da doença em niveis sustentáveis,

- Redução do surgimento de epidemias localizadas,

- Redução da gravidade da doença e, consequentemente, do número de óbitos, 
- Manutenção de açōes articuladas voltadas às áreas indigenas juntamente com os Distritos Sanitários Indigenas,

- Manutenção das açōes conjuntas com o Departamento de Engenharia de Saúde Pública da FUNASA,

- Introdução de controle seletivo de vetores em todos os municipios,

- Garantia de fornecimento de diagnóstico e tratamento precoce à população. Tais procedimentos atuam diretamente em sua cadeia de transmissão, interrompendo o ciclo de reprodução sangüinea do parasita, responsável pelas manifestações clinicas, e eventuais complicaçōes da doença. Impedem ainda as recidivas e a eliminação dos gametócitos,

- Manutenção do Sistema de Informação em malária,

- Eliminação da transmissão em áreas urbanas.

A proposta governamental inclui a descentralização das açöes de controle, onde os recursos financeiros são transferidos diretamente do nivel federal aos fundos estaduais e municipais, estabelecendo um fluxo mais rápido, para evitar a descontinuidade das ações (FUNASA 1999). No atual plano, as estratégias de atuação são divididas em duas áreas:

Área amazónica: onde o controle se impõe por meio de mecanismos ágeis e flexiveis, com atividades capazes de identificar, delinitar e caracterizar as inúmeras situações de transmissão existentes na área; estabelecendo os niveis de controle e os objetivos a serem perseguidos em cada caso. Além desses pontos, o programa prevê o desenvolvimento da capacidade de articulação com instituiçōes públicas e/ou privadas e outros setores do governo.

Área oxtra-amazónica: visa ao estabelecimento e manutençāo das atividades de vigilância definindo a vulnerabilidade e a receptividade das 
diferentes regiões e garantindo diagnóstico e tratamento precoces aos pacientes.

Tabela 4. Número de casos notificados de malária no Brasil, no periodo de 1990 a 1998

\begin{tabular}{|c|c|c|c|c|c|c|c|c|c|c|}
\hline \multicolumn{11}{|c|}{ Espécies } \\
\hline & \multicolumn{2}{|c|}{ P.vivax } & \multicolumn{2}{|c|}{ P.falciparum } & \multicolumn{2}{|c|}{$P v+P f$} & \multicolumn{2}{|c|}{ P.malariae } & \multicolumn{2}{|c|}{ Total } \\
\hline Ano & Número & $\%$ & Número & $\%$ & Número & $\%$ & Número & $\%$ & Número & $\%$ \\
\hline 1990 & 328.184 & 55,0 & 248.207 & 44,3 & 21 & 0,00 & 3.984 & 0,7 & 560.396 & 100,0 \\
\hline 1991 & 323.175 & 59,6 & 214.988 & 39,7 & 108 & 0,02 & 3.656 & 0,7 & 541.927 & 100,0 \\
\hline 1992 & 331.870 & 57,5 & 241.271 & 41,8 & 158 & 0,03 & 3.799 & 0.7 & 577.098 & 100,0 \\
\hline 1993 & 307.060 & 63,4 & 173.259 & 35,8 & 212 & 0,04 & 3.604 & 0,8 & 484.135 & 100,0 \\
\hline 1994 & 370.354 & 65,1 & 193.057 & 34,0 & 146 & 0,02 & 4.754 & 0,8 & 568.311 & 100,0 \\
\hline 1995 & 361.559 & 63,9 & 199.531 & 35,3 & 765 & 0,10 & 3.891 & 0,7 & 565.746 & 100,0 \\
\hline 1996 & 311.208 & 70,4 & 128.418 & 28,9 & 1.573 & 0,40 & 2.850 & 0,6 & 444.049 & 100,0 \\
\hline 1997 & 305.493 & 75,4 & 95.439 & 23,6 & 1.077 & 0,30 & 3.042 & 0,7 & 405.051 & 100,0 \\
\hline 1998 & 364.435 & 77,2 & 102.719 & 21,8 & 1.512 & 0,30 & 3.226 & 0,7 & 471.892 & 100,0 \\
\hline
\end{tabular}

Fonte: FUNASA 2001.

O número de casos positivos de malária no ano 2000 foi 611.042 , sendo 522.683 provenientes da região Norte. Dentre os estadcs que compõem esta região, os que apresentaram maior prevalência foram o Pará (278.203), seguido pelo Amazonas (96.026) e Rondônia (54.074) (FUNASA 2001).

A região Nordeste apresentou 79.386 casos, sendo o Maranhão o responsável por 78.817 casos. No Sudeste, foram notificados 647 casios, no Sul, 230 e no Centro-Oeste, 8.036 casos. 


\subsection{A malária no Estado do Amapá}

O Governo do Amapá, por meio de projetos de sustentabilidade da economia local, busca um equilibrio entre os aspectos econômicos, sociais e ambientais. A agregação desses valores às atividades agricolas e florestais com a pesca e a mineração fortalecem a dinâmica local e regional, gerando e distribuindo os recursos financeiros e fixando a população nos locais de origem.

Apesar desta prática, a morbidade, das diversas doenças incluindo-se a malária, é elevado, conforme demonstram os dados de 1999 (Tabela 5). Entre as principais doenças de notificação compulsória que acometeram a população do Estado, a malária foi a que apresentou a maior prevalência.

A figura 1 mostra a evolução do número de casos de inalária notificados no Estado do Amapá, Brasil, 1985-2000. 
TABELA 5

NÚMEROS DE CASOS DAS DOENÇAS DE NOTIFICAÇÃO COMPULSÓRIA POR TRIMESTRE E COEFICIENTE DE INCIDÉNCIA, AMAPÁ, 1999.

\begin{tabular}{|c|c|c|c|c|c|c|}
\hline AGRAVOS & $1^{\circ} \mathrm{Trim}$ & $2^{\circ}$ Trim & $3^{\circ}$ Trim & $4^{\circ}$ Trim & TOTAL & C.I. \\
\hline AIDS & 13 & 9 & - & 5 & 27 & 6,13 \\
\hline COLERA & - & - & - & - & - & - \\
\hline COQUELUCHE & 4 & 4 & 5 & 3 & 16 & 3,63 \\
\hline DENGUE & - & - & - & - & - & - \\
\hline DIFTERIA & . & - & - & - & - & - \\
\hline DST & 706 & 838 & 584 & 640 & 2.768 & 629,40 \\
\hline DOENÇA DE CHAGAS & - & - & - & - & - & - \\
\hline FEBRE AMARELA & - & - & - & - & - & - \\
\hline FEBRE TIFOIDE & 5 & 20 & 7 & 2 & 34 & 7,73 \\
\hline HANSENIASE & 45 & 42 & 35 & 31 & 153 & 34,79 \\
\hline HEPATITE A & 127 & 248 & 151 & 147 & 673 & 153,03 \\
\hline HEPATITE B & 10 & 16 & 26 & 33 & 85 & 19,32 \\
\hline HEPATITE C & 4 & 11 & 21 & 36 & 72 & 16,37 \\
\hline HEPATITE NĀO ESPECIFICA & 6 & 15 & 16 & 27 & 64 & 14,55 \\
\hline LEPTOSPIROSE & 88 & 57 & 193 & 100 & 438 & 99,59 \\
\hline LTA & 66 & 189 & 94 & 132 & 481 & 109,37 \\
\hline MALÁRIA & 2.939 & 2.049 & 8.962 & 13.180 & 27.130 & 6168,97 \\
\hline MENINGITE POR HEMOFILOS & 4 & 2 & 2 & 1 & 9 & 2,04 \\
\hline MENINGITE MENINGOCICA & 1 & - & 2 & - & 3 & 0.68 \\
\hline MENINGITE PNEUMONIA & - & 2 & 2 & 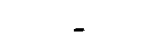 & 4 & 0,90 \\
\hline MENINGITE NÃO ESPECIFICA & 6 & 9 & 6 & 2 & 23 & 5,22 \\
\hline POLIOMIELITE & - & - & - & - & - & - \\
\hline RAIVA HUMANA & - & - & - & - & - & - \\
\hline RUBEOLA & 6 & 26 & 60 & 66 & 158 & 35,92 \\
\hline RUBEOOLA CONGÉNITA. & - & - & 3 & - & 3 & 0,68 \\
\hline SARAMPO & - & - & - & - & - & - \\
\hline TÉTANO ACIDENTAL & - & 2 & 1 & 3 & 6 & 1,36 \\
\hline TETTANO NEONATAL & - & - & - & 1 & 1 & 0,22 \\
\hline TUBERCULOSE & 62 & 63 & 44 & 39 & 208 & 47,29 \\
\hline ACS. PI ANIM. PEÇON. & 86 & 63 & 51 & 54 & 254 & 57,75 \\
\hline TOXOPLASMOSE & 3 & 7 & 7 & 6 & 23 & 5,22 \\
\hline
\end{tabular}

FONTE: Governo Do Estado do Amapá/Secretaria da

Saúde/UVE/DE/CVS/SESA-AP 1999.

Não houve registro de casos (-).

L.T.A. (Leishmaniose tegumentar americana).

DST (Doenças sexualmente transmissivel).

Acs. Pl anim. Peçon ( acidentes por animais peçonhentos). 
Figura 1

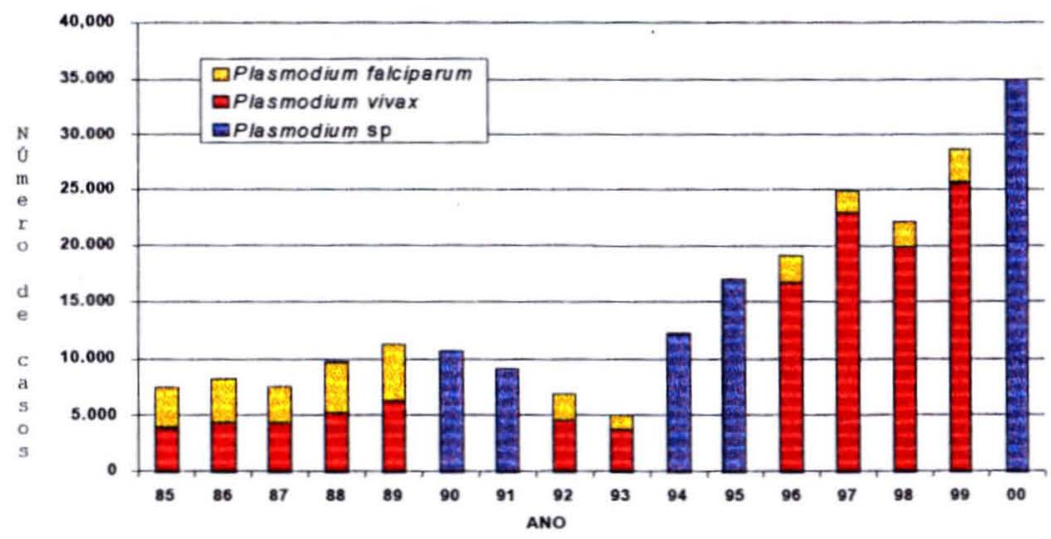

Figura 1: Evolução do número de casos de malária notificados no Estado do Amapá, Brasil, 1985-2000. Fonte: (MS/FUNASA 2000).

Figura 2

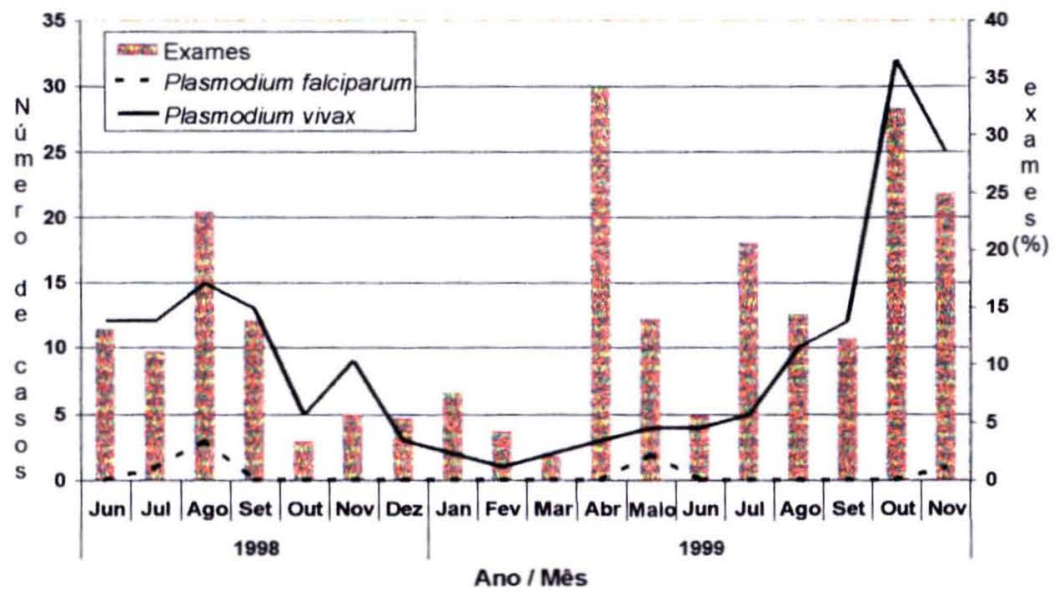

Figura 2. Número de casos notificados, por espécie na área de estudo Junho 1998 - Novembro 1999 Fonte: FUNASA MS. 2000 (gráfico elaborado por Jaco Voorham) 


\subsection{Anofelinos relacionados com a transmissão da malária}

A transmissão da doença de forma natural para o homem ocorre pela picada do mosquito pertencente à ordem Díptera, família Culicidae, subfamilia Anophelinae, tribo Anophelini, do gênero Anopheles. Na natureza são encontradas aproximadamente 400 espécies, porém cerca de 60 são consideradas boas vetoras da malária (BRUCE-CHWATT 1985; CONSOLI e OLIVEIRA 1994).

No continente africano o An. (Mys) gambiae, sensu strictu Giles, 1902 e o An. (Mys) funestus Giles, 1900 são os principais transmissores da malária, ao lado de espécies pertencentes ao complexo gambiae, como o An. arabiensis, Patton, 1905 (DAVID 1991; SNOUNOU et. al 1993; COLLINS e BESANSKY 1994; CONSTANTINE et. al 1996; ELISSA et. al 1999).

Cabe ressaltar, conforme foi mencionado anteriormente, que aproximadamente $90 \%$ dos casos da malária mundial ocorrem na África, totalizando valores entre $\mathbf{2 7 0}$ milhões e $\mathbf{4 8 0}$ milhões de pessoas acometidas pela doença a cada ano. Assim, é primordial a implementação de estudos entomológicos nos paises africanos.

Em relaçāo à distribuição anofélica nas Américas, GUIMARÃES (1997), relata os seguintes subgêneros Anopheles. Meigen: Nyssorhynchus (28 espécies), Kerteszia (12 espécies), Lophopodomyia (6 espécies), Stethomyia (5 espécies) e Anopheles. (46 espécies). As espécies capazes de transmitir a malária pertencem aos Subgêneros: Nyssorhynchus, Anopheles e Kerteszia

O An. darlingi Root, 1926, é a espécie mais amplamente encontrada desde o México até a Argentina, nas áreas de baixas altitudes como: no leste dos Andes, Colômbia, Venezuela, Bolívia, Peru, Paraguai, Argentina, Brasil e Guianas; no oeste dos Andes, somente na Colômbia. Nas áreas centro-americanas, foi encontrado em Belize, Honduras e Guatemala (CONSOLI e OLIVEIRA 1994). 
Outra espécie importante é An. (Nys) aquasalis Curry, 1932, presente numa faixa que vai do municipio de Peruíbe em São Paulo até a Costa Rica, beirando o Oceano Atlântico. Daí segue até o Golfo de Guaiaquil, no Equador, no Oceano Pacífico. A espécie é encontrada nas Antilhas, em Trinidad e Tobago (CONSOLI e OLIVEIRA 1994).

Destacam-se An. (Nys) albimanus Wiedemann, 1821, encontrado no México, Belize, Costa Rica, El Salvador, Guatemala, Honduras, Nicarágua, Panamá, Colômbia, República Dominicana e Equador; An. (Nys) nuneztovari Galbadón, 1940, está presente na Colômbia e Venezuela; An. (Nys) pseudopunctipennis Theobald, 1901, na Bolivia, Panamá, Nicarágua, México, Peru, e Argentina e An. (Ker) bellator Dyar e Knab, 1906, na Venezuela, nas Guianas e Trinidad e Tobag, sendo também importantes vetores da endemia (RODRIGUEZ et. al 1992; RUBIO-PALIS 1992a; LOYOLA et. al 1993; SEGURA 1998).

No Brasil, foram encontradas 54 espécies pertencentes ao subgênero Anopheles. Meigen: Nyssorhynchus, Kerteszia, Lophopodomyia, Stethomyia e Anopheles. Somente os Nyssorhynchus e Kerteszia são capazes de transmitir a malária humana (GUIMARĀES 1997).

Apesar da distribuição dos anofelinos ter sido relatada por vários autores ao longo dos anos DEANE (1948, 1986, 1988, 1989); TADEI et. al (1988, 1993); LOURENÇO-DE-OLIVEIRA et. al (1989); OLIVEIRAFERREIRA et. al (1990); ROCHA e MASCARENHAS (1994); ROCHA (1996); ROSA- FREITAS (1998), entre outros, faz-se necessária a realização de uma carta anofélica para o mapeamento das regiões malarígenas brasileiras.

Em relação ao subgênero Kerteszia, as principais espécies encontradas no Brasil são An. (Kerteszia) cruzii, Dyar e Knab 1908 e An. (Kerteszia) bellator Dyar e Knab, 1906b, são espécies neotropicais, com ampla distribuição na costa brasileira.

An. (Kerteszia) cruzii é antropofilico de hábitos predominantemente exofílicos, encontrado em ambientes da mata. Apresenta atividade ao longo 
An. (Kerteszia) cruzii è antropofilico de hábitos predominantemente exofilicos, encontrado em ambientes da mata. Apresenta atividade ao longo das 24 horas do dia, com picos nos períodos crepusculares e suas formas larvárias desenvolvem-se em águas depositadas nos áxeis das bromeliáceas (FORATTINI et. al 1987; TUBAKI 1993). A espécie é o único vetor natural conhecido de malária simiana no Brasil e nas Américas, que veicula $\circ P$. brasilianum e $\circ P$. simium, tendo sido também encontrado infectado com o $P$. vivax clássico e com o $P$. vivax VK 247 (DEANE 1986; BRANQUINHO et. al 1996).

No subgênero Nyssorhynchus, as espécies encontradas infectadas com plasmódios no Brasil são: An. darlingi Root 1926, que apresenta elevado grau de antropofilia (TADEl et. al 1986; 1987), acentuada adaptação às diferentes condiçōes ambientais (TADEI 1987a; TADEI e SANTOS 1987), além de grande capacidade de reprodução em diferentes hábitats (DEANE 1986). Desde a década de 30 , a espécie vem sendo considerada a responsável pela deflagração da endemia no território nacional, sendo altamente susceptivel aos plasmódios (CONSOLI e OLIVEIRA 1994).

An. aquasalis Curry, 1932, apresenta preferência por águas com altos teores de salinidade, além de ser geralmente encontrado em coleções hidricas paradas de pequeno ou médio porte, transitórias ou semipermanentes, ensolaradas ou parcialmente sombreadas, características estas presentes em áreas de baixadas litorâneas (CONSOLI e OLIVEIRA 1994). SUCUPIRA et. al (2001) no Estado do Pará, encontraram positividade de $1,19 \%$ da espécie para P.falciparum, P.vivax 210 e $P$.vivax VK247

An. albitarsis Lynch-Arribálzaga, 1878, é um complexo formado por quatro espécies, incluindo An. deaneorum, Rosa Freitas (1989), An. albitarsis sensu strictu, Lynch-Arribálzaga (1878); An. marajoara Galvão e Damasceno 1942b, e An. albitarsis sp (ROSA- FREITAS et. al 1990; WILKERSON et. al 1995). 
Este anofelino apresenta grandes variações moleculares e/ou bioquímicas, além de comportamentais que podem acarretar enorme heterogeneidade em termos de capacidade vetorial (DEANE 1986; KLEIN et. al 1991a,b;1990; CONSOLI e OLIVEIRA 1994; FORATTINI et. al 1994 ROSA-FREITAS et. al 1998; SANTOS 2001).

Outras espécies pertencentes ao subgênero Nyssorhynchus que vêm sendo incriminadas como potencialmente vetoras da malária são $A n$. oswaldoi, Peryassú (1922), An. nuneztovari, Galbaldon (1940) e An triannulatus, Neiva e Pinto (1922). Estas espécies apresentam variaçōes comportamentais que podem exercer influências diretas em termos de capacidade vetorial, sendo até 0 momento consideradas espécies secundárias na transmissão da malária no Brasil (ARRUDA et. al 1986; DEANE 1986; LOURENÇO- DE- OLIVEIRA et. al 1989; OLIVEIRAFERREIRA et. al 1990; CONSOLI e OLIVEIRA 1994; BRANQUINHO et. al 1996; ROSA-FREITAS 1998; PÓVOA et. al 2001).

Rotineiramente, a técnica usada para a verificação da infecção de anofelinos por plasmódios é o exame direto da glândula salivar e do estômago, seguida da observação dos esporozoítas ou oocistos, por microscopia. Esta metodologia apresenta algumas características que dificultam sua realização em larga escala, tais como:

- Baixa sensibilidade,

- A impossibilidade de definição da espécie de plasmódio envolvida na transmissão da malária,

- A necessidade de dissecar os anofelinos mortos recentemente, o que exige execução do exame em locais próximos aos da captura, que muitas vezes não apresentam infra-estrutura laboratorial adequada,

- Ser a técnica laboriosa. 
A partir da existência de anticorpos monoclonais especificos obtidos por imunização de camundongos com os peptídeos sintéticos das diferentes espécies de plasmódios, tornou-se possivel a realização dos testes imunoenzimáticos (ELISA) e imunorradiométricos (IRMA) para detectar a infecção em anofelinos pois, além de apresentarem alta sensibilidade, especificidade e reprodutibilidade nos resultados, são feitos com maior rapidez e possibilitam o processamento dos espécimes conservados, para posterior processamento em locais que apresentem uma infra-estrutura laboratorial melhor elaborada.

No que diz respeito à incriminação vetorial de uma determinada espécie, o emprego de metodologias mais sensiveis e especificas para verificar a positividade dos Plasmodium nos anofelinos, contribui para uma análise mais acurada sobre estimativas de risco de transmissão, quando associadas aos demais parâmetros entomológicos.

Algumas espécies foram reconhecidas como potencialmente vetoras da malária a partir da década de 80 com o advento dos testes imunorradiométricos (IRMA) e imunoenzimáticos (ELISA), como An. nuneztovari, An. oswaldoi, An. triannulatus, An. brasiliensis, An. mediopunctatus e An. deaneorum (ARRUDA et. al 1986; DEANE 1988; BRANQUINHO et. al 1993; OLIVEIRA-FERREIRA et. al 1990; KLEIN et. al 1991a; KLEIN et. al 1991b).

O estudo pioneiro no Brasil empregando ELISA, para a incriminação vetorial, foi realizado por ARRUDA et. al (1986), no Estado do Pará. Entre os 9.040 anofelinos examinados, os autores encontraram o An. darlingi e An. oswaldoi infectados com $P$. falciparum e An. albitarsis, An. triannulatus, An nuneztovari, An. darlingie An. oswaldoi infectados com $P$. vivax.

Em trabalhos realizados pelo nosso grupo em alguns municipios do Acre, testamos 3.056 exemplares de anofelinos pelo ELISA, em que ) An. 
oswaldoi foi incriminado como o principal potencial vetor da doença. Esta espécie apresentou $85,4 \%$ de prevalência total e positividade de $3,4 \%$ para o $P$. falciparum, $2,3 \%$ para $P$. vivax, $1,3 \%$ para o $P$. vivax variante VK247 e $0,4 \%$ para $P$. malariae; seguida pelo An. deaneorum com $11,8 \%$ de prevalência e positividade de $2,9 \%$ para $P$. falciparum, $0,3 \%$ para $P$. vivax e 0,9\% para $P$. vivax VK247 (BRANQUINHO et. al 1993).

Em relação à distribuição dos vetores no Estado do Amapá, CERQUEIRA 1961, encontrou as seguintes espécies anofélicas no Município de Macapá: An. darlingi, An. albitarsis, An. aquasalis, An. triannulatus, An. brasiliensis, An. nuneztovari, An. oswaldoi, An. peryassui e An. mediopunctatus.

SEGURA 1998 realizou estudo entomológico em três localidades periurbanas do municipio de Macapá, Amapá. Pelo ELISA, o autor encontrou positividade distribuída em cinco espécies: An. marajoara (1,61\%), An. darlingi (0,61\%), An. brasiliensis (2,80\%), An. mattogrossensis (17,39\%) e An. peryassu (0,05\%).

Entre 106 anofelinos, 90 foram identificados como An. marajoara, dois An. darlingi, nove An. brasiliensis, três An. mattogrossensis e dois An. peryassui Foram positivos para $P$. vivax VK247: 25 (18 An. marajoara, três An. darlingi, quatro An. brasiliensis. Para P. malariae, oito (quatro An. marajoara, três An. brasiliensis e um An. mattogrossensis), para $P$. vivax e cinco (três An. marajoara, um An. brasiliensis e um An. peryassui), infectados com $P$. falciparum. A autora concluiu que An. (Nys) marajoara é o principal vetor de malária vivax nas áreas estudadas.

PÓVOA et. al 2001 conduziram uma pesquisa em seis localidades do Municipio Serra do Navio, Estado do Amapá. Dentre os 3.053 anofelinos capturados, foram identificadas 15 espécies, sendo as mais prevalentes (96,4\% do total): An. albitarsis s. I (64,4\%), An. braziliensis, (16,7\%), An. nuneztovari $(9,5 \%)$, An. triannulatus $(5,8 \%)$. 
Os avanços metodológicos empregados na entomologia têm possibilitado uma identificação mais precisa das espécies de plasmódios que infectam os anofelinos, assim como o estabelecimento de espécies críticas (ZIMMERMAN 1992; WILKERSON et. al 1995).

Além dos testes imunológicos, algumas metodologias foram desenvolvidas para a verificação da infecção por plasmódios em anofelinos. A reação em cadeia da polimerase (PCR), executada com primers espécieespecificos ou gênero-específicos são capazes de detectar dez esporozoítas e um único oocisto no material analisado (TASSANAKAJON et. al 1993, SNOUNOU et. al 1993).

Recentemente foi padronizado 0 ensaio imunocromatográfico VecTest $^{\mathrm{TM}}$ Malária, capaz de detectar a proteina circunsporozoita do $P$. vivax 210, $P$. vivax VK 247 e $P$. falciparum. Em testes de laboratório, esta técnica apresentou sensibilidade de $1,0 \mathrm{ng} / \mathrm{ml}$ para a proteína CS das três espécies de plasmódios. Desde que bem padronizado, o ensaio será muito adequado em pesquisas de campo, pois uma das principais vantagens è a rapidez na sua execução, cerca de 15 minutos, além de não necessitar de equipamentos sofisticados.

Até o momento, foram realizados estudos preliminares testando o VecTest $^{\mathrm{TM}}$ em 13 paises na África, Ásia e Américas com diferentes situações epidemiológicas para a malária, mostrando sensibilidade e especificidade comparáveis ao ELISA (Navix-inc.com/intro.html).

Dadas as particularidades da região amazônica, que apresenta diferentes situações epidemiológicas, é de extrema importância uma adequada caracterização do comportamento dos vetores, o conhecimento dos parasitas circulantes, aspectos da população humana e do ambiente.

O desenvolvimento de metodologias capazes de verificar a infecção de plasmódios nos vetores que apresentem alta sensibilidade, especificidade, reprodutibilidade, facilidade na execução e baixo custo, 
aliados aos estudos de biologia e comportamento e ao emprego de técnicas moleculares para a definição de espécies críticas pode contribuir para o desenvolvimento de modelos mais apropriados no entendimento da dinâmica de transmissão da doença. 


\subsection{As variantes do Plasmodium vivax}

Em relação aos plasmódios, grandes avanços nas pesquisas foram alcançados por intermédio da demonstração da existência de antígeno específico de esporozoítas denominado proteina circunsporozoita (CS), capaz de distinguir entre as várias espécies de Plasmodium (NUSSENZWEIG e NUSSENZWEIG 1985). Esta proteina é estágioespecifica com epitopos repetitivos imunodominantes (ZAVALA et. al 1986).

O seqüenciamento da proteina CS de Plasmodium e a clonagem dos genes correspondentes evidenciaram uma região central com uma seqüência de aminoácidos repetitivos constituída de 373 aminoácidos, com uma região central de 19 repetições consecutivas do nonapeptídeo Asp-ArgAla-Asp/Ala-Gly-GIn-Pro-Ala-Gly (DRAD/AGQPAG), totalizando $49 \%$ da proteína. A seqüência não repetitiva do gene, apresenta grande homologia com os genes do $P$. cynolmogi e com $P$. knowlesi, causadores de malária simiana (ARNOT et. al 1985).

Por alguns anos, acreditou-se que a proteina CS se mantivesse conservada entre as distintas espécies de plasmódios e entre os diferentes isolados geográficos, contudo, para $P$. vivax, foram descritas duas variantes da proteina CS, denominadas de $P$. vivax VK247 e $P$.vivax-like humano (ROSENBERG et. al 1989; QARI et. al 1993).

A variante P.vivax VK 247 foi descrita por ROSENBERG et. al (1989) ao estudarem pacientes da Tailândia com infecção pelo $P$. vivax. Neste estudo verificou-se a presença de uma heterogeneidade fenotipica na região repetitiva da proteina CS. Ao tentar reagir esporozoitas, isolados de anofelinos alimentados com sangue de alguns desses pacientes, constatouse que eles não foram reconhecidos por anticorpos monoclonais dirıidos contra diferentes cepas de $P$. vivax e de outras espécies de malária humana e simiana. P. vivax VK247 difere em 6/9 aminoácidos [ANGA(G/D)(N/D)QPG] contidos na mesma seqüência encontrada em todas as proteinas CS descritas anteriormente [GDRA(D/A)GQPA] (ARNOT et al 1985) 
QARI et. al (1993), por intermédio de metodologia similar à empregada na descrição da variante VK247, ao pesquisarem sangue de pacientes da Papua Nova Guiné, usando oligonucleotideos específicos, encontraram um parasita morfologicamente semelhante ao $P$. vivax, porém apresentando a região repetitiva da proteína CS idêntica à encontrada no P.simiovale [APGANQ(E/G)GGAA], um plasmódio localizado no macaco Rhesus muito semelhante ao $P$. ovale humano.

Esta nova variante foi denominada $P$. vivax like/ $P$. simiovale e tem sido alvo de discussões sobre questões evolutivas do parasita. Informações mais precisas poderão elucidar se o $P$. vivax like é um membro da espécie $P$. vivax ou um novo parasita de malária humana (OLIVEIRA et. al 1995).

Alguns trabalhos foram realizados para verificação da distribuição global do $P$. vivax VK247 e ou $P$. vivax like como os de COCHRANE et. al (1990) com soros provenientes da Índia e do Brasil, os de KAIN et. al 1991, em população africana, os de KAIN et. al (1992), com soros do México, Papua Nova Guiné e Afeganistão, os realizados por WIRTZ et. al (1992); KAIN et. al $(1991,1992)$ em população da Tailândia, entre outros.

No Brasil, ARRUDA et. al (1996) realizaram um importante estudo sorológico sobre a distribuição das variantes em populações residentes nos Estados do Pará, Rondônia e Mato Grosso, onde se verificou alta positividade para anticorpos antiesporozoitas do $P$ vivax-like. Dentre os soros analisados, Rondônia apresentou a maior porcentagem (85\%), seguida do Mato Grosso (70\%) e Pará (61\%). As positividades para as variantes VK 247 também foram extremamente elevadas: $71 \%$ no Pará. $76 \%$ em Rondônia e $76 \%$ no Mato Grosso. 
Ainda na bacia amazônica nos Estados do Amapá, Rondônia e Pará, um interessante trabalho foi realizado por MACHADO (1997), cujo objetivo principal foi verificar a distribuição do $P$.vivax VK210 ( $P$. vivax clássico), $P$. vivax VK 247 e $P$. vivax like, por meio da amplificação do gene codificador da proteína CS, procurando-se correlacionar o tipo de $P$. vivax com os sinais e sintomas da doença. Os resultados estão apresentados abaixo, e foram concordantes com os de ARRUDA et. al (1996) nos Estados de Rondônia e Pará.

\begin{tabular}{|c|c|c|c|}
\hline & P. vivax VK247 & P. vivaxAlike & P. vivax VK 210 \\
\hline Amapá & $71,4 \%$ & $71,4 \%$ & $85,7 \%$ \\
\hline Rondónia & $69,7 \%$ & $60,6 \%$ & $84,8 \%$ \\
\hline Pará & $60,0 \%$ & $42,5 \%$ & $87,5 \%$ \\
\hline
\end{tabular}

Em relação aos sinais e sintomas, os autores não verificaram nenhuma caracteristica diferente da encontrada na literatura. As implicaçōes clínicas das variantes precisam ser melhor estudadas (MACHADO e PÓVOA 2000; RODRIGUES et. al 2000).

Um inquérito soro-epidemiológico foi conduzido no Estado do Pará por ARRUDA et. al (1998), no qual se verificou a presença do $P$.vivax VK247 e P.vivax like em soros de populações indigenas que foram trabalhadas pela autora cerca de 12 anos atrás, mostrando que as variantes coexistem com $P$. vivax clássico, no mínimo ao longo deste periodo. 
O estudo da distribuição do P.vivax VK 247 e P.vivax like na população humana e anofélica foi feito no Estado do Acre por KREMSNER et. al (1992); BRANQUINHO et. al (1993) e MARRELLI et. al (1998). Embora tenham sido realizadas nas mesmas localidades, as coletas não ocorreram ao mesmo tempo.

A suscetibilidade do P.vivax nos anofelinos foi estudada por GONZALEZ-CERON et. al (1999), que por intermédio de demonstração in vitro de colônias de An albimanus perceberam serem estas mais suscetiveis ao $P$. vivax VK210 do que ao $P$. vivax VK247; e An. pseudopunctipennis mais suscetiveis ao $P$. vivax VK247 do que ao $P$. vivax VK210 (clássico).

Recentemente os estudos de RODRIGUEZ et. al (2000) confirmaram estes resultados, mostrando que An. albimanus é o principal vetor VK210 enquanto $A n$. pseudopunctipennis pode transmitir ambas as espécies. As implicações clínicas das variantes de $P$. vivax não estão inteiramente compreendidas (MACHADO e PÓVOA 2000; RODRIGUEZ et. al 2000).

A literatura atual apresenta vários trabalhos sobre as variantes do $P$. vivax, porém a maioria restringe-se a sua distribuição na população humana ou anofélica de forma independente. Existe uma carência de estudos cientificos que analisem a relação entre os parâmetros de transmissão entomológica com a incidência da malária, para fornecer maiores subsidios cientificos a um melhor planejamento das ações de controle. 


\section{Justificativa}

A malária é um problema de grande magnitude e de difícil resolução. Assim, é plenamente justificável a escolha desta doença por parte da Organização Mundial da Saúde, como uma de suas grandes prioridades (WHO 2000).

A heterogeneidade das situações maláricas ocorridas no Brasil fez com que as estratégias do programa de controle da endemia adotadas pela Fundação Nacional da Saúde fossem adaptadas às realidades locais, substituindo definitivamente a política de critério único de controle por ações regionalizadas.

Assim, para que esta meta seja efetivamente atingida, é de extrema importância uma caracterização adequada do comportamento das espécies vetoras, dos parasitas circulantes, da população humana e do ambiente, nos diferentes ecossistemas brasileiros.

Estudos de malária em populações ribeirinhas no Brasil são escassos, assim como estudos sobre a fauna culicidiana da Região Amazônica e a sua potencialidade de transmissão. Desta forma, estudos desta natureza visam a um melhor entendimento da dinâmica local de transmissão.

A introdução de metodologias mais sensiveis, especificas e de fácil realização no diagnóstico humano ou nos vetores aos programas de controle favorecem o desenvolvimento de um modelo mais eficiente ao entendimento da dinâmica de transmissão da doença. Além disso, maiores iinformações sobre a distribuição das espécies vetoras em determinada área, aliada ao conhecimento da potencialidade de transmissão do parasita, podem igualmente contribuir para a execução e aperfeiçoamento dos programas adotados pelas autoridades responsáveis pelo controle da endemia no Brasil. 


\section{Objetivos}

\subsection{Objetivo Geral}

Estudar os fatores de transmissão da malária nas localidades de São Raimundo de Pirativa, Santo Antônio e São João situadas no Estado do Amapá, buscando caracterizar o nivel de endemicidade da doença, obtendo dados que esclareçam pontos não conhecidos sobre a dinâmica de transmissão local e fornecendo, assim, subsídios para o planejamento mais adequado de medidas de controle da endemia nessa região.

\section{Objetivos especificos}

1. Verificar a ocorrência de infecção pesquisando-se o parasita no sangue periférico da população por meio do esfregaço sangüineo e da técnica da gota espessa;

2. Verificar a ocorrência de anticorpos contra formas assexuadas (sangüineas) de Plasmodium vivax e Plasmodium falciparum, por meio de reação de Imunofluorescência Indireta (IFI);

3. Verificar a ocorrência de anticorpos em soros da população pelo método imunoenzimático (ELISA), empregando peptídeos sintéticos correspondentes à região repetitiva da proteína CS de Plasmodium falciparum, Plasmodium malariaelP.brasilianum; Plasmodium vivax "clássico"; Plasmodium vivax VK247, Plasmodium vivax-like humanol P. simiovale: 
4. Estudar a distribuição das espécies de anofelinos na época de estudo;

5. Determinar 0 índice de infecção nos anofelinos pelo ELISA utilizando anticorpos monoclonais dirigidos contra a porção repetitiva especifica da proteina circunsporozoita (CS) do Plasmodium falciparum, Plasmodium malariae; Plasmodium vivax "clássico", Plasmodium vivax VK247 e Plasmodium vivax-like humano/P.simiovale;

6. Verificar eventuais associações entre os resultados obtidos nos estudos parasitológico, sorológico e de infecção de anofelinos com a ocorrência de malária; 


\section{MATERIAL E MÉTODO}

\subsection{Delineamento experimental e aspectos éticos da pesquisa}

Este projeto foi aprovado pelo Comitê de Ética em Pesquisa da Faculdade de Saúde Pública da Universidade de São Paulo-COEP em Sessão Ordinária de 18/4/2000, de acordo com os requisitos da Resolução CNS/196/96 sob o número 283 (Anexo 2).

Inicialmente os participantes foram esclarecidos no que diz respeito aos objetivos, riscos e benefícios da pesquisa, assim como sobre os procedimentos aplicados para a coleta das amostras de sangue da população local e dos dados epidemiológicos. Neste estudo a participação dos indivíduos foi condicionada a seu consentimento informado e envolveu autorização dos pais no caso de menores de idade.

Os pacientes com resultado negativo foram devidamente informados e os que apresentaram resultado positivo receberam 0 tratamento recomendado pelo Ministério da Saúde sob prescrição da médica infectologista Dra. Júlia Maria da Silva Voorham, da Secretaria do Estado da Saúde do Amapá. 


\section{2. ÁREA DE ESTUDO}

\subsubsection{Aspectos físicos da região}

"Nas terras do Amapá, as águas circulam em imensos caudais. O mar avança pelos leitos dos rios. A mistura das águas faz a beleza da terra. A festa aquática é anunciada pela pororoca. O Oceano Atlántico e o Rio Araguari se combinam em ondas que chegam a $5 m$ de altura, com muito barulho. Maré alta e cheia do rio, na época das chuvas, provocam o fenômeno, melhor observado entre abril e junho" (in :Lista Tolefónica do Amapá 1996 p. 10)

\section{Um pouco da história do Municipio}

Com o nome de Capitania da Costa do Cabo, a área correspondente ao atual Estado do Amapá foi doada em 1637 ao português Bento Manuel Parente, que a defendeu de duas invasões, uma inglesa e outra holandesa, ainda no mesmo século. Naquela época os limites territoriais não apresentavam contornos fisicos definidos, o que só veio a acontecer em 1713 pelo Tratado de Utrecht, no qual foram estabelecidas as fronteiras entre o Brasil e a Guiana Francesa, limites estes que não foram respeitados pelos franceses (SANTOS 1998).

Os primeiros colonizadores da região foram casais de açorianos que chegaram à Costa de Macapá, como era então chamado o canal norte do Rio Amazonas, em 1751, onde se estabeleceram. Colonizadores franceses, holandeses, irlandeses e ingleses mantinham relações comerciais com os indios havia algum tempo e apresentavam uma politica de expansão 
territorial em toda a região, que era considerada pelos portugueses como de sua propriedade. Isso causava constantes ameaças de perda do território, exigindo de Portugal medidas práticas de segurança e de controle. Desse modo, os portugueses construiram uma rede de fortificaçōes para garantir o domínio lusitano no extremo norte do Brasil e seus limites das incursōes (SANTOS 1998).

No inicio do século XIX, após a formação do território, houve um intenso desenvolvimento da região causado pelas descobertas das potencialidades econômicas da área, oriundas da exploração do ouro e da extração da borracha, cujos preços estavam em ascensão no comércio internacional. Em conseqüência do desenvolvimento econômico, iniciaramse as crescentes disputas territoriais, deflagrando-se a invasão francesa, em maio de 1895.

A posse da região pelo Brasil ocorreu em janeiro de 1900 pela incorporação do território ao Estado do Pará, com o nome de Araguarı e, em 1943, passou à administração do governo federal, chamando-se, então, Amapá nome originado de uma árvore, o amapazeiro que produz um leite muito usado pelo caboclo no tratamento de doenças pulmonares (AMAPAGE 2000)

Com a implementação da economia local em 1945 pela descoberta de grandes jazidas de manganês, ocorreu uma nova divisão territorial na qual toda a região situada ao norte do Rio Cassiporé formou o municipio do Oiapoque. Esta área foi posteriormente desmembrada, constituindo $\circ$ municipio de Calçoene.

Após a criação do Estado do Amapá em 5 de outubro de 1988 e a área de livre comércio nos municipios de Macapá e Santana, em 1991, o Estado passou a ser um novo pólo de migração na Região Amazônica. 


\subsubsection{Localização}

O Estado do Amapá está localizado na porção nordeste do Norte do Brasil, entre $4^{\circ}$ de latitude Norte e $1^{\circ}$ de latitude Sul e entre $50^{\circ}$ e $54^{\circ}$ de longitude Oeste. Apresenta uma área de $143.453,7 \mathrm{~km}^{2}$, o que equivale a $3,95 \%$ da regiāo Norte e $1,65 \%$ do território nacional. A extensão fronteiriça do Estado é de $2.392 \mathrm{~km}$, sendo $707 \mathrm{~km}$ equivalentes às fronteiras internacionais com a Guiana Francesa $(655 \mathrm{~km})$ e com o Suriname $(52 \mathrm{~km})$. As fronteiras nacionais estabelecem-se com o Estado do Pará $(1.093 \mathrm{~km}) \mathrm{e}$ com o Oceano Atlântico (598 km - IBGE 1997).

O Estado faz limite ao norte com a Guiana Francesa, a nordeste com o Suriname, a oeste com o Rio Amazonas e Estado do Pará. O pico culminante do Estado é a Serra do Tumucumaque, com 500 metros sobre o nivel do mar, localizada a noroeste do Estado (Governo do Estado do Amapá 2000). O estado é constituido pelos 16 municipios abaixo relacionados:

Amapá: seus distritos são Amapá e Sucuriju, limita-se com os municipios de Macapá, Calçoene, Ferreira Gomes Pracuúba, Tartarugalzinho, Cutias e Oceano Atlântico.

Amapari: limita-se com o Oiapoque, Laranjal do Jari, Mazagão, Porto Grande, Ferreira Gomes, Ảgua Branca do Amapari.

Calçoene: é formado por dois distritos: Cunani e Lourenço, limita-se com o Amapá, Oiapoque, Pracuúba, Água Branca do Amapari, Ferreira Gomes e com o Oceano Atlântico.

Cutias: limita-se com Tartarugalzinho, Amapá, Macapá e Ferreira Gomes.

Ferreira Gomes: limita-se com Macapá, Calçoene, Pracuúba, Tartarugalzinho, Cutias, Água Branca do Amapari e Porto Grande. 
Itaubal: limita-se com Macapá e Oceano Atlântico.

Laranjal do Jari: possui um distrito que é Laranjal do Jari, limita-se com Mazagão, Oiapoque, Guiana Francesa, Suriname e Amapari.

Macapá: está dividido em quatro distritos: Macapá, Bailique, Fazendinha e São João. Macapá limita-se com os municipios de Amapá, Santana, Ferreira Gomes, Cutias e Porto Grande.

Mazagão: possui três distritos: Mazagão, Mazagão Velho e Carvão, limita-se com Santana, Laranjal do Jari, Guiana Francesa, Amapari e o Rio Amazonas.

Oiapoque: apresenta os distritos Oiapoque, Clevelância e Vila Velha, limita-se com Calçoene, Laranjal do Jari, Guiana Francesa, Amapari, Água Branca do Amapari e Oceano Atlântico.

Porto Grande: limita-se com Macapá, Ferreira Gomes Amapari, Mazagão e Santana.

Pracuúba: limita-se com Calçoene, Amapá, Tartarugalzinho e Ferreira Gomes.

Santana: possui quatro distritos: Santana, Igarapé do Lago, tha de Santana e Igarapé da Fortaleza, limita-se com Macapá, Mazagão e Porto Grande.

Serra do Navio: limita-se com o Oiapoque, Calçoene Ferreira Gomes e Amapari.

Tartarugalzinho: possui o distrito de Tartarugalzinho limitando-se com Amapá, Ferreira Gomes, Pracuúba e Cutias.

Vitória do Jari: limita-se com Laranjal do Jari e Mazagão. 
A capital do Estado é Macapá, um porto fluvial situado ao norte do Rio Amazonas. Ocupa uma área de $6.562,4 \mathrm{~km}^{2}$, a uma altitude de 16,5 metros. É a única capital brasileira à margem esquerda do Rio Amazonas cortada pela linha do equador. O nome Macapá é uma variação de Macapa-ba, que significa "estância das macabas", um fruto gorduroso originário da macabeira, uma palmeira nativa da região.

Em 1758, no dia 04 de Fevereiro, foi fundada a Vila de São José de Macapá. Um século depois, em 06 de setembro de 1856, a Vila veio a receber foros de cidade. O termo Macapá é uma variação de Macapaba, que na linguagem indigena quer dizer "estância de Macabas" ou "lugar de abundância de Bacaba", que é uma fruta regional da qual se extrai um vinho tipico. Antes do nome Macapá, o primeiro nome oficial dado às terras foi Nueva Andaluzia, em 1544, pelo então rei da Espanha, Carlos V. (in: Portal da Amazônia 03 de Fevereiro de 2001, p 24)

Escolhemos para este estudo uma área florestal inundada, situada ao longo do Rio Matapi, constituida por três localidades pertencentes ao município de Santana: São Raimundo do Pirativa, Santo Antônio e São João. $O$ acesso até as comunidades se dá a partir de Macapá por estrada até o município de Santana e de lá de barco até a localidade de São Raimundo (cerca de $3 \mathrm{~km}$ ), em seguida São João (cerca de $5 \mathrm{~km}$ ) e finalmente Santo Antonio (cerca de $10 \mathrm{~km}$ ). A população das três localidades é totalmente ribeirinha.

No que diz respeito ao padrão habitacional da população, as moradias são constituídas por palafitas de madeira, das quais $85 \%$ apresentam dois cômodos e as demais, 3 cômodos. Nestas condições vivem em média de quatro a cinco pessoas. Um dos cômodos é usado como dormitório para a 
família e o outro é usado como cozinha. As casas apresentam paredes incompletas e são isoladas umas das outras.

Não há registro sobre o número exato de casas e de moradores desta região. A líder comunitária estima que habitem cerca de 400 moradores nas três localidades. 


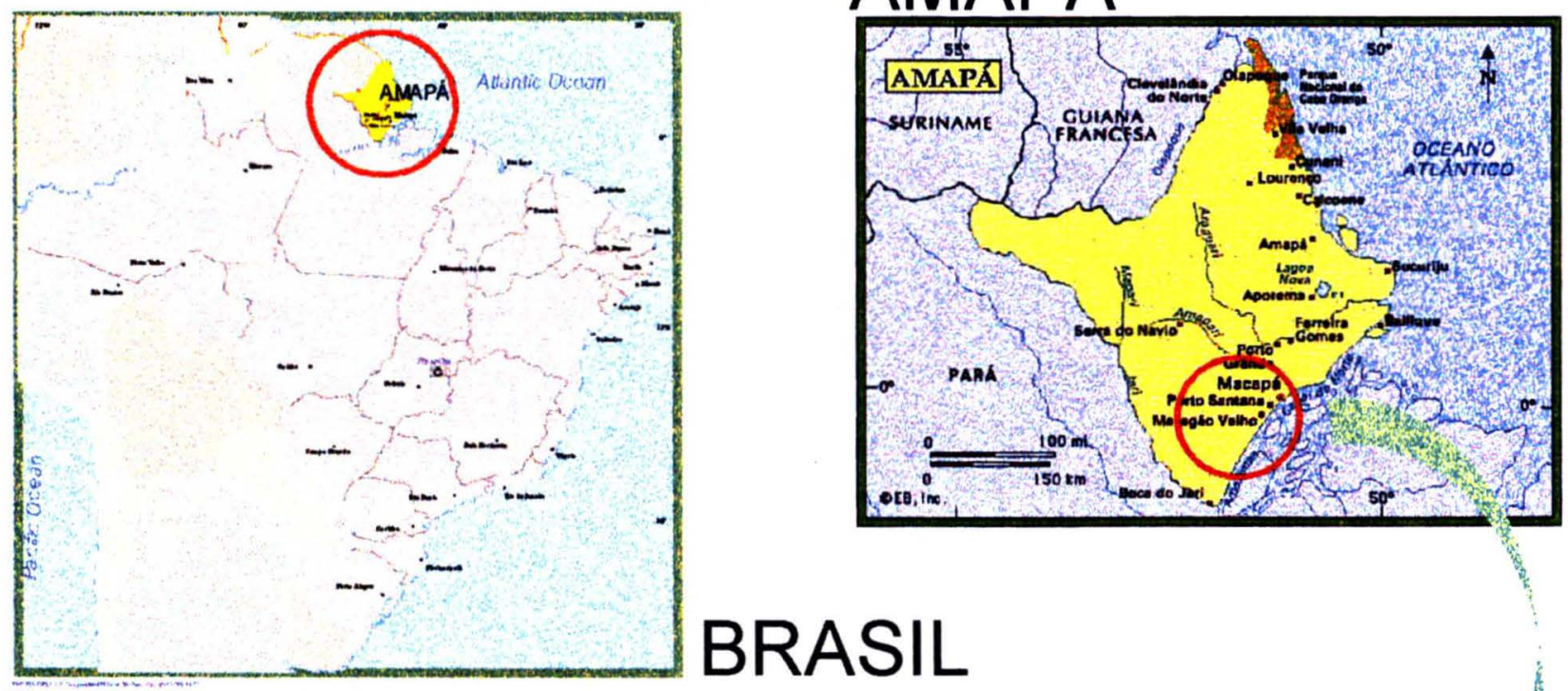

\section{AMAPÁ}

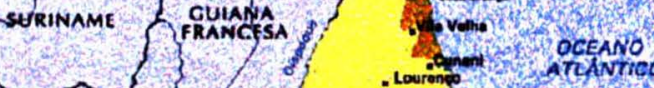

Santo Antonio

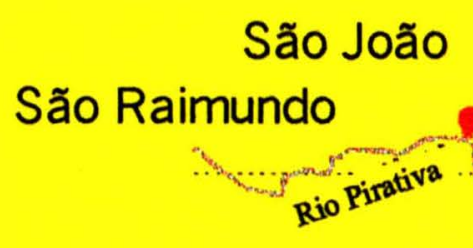

$1000 \mathrm{~m}$

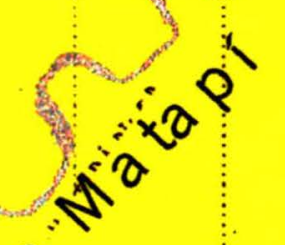

\section{Região do Rio Matapí}




\subsubsection{Clima}

O clima predominante é o equatorial superúmido com temperaturas máximas e mínimas aproximadas de $36^{\circ} \mathrm{C}$ e de $20^{\circ} \mathrm{C}$. A temperatura máxima absoluta é atingida entre 17 horas e 19 horas, e a minima ocorre ao alvorecer, entre as 5 horas e 7 horas (SUDAM 1994)

Durante o ano, duas estaçōes são definidas: o inverno, que se caracteriza pelas fortes descargas fluviais desde fins de dezembro até agosto, e o verão, com predominância dos ventos alisios, de setembro a dezembro. A estação das chuvas dá-se entre os meses de março, abril e maio, apresentando indice pluviométrico médio mensal de $2.112,9 \mathrm{~mm}^{3}$. A época de seca estende-se de setembro a novembro, com índice pluviométrico médio mensal de $177,8 \mathrm{~mm}^{3}$. O regime pluviométrico diverge de localidade para localidade em razāo da umidade relativa do ar, que é de aproximadamente $85 \%$, e sofre influências do mar e da floresta (GEOCITIES 2000).

\subsubsection{Goomorfologia}

Do ponto de vista do relevo, o Estado é formado por três unidades morfológicas pouco acidentadas constituidas por: Planalto Cristalino na porção norte do Estado, contendo numerosas extensōes de colinas e morros, denominados de cristas montanhosas, como a Serra do Tumucumaque, Serra Lombard, Serra Estrela, Serra da Agaminuara ou Uruaitu, Serra do Noucoru, Serra do Navio, Serra das Mungubas, Serra da Pancada, Serra do Iratapuru, Serra do Acapuzal, Serra Culari, Serra Aru, entre outras; Planicies Litorâneas, formadas por terrenos baixos e alagadiços e Planícies Aluviais presentes nos baixos e médios cursos dos rios (GOVERNO DO ESTADO DO AMAPÁ 2001). 


\subsubsection{Recursos Hídricos}

O Estado é formado por uma malha extensa de rios totalizando $143.453,7 \mathrm{~km}^{2}$, dos quais $39 \%$ pertencem à bacia amazônica e o restante à bacia do Atlântico Sul. Os rios mais longos são o Jari, o principal afluente do Amazonas; o Araguari, maior rio do interior do Estado, e o Oiapoque, que faz fronteira com a Guiana Francesa (GEOCITIES 2000).

Um fenômeno natural encontrado na região é a pororoca, que conjuga a beleza e a violência advindas do encontro das águas do mar com as do Rio Araguari. Sua ocorrência deve-se à elevação súbita das águas na foz, provocada pelo encontro das marés ou de correntes contrárias, constituindose em um obstáculo que as impede de seguir o percurso natural. Ao ultrapassar esse obstáculo, as águas correm rio adentro em alta velocidade, atingindo alturas de três a seis metros. O fenômeno acontece na foz do Rio Araguari, na ilha do Bailique, no Canal do Inferno da llha de Maracá e em várias áreas insulares, durante os meses de janeiro a maio. Os indios do baixo Amazonas chamam a pororoca de poroc-poroc, que significa destruidor.

"A pororoca prenuncia a enchente. Alguns minutos antes de chegar, há uma calmaria, um momento de silêncio. As aves se aquietam e até o vento parece parar de 'soprar'. É ela que se aproxima. Os caboclos já sabem e rapidamente procuram um lugar seguro como enseadas ou mesmo os pontos mais profundos dos rios para aportar suas embarcações seguras de qualquer dano, pois a canoa que estiver na 'baixa-mar', onde ela bate furiosa e barulhenta, levando árvores das margens, abrindo furos, arranca, vira, leva consigo."

(in:http://www.jandleo.vila.bol.com.br/amapa/amapa.htm). 
Os rios Calçoene e Maracá também apresentam grande importância local, cheios de cachoeiras e corredeiras, possuem enorme variedade de peixes, em que se destaca, em particular, o Tucunaré muito apreciado pela população local (GEOCITIES 2000).

A energia hidrelétrica é gerada pela Eletronorte, empresa estatal federal que administra o sistema com $75 \%$ da capacidade instalada; em decorrência disso, os custos para o consumidor são extremamente elevados. O município de Macapá consome aproximadamente $72 \%$ da energia gerada e o de Santana consome $18 \%$, sendo a classe de consumo mais importante a residencial, que utiliza a metade da energia gerada. Já as atividades comerciais consomem 17\% em Macapá e 13\% em Santana. Nos últimos três anos, o consumo de energia aumentou em $70 \%$ no Estado, graças ao fornecimento para várias comunidades rurais e periféricas da capital. 


\subsubsection{Aspectos bióticos da região estudada}

\subsubsection{Flora}

A área alterada do Estado do Amapá, incluindo-se desmatamentos e outras formas de interferência humana, é de $2.795,5 \mathrm{~km}^{2}$, o que corresponde a 1,9\% do território nacional (GOVERNO DO ESTADO DO AMAPÁ 1998).

O Estado apresenta uma vegetação florestal extremamente diversificada, constituida por uma cobertura vegetal com o domínio de formações campestres compostas pelos cerrados e campos de várzea (inundáveis ou aluviais) e pelas formaçōes florestadas compostas pela Floresta de Várzea, inundada apenas nas cheias dos rios, Floresta de Terra Firme, bastante densa e não atingida pelas inundações, e os Campos, que podem ser inundáveis ou limpos, predominando, porém, os campos inundáveis.

A Floresta de Terra Firme é o ecossistema mais importante do Amapá. Ocupa extensa área, de aproximadamente $70 \%$ da superficie. Apresenta o maior potencial produtivo da região e a maior biodiversidade e biomassa com espécies de grande valor econômico: madeireiro, oleaginoso, resinífero, aromatizante, corante, frutifero ou medicinal (AMAPAGE 2000).

Nas partes baixas que estão constantemente alagadas da planicie litorânea, encontra-se uma vegetação composta por manguezais, formando um ecossistema bem delimitado ao longo da região costeira e diretamente influenciado pela hidrodinâmica do Rio Amazonas. Esta região apresenta alta produtividade primária com significativa riqueza e diversidade de estoques faunísticos, estuários e oceânicos.

A castanheira e 0 angelim, árvores que podem atingir 40 metros de altura, são na região as espécies predominantes, e de grande importância econômica. O acapu, ucuúba, cedro, pau mulato, macacaúba, maçaranduba, jatobá, pracuúba, pau rosa, pau amarelo, piquiá, aquariquara, sucupira são comumente aproveitados pela indústria madeireira. Além dos vegetais 
acima, encontramos também grande quantidade de cipós, empregados na indústria de móveis artesanais, como as palmeiras, açaizeiro, bacabeiras, buritizeiro, tucumanzeiro, ubuçuzeiro e outras (GOVERNO DO ESTADO DO AMAPÁ 2001).

Uma das palmeiras mais importantes é o açaizeiro, cujo fruto é muito usado na alimentação. Com o caule constroem-se as habitações da população e com os caroços se faz o adubo empregado nas hortas. Nas matas, encontram-se plantas medicinais como a quina utilizada na terapêutica da malária.

A Floresta de Várzea compõe toda a área de influência fluvial e representa o ambiente típico da bacia amazônica, inclusive em termos de ocupação econômica formada pelas populações ribeirinhas. Aqui predominam espécies de alto valor produtivo e de grande importância sócioeconômica como o açaizeiro, andiroba, seringueira, virola, pau-mulato, macacaúba, entre outras (AMAPAGE 2000).

O cerrado ocupa a faixa de domínio geológico de formação de barreira que representa biogeograficamente um enclave do ambiente típico do Brasil Central. Apresenta um arsenal de espécies endêmicas e uma grande intervenção antrópica em razão da presença nesses ecossistemas dos principais cultivos florestais homogêneos.

O Campo de Várzea é um ambiente largamente distribuido no Estado, de natureza aluvial e submetido a regimes flúvio-pluviais ligados a um complexo sistema de drenagem que envolve cursos d'água, lagos temporários e permanentes.

A figura 3 apresenta em fotografia caracteristicas ecológicas da região estudada. 
Figura 3- Paisagem tipica da localidade de São Raimundo de Pirativa, Amapá, março, 2000.

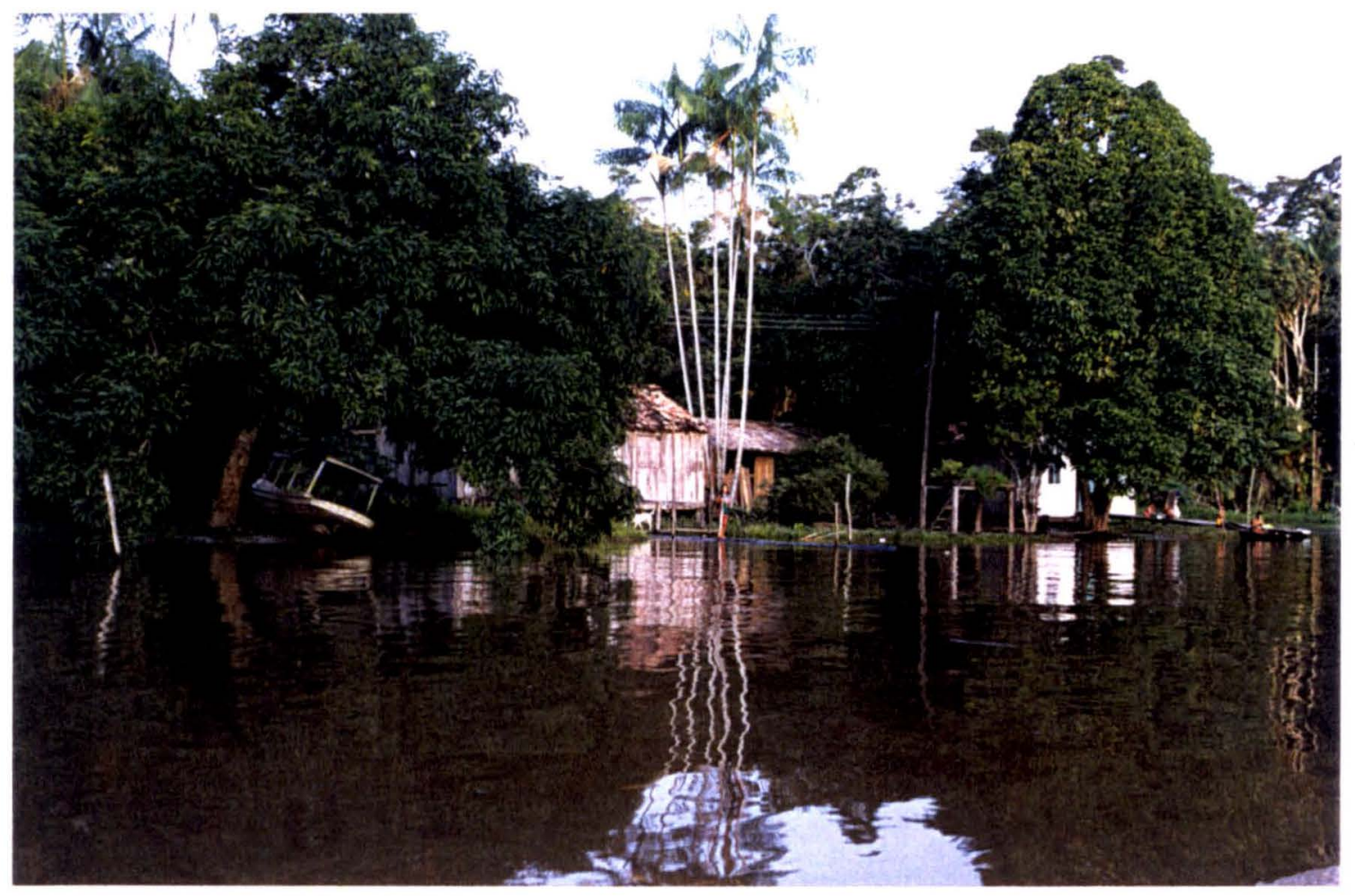

Fotógrafa: Sabrina dos Santos Ruiz 


\subsubsection{Fauna}

O Estado do Amapá apresenta grande diversidade faunística nativa, com algumas das espécies ameaçadas de extinção. Dentre as inúmeras espécies presentes destacam-se a onça pintada, araras, paca, macaco guariba, boto rosa, gavião real, papagaio, preguiça e peixe-boi, entre outras.

A onça pintada (Panthera onça), conhecida também por cangaçu, onça-canguçu, jaguaretê, jaguar, jaguar-canguçu, é encontrada com freqüência na região de São Raimundo de Pirativa. A cor é bastante variável, predominando o laranja e o preto, sendo a coloração das fêmeas mais clara que a do macho. Uma variação melânica da onça-pintada é a onça-preta, cuja pelagem amarela é substituída por uma outra mais escura, mantendo as rosetas. A onça se alimenta de peixes, veados, macacos, antas, tartarugas, jacarés, preguiças e pássaros (AMAPAGE 2000).

A espécie é hábil pescadora e nadadora, movendo-se de acordo com a presença das diversas espécies de presas que compõem sua dieta, especialmente nesta regiāo, onde as inundaçōes contribuem para a dispersão e deslocamento dos animais. Apesar do corpo compacto, ela se movimenta com graça e agilidade. Aproxima-se silenciosamente de sua vitima, atacando-a de improviso, geralmente fraturando--Ihe o pescoço. Depois arrasta a presa para o meio da vegetação, fazendo reserva de alimentos. Sua força é excepcional. O olfato não é aguçado, mas a visão é penetrante e acurada (AMAPAGE 2000)

A pele da onça é muito procurada pelos moradores da região, que caçam o animal para exportá-la ao Suriname ou à Guiana Francesa. Esta prática é o principal fator de diminuição da presença desta espécie na floresta. Os altos preços da pele no comércio exterior funcionarn como incentivo à contravenção. A bacia amazônica é uma das últimas regiōes brasileiras em que ainda são encontradas, porém o futuro da espécie pode ser comprometido em virtude da acelerada destruição de seu habitat. Nas localidades estudadas por nós, onde ocorre predomínio da pecuária de 
búfalos, as onças são caçadas pelos moradores por representarem risco permanente para o rebanho.

Outra espécie encontrada na região é o boto cor-de-rosa (Iniba geoffrensis), conhecido também como boto ou boto-vermelho. Alimenta-se de peixes, moluscos e crustáceos. A espécie é muito citada em lendas narradas pela população.

A anta (Tapirus terrestris) é um mamífero muito encontrado e apreciado como alimento na região. Chamada também de tapir, é um dos maiores animais terrestres presentes no Amapá. Mede até 2 metros de comprimento e 1 metro de altura, chegando a pesar $200 \mathrm{Kg}$. Mergulha e nada com facilidade, refugiando- se nas matas que beiram as águas dos rios, alimentando-se de frutas (AMAPAGE 2000).

Em relação às aves, estas ocupam um lugar de destaque no Estado do Amapá e vêm sendo estudadas no Programa de Prioridades de Conservação para a avifauna da Amazônia, no subprograma Aves do Amapá, 2001. Este programa contém um banco de dados com uma listagem de cerca de 400 espécies de aves do Estado.

O estudo das aves vem sendo realizado em diferentes ecossistemas do Amapá, entre eles, o ambiente do cerrado, incluindo-se áreas entre os eixos Macapá - Porto Grande - Amapá, em formações de cerradão, campo limpo, campo sujo e matas ciliares. Vem sendo feito também na Serra do Navio, nas localidades compreendidas entre Porto Grande (onde se Inicia o domínio da floresta amazônica), Serra do Navio e Serra Grande e em ambientes próximos ao litoral, abrangendo áreas de campos alagados e manguezais nas regiōes de Aporema, Pracuúba, nos arredores de Macapá e Santana (Vila Amazonas, Fazendinha, Lago dos Índios e Igarapé do Curiau) (PROGRAMA AVIFAUNA 2001).

Nas últimas áreas citadas, situam-se as localidades estudadas por nós próximas ao Rio Amazonas. Possuem florestas ribeirinhas que iuzem 
parte de uma região de transição, apresentando tanto aspecto florestal como de cerrado, de mata ciliar e de alagados.

De barco, pelos largos rios rodeados pelo verde da floresta, podemos apreciar o maravilhoso canto dos pássaros ou, com um pouco de sorte, observar duas das mais lindas aves encontradas na região: o guará (Eudocimus ruber) e a arara piranga (Ara macao) em seus ninhos. 


\subsubsection{Características socio-económicas}

\subsubsection{Infra-estrutura básica}

Esta região apresenta inúmeros problemas nos serviços de infraestrutura básica, saneamento, serviços de saúde, educação, abastecimento e transporte público.

O abastecimento é deficiente. Somente São Raimundo de Pirativa possui um pequeno estabelecimento comercial para venda de bebidas e poucos alimentos. Os moradores dirigem-se até Santana para compra de mercadorias. Não há infra-estrutura de saneamento básico nas localidades de São Raimundo de Pirativa, Santo Antônio e São João. A água usada para o abastecimento doméstico e para as atividades de trabalho é retirada diretamente do rio e estocada em galōes, bacias ou baldes de aluminio ou plástico, sendo assim utilizada pela população, sem tratamento prévio. Não existe tratamento de esgoto ou alguma forma mais sistematizada de coleta de lixo, o que expõe constantemente os moradores a diversas doenças, já que os rios recebem diretamente os dejetos provenientes da ocupação humana e dos chiqueiros, galinheiros e currais.

A presença de ratos é bastante comum no interior e nas circunvizinhanças das palafitas. Podemos observá-los a qualquer hora do dia na cozinha, armários, pias, fogões, guarda-roupas, dentro de sofás e caminhando pela casa. Os roedores domésticos são vistos de maneira natural pela população, que desconhece os malefícios que podem causar à saúde.

A figura 4 apresenta um exemplo da deficiência na infra-estrutura básica de saneamento encontrada nas três comunidades estudadas. 
Figura 4: Aspectos da infra-estrutura básica de saneamento presente na região do rio Matapi, Amapá, março, 2000.

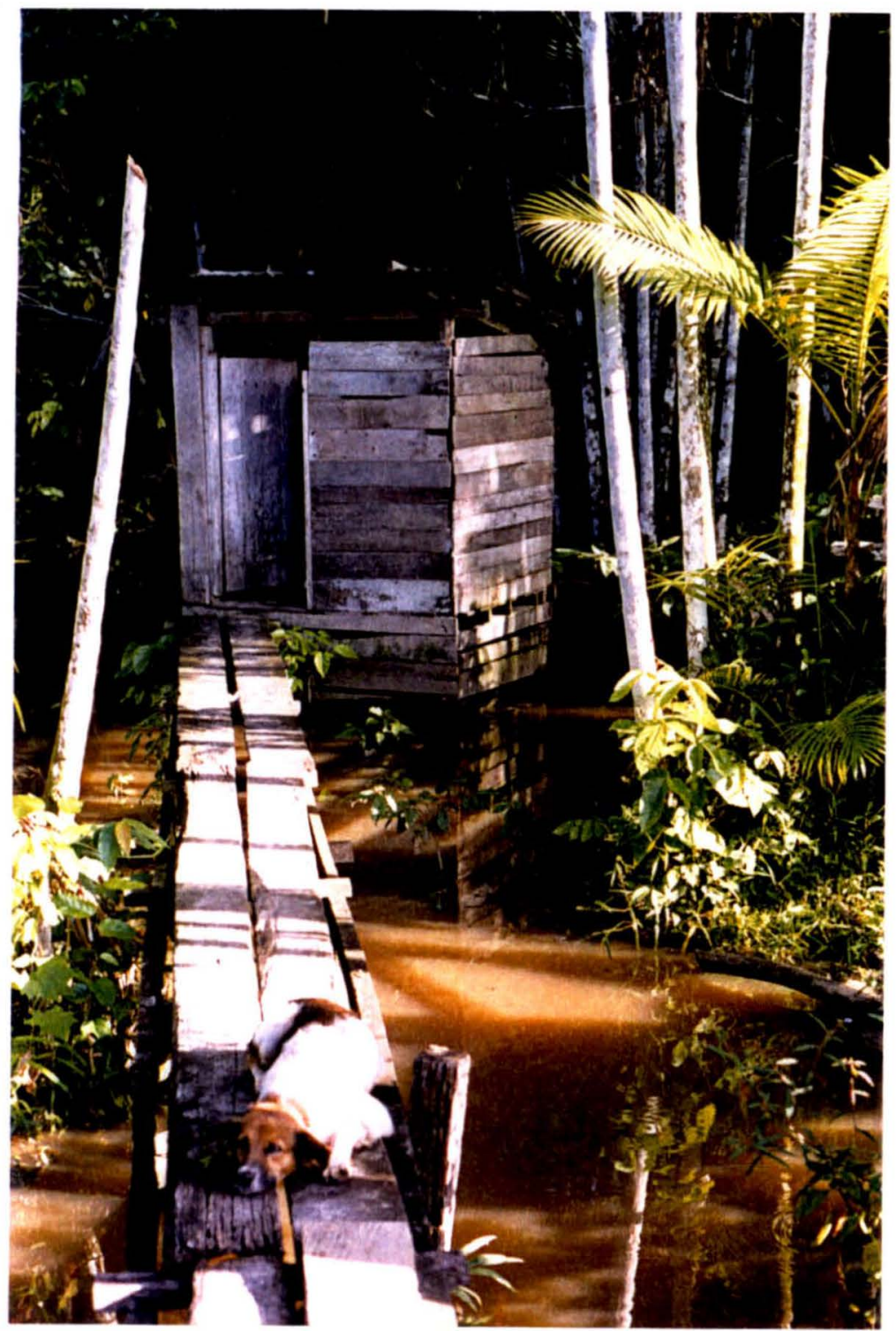

Fotógrafo: José Maria Soares Barata 


\subsubsection{Saúde}

O Estado do Amapá apresenta inúmeras dificuldades no atendimento à saúde da população, igualmente às demais regiões da Amazônia brasileira. Neste contexto, foi criado o Caixa Saúde, parte integrante do Programa de Desenvolvimento Sustentável do Amapá, visando a gestão descentralizada das ações de governo.

O Caixa-Saúde é uma experiência de descentralização da gestão governamental, na qual os recursos são repassados diretamente às unidades de saúde e administrados por uma associação formada por representantes da comunidade e servidores das unidades de saúde, na tentativa de tornar o atendimento mais ágil e eficiente (CAPIBARIBE 2001).

As parcerias de gerenciamento e responsabilidades propostas pela implementação do Caixa Saúde visam a facilitar e garantir a prestação de serviços e ações de saúde com melhor qualidade, além de serem mais próximas às realidades do usuário, uma vez que este participa com os gestores do sistema nos melhores caminhos para o melhor atendimento da população. O Caixa Saúde é uma sociedade civil, com responsabilidade juridica de Direito Privado, sem fins lucrativos e não integra a Administração Pública. Administra recursos transferidos pela Secretaria de Estado da Saúde e outros provimentos do Município, da Comunidade, de Entidades Públicas ou Privadas e da promoção de campanhas feitas pela Unidade de Saúde (GOVERNO DO AMAPÁ 2001).

Segundo dados do Ministério da Saúde, o Amapá apresentou, em 1996, para 10 mil habitantes, 6,25 médicos, 3,97 odontólogos 3,41 enfermeiros e dois leitos para cada 1 mil habitantes (IBGE 1997).

Nas localidades que estudamos não existem postos de atendımento médico e odontológicos para os moradores. Em razão das dificuldades do transporte, realizado unicamente de barco até Santana, se algum morador das comunidades ribeirinhas precisar de atendimento médico de emergência, correrá o risco de não chegar a tempo de receber socorro. 
emergência, correrá o risco de não chegar a tempo de receber socorro. Normalmente, o professor da região é solicitado pela população a levar com o barco da escola os moradores até o posto de atendimento mais próximo.

Outra questão enfrentada na região é a ação da FUNASA no atendimento aos casos de malária, cujas ações de controle são regionalizadas por município. Assim, as localidades de São Raimundo de Pirativa e de Santo Antônio pertencem ao municipio de Santana e a comunidade de São João, ao município de Mazagão. Embora muito próximas umas das outras, inúmeras vezes os moradores de uma das três comunidades não são atendidos pelos funcionários da FUNASA, durante a busca ativa, por residirem em municipios diferentes da área de ação da equipe, mesmo em casos de pacientes com sintomatologia de malária (depoimento obtido da Dona Maria, moradora de São Raimundo de Pirativa, líder comunitária da região). 


\subsubsection{Educação}

Segundo informações do Governo do Estado do Amapá, a educação é a principal prioridade do Estado, mais especificamente a educação fundamental (de $1^{\mathrm{a}}$ série até a $8^{\mathrm{a}}$ série), ensino médio ( 1 ano ao $3^{\circ}$ ano) e cursos profissionalizantes em particular, nas áreas carentes. $O$ ensino tem, como meta, a formação integral do aluno preservando e difundindo as culturas e línguas das diversas etnias (GOVERNO DO ESTADO DO AMAPÁ 2000).

O Estado mantém recursos para o ensino especial orientado para as instituiçōes filantrópicas e comunitárias, cujo objetivo é dar assistência a formação de pessoal especializado em ensino profissionalizante. Nas áreas rurais e costeiras, priorizam-se as técnicas de agricultura, pesca, exploração florestal e mineral.

A meta do Governo é a interiorização do ensino público, que vem sendo alcançada graças à fixação do professor nas comunidades mais afastadas, pelo fornecimento de moradia. A educação ambiental também é priorizada nesta região, sendo desenvolvida com parcerias entre o Governo Estadual e a UNICEF. Os projetos de ensino são adaptados à realidade das populações, desde a arquitetura de suas casas constituidas de madeira e palha até o plano pedagógico que prioriza o ensino de técnicas em manejo da fauna, flora e o ecoturismo. (CAPIBERIBE 2001).

Dados do IBGE de 1999 para o Estado mostram:

Criança de 7 a 14 anos fora da escola: $10,3 \%$,

Matrículas no ensino infantil: 8.974

Matrículas no ensino fundamental: 126.679

Matrículas no ensino médio: 28.599

Matriculas no ensino superior: 2.713

Analfabetismo: $12,98 \%$. 
As três localidades de nosso estudo possuem escolas de primeira a quarta séries, situadas ao longo do rio Matapi. Para dar continuidade aos estudos, as crianças devem ir ao municipio mais perto, Santana, o que favorece a desistência, visto que há carência de transporte na região. Alguns precisam remar mais de uma hora em pequenas canoas para chegar às salas de aula.

Os professores moram nas próprias comunidades onde lecionam. $O$ professor responsável pela escola em São João possui um barco que carrega as crianças de suas residências até a escola diariamente.

A figura 5 apresenta a fotografia do barco que transporta as crianças diariamente até a escola local. 
Figura 5: Meio de transporte utilizado pela Secretaria da Educação do Estado do Amapá na região do rio Matapi- Amapá, março 2000

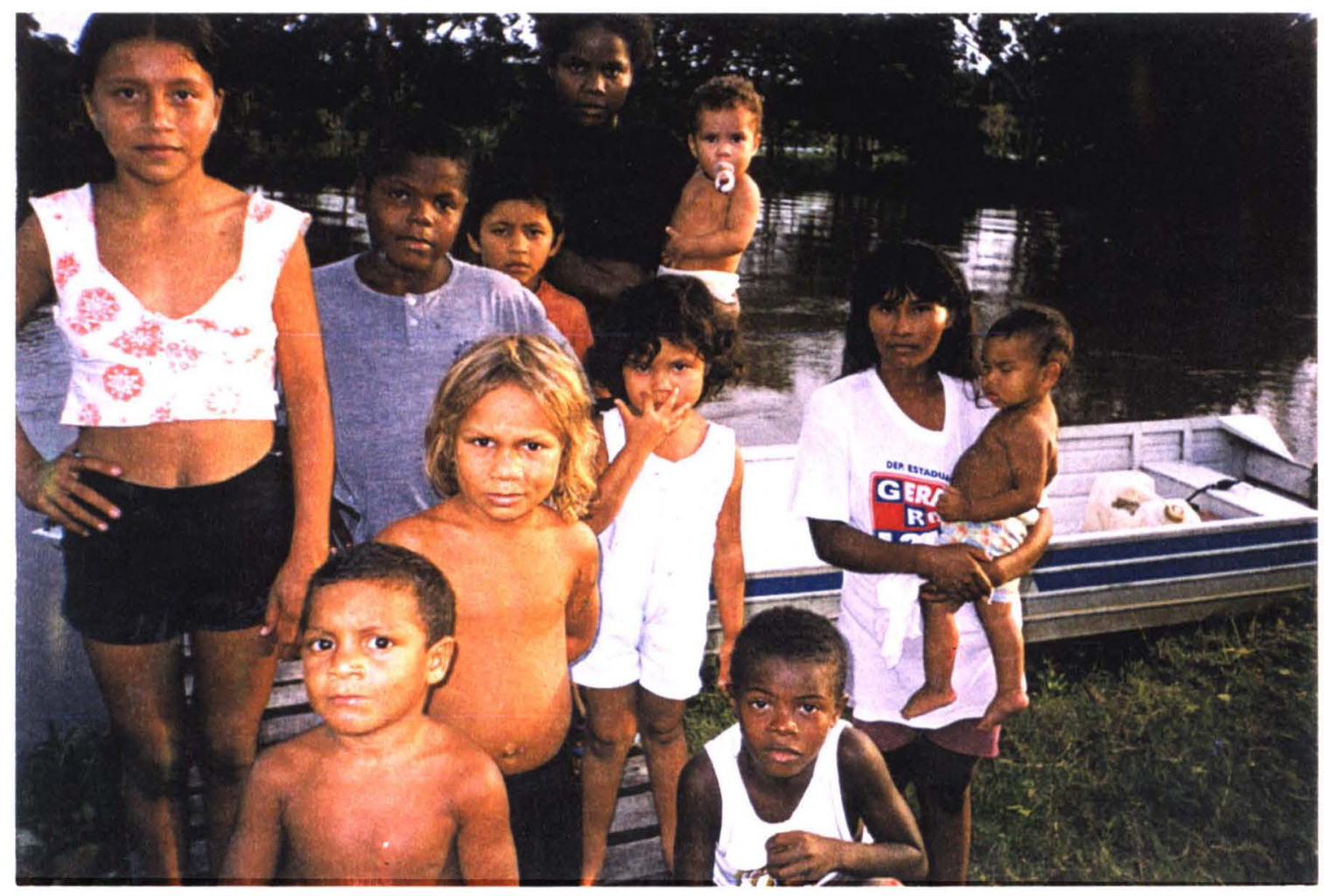

Fotógrafa: Sabrina dos Santos Ruiz 


\subsubsection{Economia}

A diversidade de ecossistemas caracterizada pela biogeografia da região somada à presença de recursos naturais propiciou uma taxa média anual de crescimento econômico de $4,4 \%$ entre 1990 e 1996 . O crescimento foi superior à média nacional de $3,1 \%$ e inferior ao crescimento populacional estadual de $5,3 \%$ ( SUDAM 1998).

O Amapá apresenta vantagens que podem ser bem aproveitadas no mercado econômico internacional, dado o fato de ser entrada para países da Europa e fazer fronteira com paises do Caribe apresentando um maior potencial de desenvolvimento quando comparado com outros estados da Região Amazônica.

A economia local depende diretamente dos recursos naturais, sendo assim exportadora de matérias-primas, de produtos primários e produtos semi-elaborados. O pino representa cerca de $50 \%$ da exportação total, seguido pelo palmito de açaí e o pescado.

A pesca é uma importante atividade extrativista no Estado. Com 698 $\mathrm{km}$ de costa banhada pelo Oceano Atlântico e área aproximada de $1200 \mathrm{~km}^{2}$ de rede hidrográfica, $O$ ambiente aquático apresenta grande importância para a população. Várias espécies de peixes e crustáceos de origem marinha e de água doce são capturadas pelos moradores da parte litorânea, na região da costa do Canal Norte do Rio Amazonas, que, pela combinação dos efeitos de correntes e marés, estende-se em sentido norte, ao longo do litoral, o que explica a presença da espécie da fauna de água doce nos ambientes costeiros do todo o litoral do Estado. As principais áreas produtoras de pescados são a costa oceânica, a desembocadura dos rios, a zona estuária e a planície flúvio-marinha, destacando-se a região dos lagos, interligada à reserva biológica do lago Piratuba (GOVERNO DO AMAPÁ 2001). 
Várias tentativas estão sendo desenvolvidas pelo Governo para desenvolver o setor pesqueiro, objetivando industrializar a produção e criando novos produtos como a polpa do pescado e subprodutos derivados com base nas partes descartadas na filetagem de peixes como gelatina, couro, farinha, pilulas de cartilagem de tubarão e ração.

Até o momento, a exploração dos recursos pesqueiros è artesanal. Somente a captura do camarão rosa (Pennaeus subtilis) é feita industrialmente, sendo a produção encaminhada aos centros urbanos para comercialização. As espécies mais capturadas são o dourado (Brachyplatystoma flavicans), o filhote (Brachyplatystoma $s p$ ), a gurijuba (Arius parken), a pescada amarela (Cynoscion aloupa), a pescada branca (Plagioscion surinamensis), e o caranguejo (Ucides cordatus) (AMAPAGE 2000).

O setor primário é extremamente reduzido no Estado, apresentando um baixo nível tecnológico. O extrativismo vegetal da castanha, borracha, açai e cacau encontra-se em pequena expansão.

O setor secundário também possui capacidade de expansão limitada em razão das deficiências de infra-estrutura causadas, sobretudo, pelo fornecimento de energia. Este setor é mantido pelo extrativismo mineral (exploração das jazidas de manganês, ouro, caulim e granito), pela construção civil e pela indústria de transformação, predominando a informalidade e o baixo nível tecnológico.

A principal riqueza mineral do Estado foi o manganês, com sua exploração iniciada em 1957. A mineração causou a formação das mais importantes reservas brasileiras e respondeu pela extração de mais de $80 \%$ da produção do Pais nesta atividade na década de 60 . O governo cedeu a jazida por licitação pública. O grupo vencedor obteve parceiros nos Estados Unidos para iniciar os trabalhos de prospecção, que duraram cerca de dois anos. A atividade contou com altos investimentos por parte do governo 
americano que, em razão de sua participação na Segunda Guerra Mundial, necessitava do metal para produzir armamentos (AMAPAGE 2001).

As jazidas foram arrendadas pelo período de 50 anos pela ICOMI, Indústria e Comércio de Mineração, do grupo Bethlehem Steel, pagando ao Governo royalties de $4 \%$ a $5 \%$ do valor do minério extraído. A renda dos royalties do manganês destinou-se à construção de uma usina, para assegurar base energética às futuras indústrias ali instaladas. Uma estrada de ferro foi construída com capacidade para 700 mil toneladas de manganês e 200 mil toneladas para outras mercadorias, e um porto, ao qual se viabilizou o acesso de navios com capacidade de 450 mil toneladas (AMAPAGE 2001).

Além do manganês, o ouro também é explorado nos garimpos dos rios Calçoene, Cassiporé, Gaivota e Igarapé de Leona, e os diamantes são encontrados na região de Santa Maria. A 80 km de Macapá, encontra-se uma jazida de 9,6 milhões de toneladas de hematita, com $70 \%$ de ferro, explorada pela empresa privada Hanna Company (AMAPABUSCA 2001).

Em relação ao setor terciário, que compreende a administração pública, encontramos o setor econômico mais representativo do Estado, cuja atividade de comércio e serviços superou a administração pública na geração de empregos nos últimos anos. Em 1995, entre os 102.445 individuos acima de onze anos de idade que desenvolviam alguma ocupação, $20 \%$ trabalhavam na administração pública, $21 \%$ na prestação de serviços e 19\% no comércio em geral (AMAPAGE 2001).

Houve ativação da economia local pelo estabelecimento da área livre de comércio de Macapá e Santana, com vantagens fiscais exclusivas para consumo e venda interna dos produtos nos setores de comércio, indústria de transformação, agropecuária, piscicultura, turismo e serviços. 
A atividade econômica da localidade de nosso estudo restringe-se à extração agrícola para a subsistência, pesca e criação de gado babuino e bovino.

\subsubsection{População e Migração}

O processo de urbanização no Estado do Amapá é acentuado, visto que $80,89 \%$ dos individuos vivem em áreas urbanas e $19,11 \%$ na zona rural. Entre 1991 e 1996, o Estado apresentou crescimento populacional de 5,3\% ao ano, passando de $\mathbf{2 8 9}$ mil para $\mathbf{4 3 0}$ mil pessoas. De acordo com o IBGE (1997), aproximadamente $50 \%$ deste crescimento decorre da migração proveniente do Pará, Maranhão e Ceará. A densidade populacional média é 2,3 habitantes por $\mathrm{km}^{2}$, uma das menores do Brasil. A maior concentração populacional encontra-se em Macapá e em Santana.

Os municípios mais populosos são Macapá (256.033 pessoas), Santana (81.949), Laranjal do Jari (27.671), Mazagão (12.989, Oiapoque (11.449), Porto Grande (8.384), Vitória do Jari (7.589), Amapá (6.298), Calçoene (6.014), Tartarugalzinho (4.543) (IBGE 2000). 
Figura 6: Moradia típica encontrada nas localidades de São Raimundo, Santo Antonio e São João, Amapá, março 2000.

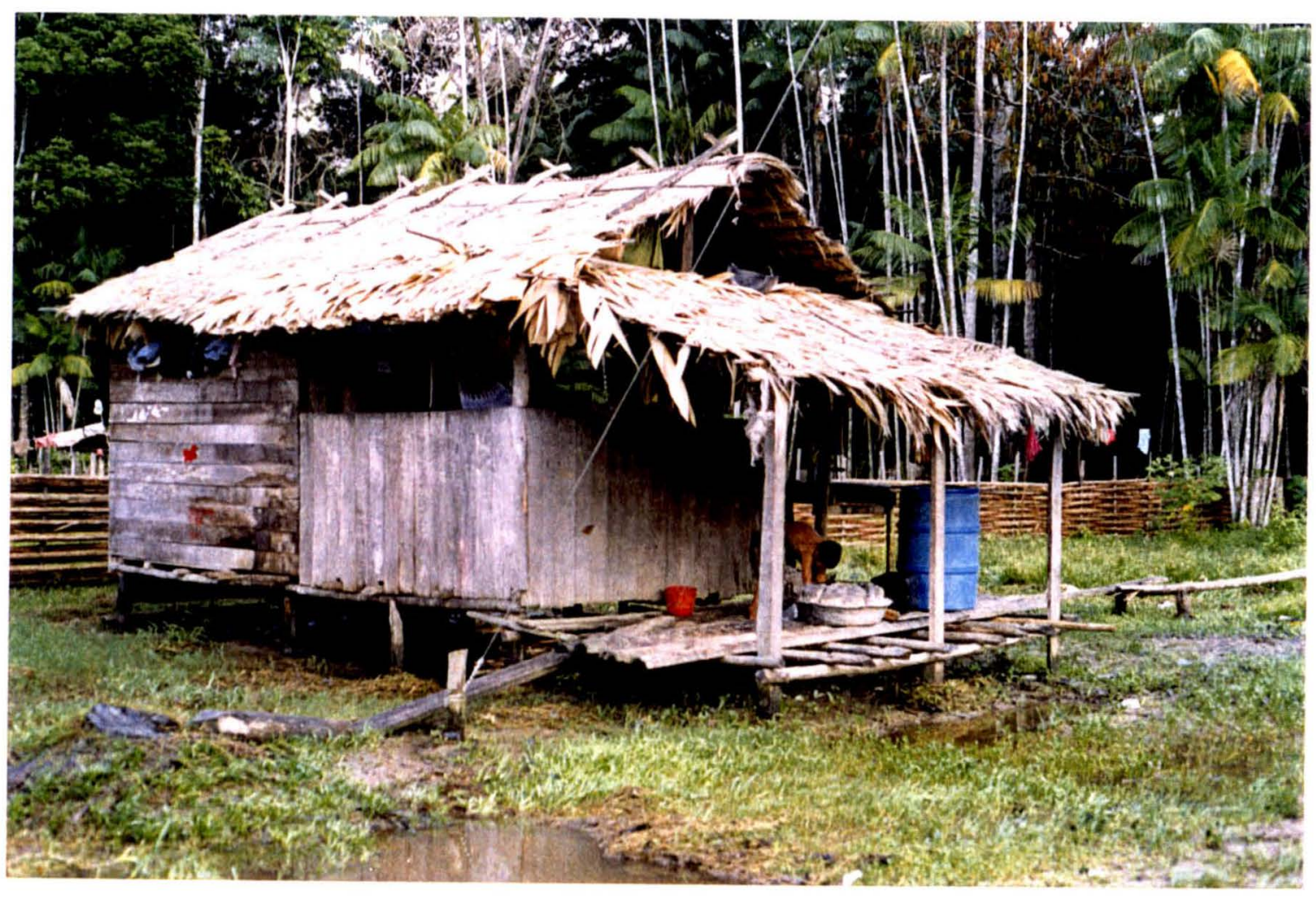

Fotógrafo: José Maria Soares Barata 
A formação étnica no Estado é diversificada (Figura 7), constituida por comunidades afro-americanas $e$ indigenas. $O$ Estado tem reservas indigenas protegidas que abrangem $40 \mathrm{mil} \mathrm{km}$, cerca de $30 \%$ de sua superficie total, o que equivale ao dobro da média da Região Norte do Brasil e quatro vezes mais que a média nacional.

As sociedades indigenas pertencem a seis etnias distribuidas nos municipios de Oiapoque, Amapari e Laranjal do Jari, totalizando 5.200 individuos. O Amapá foi o primeiro estado brasileiro a demarcar totalmente as áreas indígenas, formadas por duas reservas totalizando $140.276 \mathrm{~km}^{2}$ ( $8,6 \%$ do território estadual). Lá vivem as etnias Galibi, Karipuna, Karipuna, Palikur, Waiapi e Galibi Marworno (AMABUSCA 2001).

A luta das sociedades indígenas pela sobrevivência e garantia da preservação cultural e pela posse da terra recebe apoio de ONGs e dos governos alemão e francês. A viúva do ex-presidente francês François Miterrand, Danielle Miterrand, presidente da Fundação France Libertes, visitou o Amapá em abril de 1996, oferecendo apoio político às comunidades indígenas (MARTINS et. al 2000).

Os indios produzem artesanato para vender aos turistas, o que contribui como fonte de renda. Este artesanato apresenta padrões estéticos próprios, para cada sociedade, traduzidos nos objetos utilitários como os vasos, cestas, redes, armas e adornos produzidos com madeira, fibras, cerâmica, sementes, plumagem, dentes e ossos de animais, enfeitados com penas de aves ou pintados com corantes naturais extraídos de sementes de urucum ou casca de árvore.

A etnia africana está presente fortemente no Amapá desde o século XVIII, quando os primeiros escravos africanos foram trazidos. Atualmente a comunidade negra forma núcleos organizados, destacando-se a região do Curiaú, próxima de Macapá, formada por cinco comunidades (Curiaú de Dentro, Curiaú de Fora, Casa Grande, Curralinho e Mucambo) que totalizam cerca de 1.500 pessoas (AMAPABUSCA 2001). 
As comunidades conservam suas tradições culturais por meio de festas, danças, culinária e crenças religiosas. Em 1998, foram reconhecidas pela União como remanescentes de quilombo, o que lhes asseguram direitos constitucionais sobre o território que ocupam. Nas três localidades onde trabalhamos a maioria da população é de origem africana.

Figura 7: Moradores da região do Rio Matapi, Estado do Amapá, março 2000.
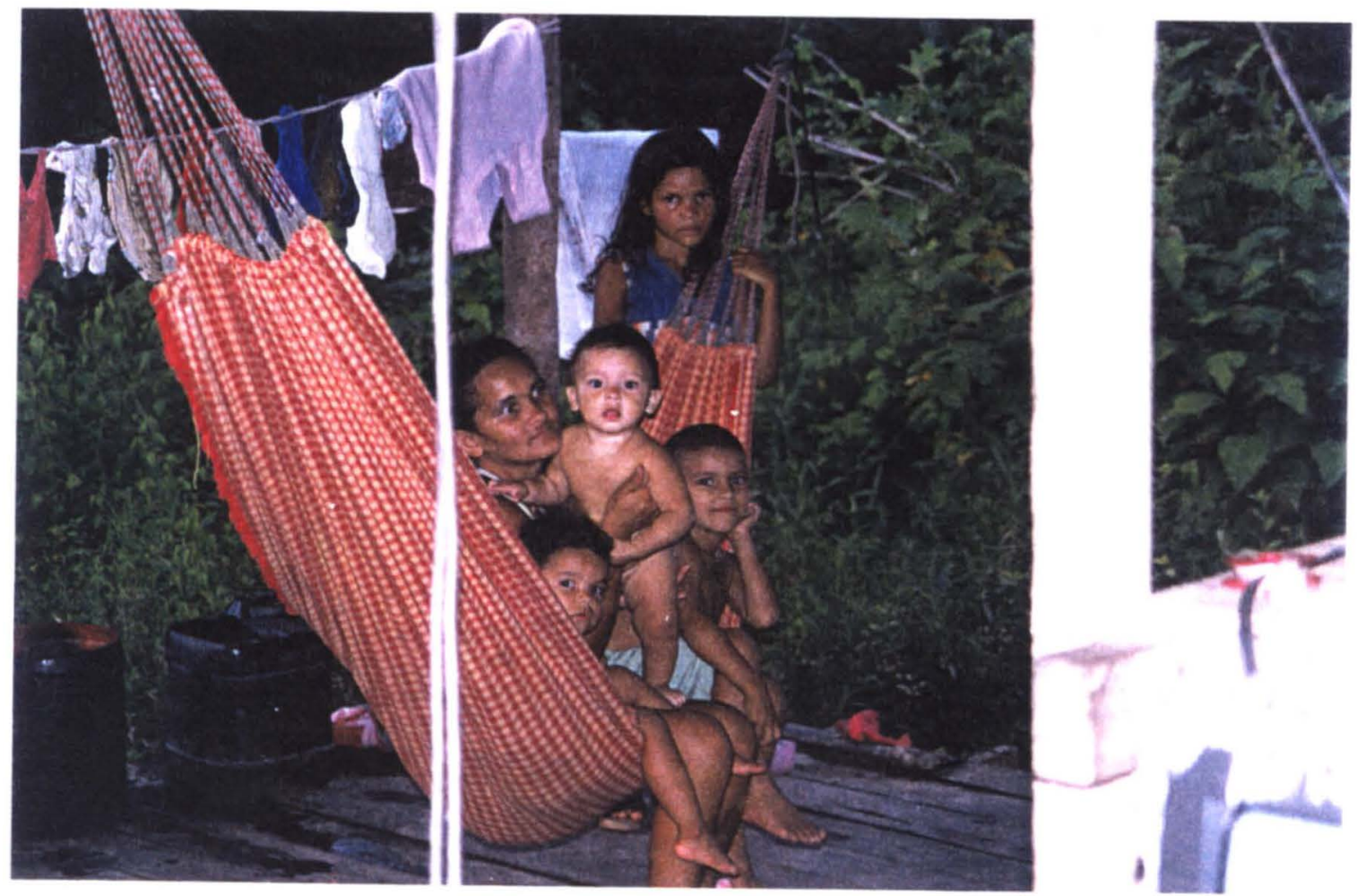

Fotógrafo: José Maria Soares Barata 


\subsubsection{Participaçōes das Organizaçōes não-Governamentais} (ONGs) e Associações.

O Estado do Amapá desenvolve vários trabalhos em parceria com Organizaçōes nāo-Governamentais e Associaçōes, sendo uma das principais metas do Governo nos últimos anos (CAPIBERIBE 2001).

Atualmente diversas entidades alemãs, francesas e holandesas desenvolvem juntamente com o Governo Estadual projetos de preservação e educação ambiental, além de projetos voltados para o desenvolvimento social e econômico atendendo a grupos organizados e não organizados, algumas delas bastante atuantes. Dentre os projetos mais relevantes do Amapá, destacam-se:

Projeto de Resgate da Memória e da Cultura Oral Indigena, Apalai. Governo do Estado em parceria com o Fundo das Nações Unidas para a Infåncia - UNICEF.

Projeto para Aquisição de Bolsa-parteira, para atender solicitaçāo do Projeto Resgate e Valorização das Parteiras Tradicionais do Amapá.

Projeto de Socializaçāo da Escola Bosque - Módulo Bailique, em convênio com o Centro Amapaense de Atividades Culturais, Econômicas e Sociais - CAACES.

Projeto Escola Familia Agricola do Pacui - Convênio com a Associação das Familias da Escola Agricola da Região do Pacui.

União dos Negros do Amapá

Projeto Programa de Apoio às Escolas de Palikur - Convênio com a Associação dos Povos Indigenas do Oiapoque - APIO.

Projeto Apoio ao Pescador Artesanal - convênio com a Federação dos Pescadores do Amapá - FEPAP. 
Projeto Tyhahsamo - Convênio com a Associação dos Povos Indigenas do Tumucumaque - APITU

Recuperação e Despoluição de Áreas de Terra Waiãpi degradadas do Garimpo - Convênio com o Centro de Trabalho Indigenista.

Subprojeto Lontra - Convênio com a Associação dos Agricultores da Comunidade do Lontra, do Distrito da Pedreira.

Beneficiamento da Produção Agroflorestal da Cooperativa Mista dos Produtores e Extrativistas do Rio Iratapuru - Convênio com a Cooperativa Mista dos Produtores e Extrativistas do Rio Itapuns COMARU.

Recuperação de Áreas Desmatadas de Florestas Nativas na Comunidade do km 142 - Efa com SAF - Convênio com o Sindicato dos Trabalhadores Rurais de Macapá - SINTRA.

Projeto de Desenvolvimento auto-sustentável da Cooperativa Mista Extrativista de Laranjal do Jari - Convênio com a Cooperativa Mista Extrativista Vegetal dos Agricultores do Laranjal do Jari.

Associação da Escola das Familias Agrícolas da Perimetral Norte BR 210, km 167, Cachorrinho Pedra Branca do Amapari.

Associação das Escolas-Familia da Região do Pacuí Rodovia Macapá-Cutias, km 123 Distrito de S. J. Pacui Macapá.

Associação dos Povos Indígenas do Oiapoque.

Associação dos Povos Indigenas do Tumucumaque - APITU

Associação dos Trab. Agro-extrativistas da Reserva do Rio Cajari.

Centro de Trabalho Indigenista/Programa Aaiãpi. 
Conselho Comunitário do Bailique

Conselho das Aldeias Waiãpi - APIN

Cooperativa Mista dos Prod. Extrativistas do R. Iratapuru COMARU

Escola Familia Agricola do Carvão

Distrito do Carvão - Queimada - Mazagão, AP

Federação dos Pescadores do Amapá - FEPAP

Instituto da Rede Brasileira Agroflorestal - REBRAF

Instituto de Estudos Sócios-Ambientais - IESA 


\subsection{ESTUDO DA POPULAÇÃO HUMANA}

\subsubsection{Coleta das informações epidemiológicas e do sangue venoso}

Foi aplicado um inquérito epidemiológico domiciliar contendo informaçōes sócio-econômicas e culturais que permitissem levantar os fatores de risco qualitativos na tentativa de caracterizar a malária local.

A coleta das informações epidemiológicas foi obtida diretamente dos participantes e, em caso de crianças menores, pelos pais ou responsáveis. As informações levantadas foram: idade, sexo, ocupação, grau de conhecimento da doença, sintomatologia, procedência, presença de malária anterior, utilização de medidas preventivas, espécie de plasmódio atual, assistência de serviços de saúde, atividades de lazer, atividades na mata, tempo de permanência na localidade e relato de deslocamentos.

O anexo 2 apresenta a ficha de investigação utilizada no inquérito epidemiológico. 


\subsubsection{Testes Parasitológicos}

\subsubsection{Descrição do teste da gota espessa e do esfregaço} sangüneo

A gota espessa, teste parasitológico de referência no diagnóstico da malária, foi preparada empregando-se metodologia preconizada pela OMS (BRUCE- CHWAAT 1985). O teste constitui-se na deposição de uma gota de sangue do paciente em lâmina de microscopia que, depois de sua secagem, é imersa em solução de azul de metileno fosfatado, a fim de promover a desglobinização e pré-coloração do material. Em seguida acrescenta-se à lâmina o corante de Giemsa, que após sete minutos é removido com água destilada. Após secagem do material a lâmina é examinada ao microscópio óptico com objetiva de imersão (100x) e ocular $(12,5 x)$ para a determinação da parasitemia.

Para P.falciparum a parasitemia foi quantificada pelo número de parasitas em relação ao número de leucócitos. Para cada gota de sangue contou-se 100 leucócitos, multiplicando-se o número resultante por 60 (considerando-se a média de leucócitos $6 \mathrm{mil} / \mathrm{mm} 3$ ) $\mathrm{O}$ valor obtido corresponde a aproximadamente a quantidade de parasitas/ $\mathrm{mm} 3$ (GREENWOOD e ARMSTRONG 1991).

Para P.vivax a parasitemia foi expressa em cruzes:

$++++=$ mais de 200 parasitas por campo

$+++=$ de 21 a 200 parasitas

$+++=$ de 2 a 20 parasitas

$++=1$ parasita por campo

$+/ 2=$ de 40 a 60 parasitas $/ 100$ campos 
O esfregaço sangüineo foi realizado com 1 a $2 \mu l$ de sangue extendido em lâmina de vidro. Depois da secagem o sangue foi fixado em álcool metílico e corado por 20 minutos em Giemsa a 5\%, previamente preparado em água tamponada destilada, pH 7,2. Após a coloração, a lâmina foi lavada, secada e examinada ao microscópio óptico comum com objetiva de imersão (100x) (WHO 1999). 


\subsubsection{Testes Imunológicos com os Soros humanos}

4.3.3.1. Padronização $\bullet$ Descrição da Reação do Imunofluorescéncia Indireta (IFI)

O teste foi executado protocolo de FERREIRA e SANCHEZ (1988), empregando-se antígeno de formas assexuadas de $P$. vivax e $P$. falciparum pesquisando-se anticorpos das classes $\operatorname{lgG}$ e $\operatorname{lgM}$. Não foram realizados testes com o antígeno de $P$. malariae pois nāo conseguimos as lâminas contendo o parasita, inicialmente obteriamos o material do Instituto Evandro Chagas em Belém a partir de macacos infectado experimentalmente, porém estes não apresentaram parasitemias satisfatória, impedindo assim, o processamento das amostras.

As lâminas com o antígeno foram preparadas no Laboratório de Malária da Superintendência de Controle de Endemias- SUCEN, São Paulo, com sangue de pacientes primo- infectados contendo prioritariamente as formas evolutivas de esquizontes e trofozoitas maduros do Plasmodium.

A suspensão de hemácias infectadas foi lavada em solução de PBS $\mathrm{pH} 7,2 \mathrm{e}$, em seguida, $10 \mu \mathrm{l}$ da solução foram adicionados em cada área demarcada da lâmina de vidro, usada no teste de fluorescência. Após secagem em temperatura ambiente e embrulhadas, as lâminas foram acondicionadas a $-70^{\circ} \mathrm{C}$. até serem processadas.

A determinação do limiar de reatividade da reação de IFI para a deteç̧ão de anticorpos anti formas assexuadas de P.falciparum e P.vivax das classes $\operatorname{lgM}$ e $\lg$ foi feita utilizando-se 30 soros negativos de área endêmica de malária. Os conjugados foram imunoglobulinas anti- $\operatorname{lgM}$ e anti IgG humanas (cadeias $\mu$ e $\gamma$ especificas) ligadas ao isotiocianato de fluoresceina. Inicialmente foi feita uma titulação em bloco empregando-se diluições crescentes do conjugado contra diluições crescentes dos soros, para verificação da diluição ideal do conjugado fluoresceina. 
Foram testados soros controles positivos e negativos em três diluições de conjugado, 1:500, 1:1000 e 1:2000 para se obter resultados que melhor discriminassem a positividade. O limiar de reatividade foi expresso pela reciproca da diluição, 20 para $\operatorname{lgM}$ e 40 para IgG, com os conjugados diluídos à 1/1000, uma vez que os soros negativos apresentaram valores sempre abaixo desse titulo.

Tabela 6. Padronizaçăo do toste de Imunofluorescéncia Indireta (IFI) com formas assexuadas de P.vivax e P.falciparum para detecção de anticorpos da classe IgG. Conjugado anti-lgG humano. Resultados expressos em cruzes, relativas à intensidade da fluorescência (Positivos a partir de 1+).

\begin{tabular}{|c|c|c|c|c|c|c|}
\hline Ant-IgG & \multicolumn{2}{|c|}{$1: 500$} & \multicolumn{2}{|c|}{$1: 1000$} & \multicolumn{2}{|c|}{$1: 2000$} \\
\hline Soros & $1: 20$ & $1: 40$ & $1: 20$ & $1: 40$ & $1: 20$ & $1: 40$ \\
\hline P. vivax & $3+$ & $3+$ & $2+$ & $2+$ & $1 / 2+$ & $1 / 2+$ \\
\hline P.fakiparum & $3+$ & $3+$ & $3+$ & $2+$ & $1+$ & $1+$ \\
\hline Negativo - & $1 / 2+$ & $(-)$ & $(-)$ & $(-)$ & $(-)$ & $(-)$ \\
\hline
\end{tabular}

"Soro positivo Pv (lgG): Soro de área endémica - Soro positivo Pf (lgG): Soro de área endémica.

- Soro negativo de área endémica

Limiar de reatividade: $1: 40$ (com 30 soros negativos testados com conjugado 1:1000.

Tabela 7. Padronização do teste de Imunofluorescência Indireta (IFI) com formas assexuadas de P.vivax e P.falciparum para deteç̧ão de anticorpos da classe IgM. Conjugado anti-lgM humano. Resultados expressos em cruzes, relativas à intensidade da fluorescéncia (Positivos a partir de 1+).

\begin{tabular}{|c|c|c|c|c|c|c|}
\hline AntilgM & \multicolumn{2}{|c|}{$1: 500$} & \multicolumn{2}{|c|}{$1: 1000$} & \multicolumn{2}{|c|}{$1: 2000$} \\
\hline Soros & $1: 20$ & $1: 40$ & $1: 20$ & $1: 40$ & $1: 20$ & $1: 40$ \\
\hline P. vivax & $3+$ & $3+$ & $2+$ & $1+$ & $1 / 2+$ & $1 / 2+$ \\
\hline P. falciparum & $3+$ & $3+$ & $3+$ & $2+$ & $1+$ & $1+$ \\
\hline Negativo - & $(-)$ & $(-)$ & $(-)$ & $(-)$ & $(-)$ & $(-)$ \\
\hline
\end{tabular}

"Soro positivo Pv (IgM): Soro de área endêmica - Soro positivo Pf (IgM): Soro de área endêmica.

- Soro negativo de área ondémica

Limiar de reatividade: 1:20(com 30 soros negativos testados com conjugado 1:1000. 


\section{Descrição da técnica}

Inicialmente foram acrescentos às lâminas contendo o antígeno, $10 \mu$ | de cada soro que foi previamente diluído em PBS- Tween 80 a 1\%, a razão 2 , a partir de 1/20 e 1/40 respectivamente para a pesquisa de anticorpos antiformas sangüineas da classe IgM e IgG. As lâminas foram incubadas por 30 minutos a $37^{\circ} \mathrm{C}$ em câmara úmida, lavadas duas vezes em PBS (1C minutos cada) e secas. Posteriormente, o conjugado marcado com fluoresceina previamente titulado e diluído em solução de azul de Evans, foi acrescentado às lâminas, incubando as mesmas em câmara úmida por 30 minutos a $37^{\circ} \mathrm{C}$. Para a remoção do excesso de conjugado as lâminas foram lavadas duas vezes em PBS, secas e montadas com glicerina pH 9,5.

\subsubsection{Padronização e descrição do ELISA com os soros humanos}

O ELISA foi executado baseado na metodologia de ZAVALA et. al (1986), modificada por CURADO et. al (1997) e DUARTE (1998) para a detecção de anticorpos da classe IgG, com peptídeos sintéticos correspondentes à porção repetitiva especifica para a proteina circunsporozoita (CS) de:

P. brasilianum/P. malariae : MAP-29 (multiple antigen peptide): $\left[\left(\mathrm{NAAG}_{4}\right]_{4}\right.$ (LAL et. al 1988).

P. vivax clássico: Polímero de 45 aminoácidos (DDAAD) $)_{9}$ contendo 5 aminoácidos repetitivos (NARDIN et. al 1982).

P. vivax VK247:- Peptídeo com 36 aminoácidos (ANGAGNQPG) 4 contendo 9 aminoácidos repetitivos (ROSENBERG et. al 1989).

$P$. vivax-like humano/P. simiovale PL-35, com 33 aminoácidos contendo 11 aminoácidos repetitivos (APGANQEGGAA) 3 (QARI et. al 1993).

P.falciparum: (NANPNVDP) 3 (NANP) 9 (NARDIN et. al 1982). 
Estes peptídeos inicialmente seriam produzidos pelo Dr. Antônio de Miranda do Departamento de Biofisica da Escola Paulista de Medicina, entretanto após inúmeras tentativas de sintese, não se conseguiu resultados satisfatórios, desta forma para $P$. vivax e $P$.falciparum utilizamos peptideos fornecidos pela Dra. Ruth Nussensweig, da Universidade de Nova York e para as demais espécies os peptídeos foram doados pelo Dr. Almério de Castro Gomes do Departamento de Epidemiologia da Faculdade de Saúde Pública da Universidade de São Paulo. Para padronização do ELISA foram feitas titulações em bloco para definição das concentrações ótimas de cada um dos peptídeos sintéticos, frente à diferentes diluições de soros positivos e negativos.

Em uma triagem inicial foram selecionados 30 soros provenientes do Banco de Sangue do Hospital das Clínicas da Faculdade de Medicina da Universidade de São Paulo, sem história epidemiológica ou clínica de malária. Uma vez definidas as concentrações ideais dos peptideos, as diluiçōes dos soros e do conjugado, 30 amostras de soros negativos provenientes das coletas realizadas no Amapá foram processadas escolhidas aleatoriamente, para o estabelecimento do limiar de reatividade do método.

$$
\text { C. } O=X+3 S D
$$

onde: $X$ é a média aritmética das absorbâncias dos soros padrão negativo e SD é o desvio- padrão obtido.

A padronização do ELISA foi feita para cada um dos peptídeos sintéticos separadamente, para isto, foram selecionados soros positivos e negativos por de critérios clínicos, sorológicos e epidemiológicos.

Inicialmente foram executadas titulações em bloco para definição das concentrações ótimas de cada peptídeo sintético, frente às diferentes diluições de soros positivos e negativos. Nesta titulação, ficou estabelecido 
que as concentrações ideais para todos os peptideos era de $10 \mu \mathrm{l} / \mathrm{ml}$, nas diluiçōes dos soros a 1:50 e diluição do conjugado anti lgG humano peroxidase à concentração de 1:250. Nas concentrações acima observou-se absorbâncias máximas com os soros com IFI positiva e mínima com os soros negativos, seja de Banco de Sangue de São Paulo ou do Amapá.

Foram realizados alguns testes para a escolha do tipo de placa de microtitulação que oferecesse melhores resultados e fossem de fácil obtenção. Foram ensaiadas placas NUNC (Maxisorp e Polisorp) onde optou-se pelas de poliestireno tipo Maxisorp, visto que, não foram observadas dificuldades na aderência dos peptideos ou "efeito borda", assim como, nenhum outro problema de ordem técnica.

Para a determinação do limiar de reatividade das reaçōes foram executadas triagens iniciais, onde selecionaram-se 30 soros provenientes do Banco de Sangue do Hospital das Clinicas da Faculdade de Medicina da Universidade de Sāo Paulo, sem história epidemiológica ou clinica de malária.

Após serem definidas as concentraçōes ideais dos peptideos, as diluições dos soros e do conjugado, foram processadas 30 amostras de soros negativos provenientes das coletas realizadas no Amapá, escolhidos aleatoriamente, estabelecendo-se assim, um limiar de reatividade mais fidedigno.

Nas tabelas 8 e 9 foram demonstrados os valores do limiar de reatividade para P.falciparum, P.vivax, P.malariae, P.vivax VK247 e $P$.vivax like, pelo emprego de 30 amostras de soros provenientes do Banco de Sangue de São Paulo e 30 soros de área endêmica de malária. 
Tabela 8: Valores do limiar de reatividado para cinco peptideos sintéticos, pelo emprego de 30 amostras de soros provenientes do Banco de Sangue de São Paulo.

Tabela 8

\begin{tabular}{c|c|c|c|c|c}
\hline Peptideos & P. falciparum & P. vivax & P.malariae & $\begin{array}{l}\text { P.vivax } \\
\text { VK247 }\end{array}$ & $\begin{array}{c}\text { P.vivax } \\
\text { like }\end{array}$ \\
\hline Média & 0.041 & 0.039 & 0.049 & 0.059 & 0.091 \\
\hline DP & 0.022 & 0.023 & 0.019 & 0.020 & 0.032 \\
\hline M+2DP & 0.085 & 0.085 & 0.087 & 0.099 & 0.155 \\
\hline M+3DP & 0.107 & 0.108 & 0.106 & 0.119 & 0.187 \\
\hline
\end{tabular}

M= Módia das absorbáncias

DP= Desvio Padrão

Tabela 9: Valores do limiar de reatividado para os cinco peptideos sintéticos, pelo emprego de 30 amostras de soros provenientes de área endémica de malária, colotados no estado do Amapá.

Tabola 9

\begin{tabular}{c|c|c|c|c|c}
\hline Peptideos & P. falciparum & P. vivax & P.malariae & $\begin{array}{c}\text { P.vivax } \\
\text { VK247 }\end{array}$ & $\begin{array}{c}\text { P.vivax } \\
\text { like }\end{array}$ \\
\hline Média & 0.075 & 0.067 & 0.067 & 0.071 & 0.119 \\
\hline Desvio & 0.021 & 0.022 & 0.022 & 0.027 & 0.040 \\
\hline m+2DP & 0.117 & 0.111 & 0.111 & 0.125 & 0.199 \\
\hline m+3DP & 0.138 & 0.133 & 0.133 & 0.152 & 0.239 \\
\hline
\end{tabular}

$M=$ Média das absorbáncias

DP= Desvio Padrão

Descrição da técnica 
Para executar o ELISA foram usadas placas de microtitulação de poliestireno da marca NUNC, que foram sensibilizadas por 15 horas a $4^{\circ} \mathrm{C}$ com $100 \mu$ l de peptídeo sintético em PBS pH 7,2, cuja concentração ideal foi previamente determinada. Após cinco lavagens com solução de PBS pH 7,2 contendo $0,05 \%$ de Tween 20 (PBS-T), as placas foram bloqueadas com $200 \mu$ l de PBS-T20, leite molico desnatado a $5 \%$, permanecendo por um período de duas horas à $37^{\circ} \mathrm{C}$, em câmara úmida.

Após novo ciclo de lavagens com PBS-T, foram adicionados $100 \mu \mathrm{l}$, dos soros nas diluições de 1/50,1/100 e 1/200 em solução de leite a 1\%, acrescidos dos controles positivos e negativos dos testes, com nova incubação a $37^{\circ} \mathrm{C}$ por uma hora em câmara úmida. Em seguida, as placas foram submetidas a um novo ciclo de lavagens.

Posteriormente, $100 \mu$ do conjugado peroxidase IgG humano, diluido em solução de leite a 1\% em PBS foram adicionados à placa mantida por 30 minutos de incubação à $37^{\circ} \mathrm{C}$ em câmara úmida. As placas foram lavadas cinco vezes em solução de PBS-T e uma vez em água destilada, adicionando-se a seguir $100 \mu \mathrm{l}$ da mistura cromógena ABTS. Após 30 minutos, à temperatura ambiente, a reação enzimática foi interrompida pela adição de $50 \mu$ de SDS a $20 \%$ em água destilada. Os valores de absorbância são obtidos, após leitura das reaçōes a $414 \mathrm{~nm}$ em leitor de ELISA (MULTISKAN MCC/340P). Os volumes acima referidos correspondem ao volume em cada cavidade da placa de ELISA. Todos os testes foram feitos em duplicata.

Para os testes de especificidade, foram usados peptideos não relacionados. 


\subsection{Estudo Entomológico}

\subsubsection{Obtenção, identificação $\theta$ acondicionamento dos anofelinos}

Os anofelinos foram obtidos por de capturas entomológicas de 12 horas, em ambiente intradomiciliar e peridomiciliar, empregando-se a técnica de isca humana, visando a obtenção de dados para caracterização dos vetores possivelmente envolvidos na transmissão da malária local. Tais mosquitos foram capturados pela equipe de campo coordenada pelo $\mathrm{Dr}$. Jaco Voorhan (pesquisador do Instituto Estadual de Pesquisa do AmapáIEPA), que realiza o trabalho em colaboração com a autora deste estudo.

Nas capturas entomológicas foram preenchidas fichas contendo as seguintes informaçōes: características do habitat, tipo de armadilha empregada, horário das coletas, número de exemplares obtidos, proximidade dos sítios de captura com residências, coleções hidricas ou mata.

Os anofelinos foram mortos com clorofórmio e em seguida acondicionados em tubos de vidro tipo hemólise contendo sílica gel, mantidos à temperatura ambiente até serem identificados e processados para a pesquisa de $P$.vivax, $P$.vivax VK 247, $P$.vivax-like humano, $P$.malariae e P.falciparum.

A identificação do subgênero Nyssohynchus foi realizada utilizando-se a chave taxonômica, segundo FARAN e LINTHICUM (1981). A chave de ROTRAUT e OLIVEIRA (1994) foi utilizada para os demais subgêneros. 


\subsubsection{Detecção da infecção malárica nos anofelinos}

Para a pesquisa de infecção malárica nos anofelinos utilizou-se o ELISA. Foi necessário um estudo prévio obrigatório do teste, incluindo-se a produção de anticorpos monoclonais e padronização da técnica com os antígenos.

\subsubsection{Padronização $\theta$ Descrição do ELISA com os Anofelinos}

\subsubsection{Anticorpos monoclonais}

O ELISA foi realizado empregado-se anticorpos monoclonais dirigidos contra as regiōes repetitivas especificas do antígeno circunsporozoita (CS) do P.falciparum (2A10) e P.vivax (2F2) (NARDIN et. al 1982), P.vivax VK247 (2E10) (ROSENBERG et. al 1989), P.vivax like/ P.simiovale (QARI et. al 1993 e P.malariae (6B10). (COCHRANE et. al 1992).

Estes anticorpos monoclonais foram produzidos seguindo protocolo de VENKATACHALAM et. al 1994 no Laboratório de Protozoologia do Instituto de Medicina Tropical de São Paulo, partindo de hibridomas que foram doados pela Dra. Ruth Nussenzweig da Universidade de Nova York.

4.4.3.2. Antigenos utilizados como padrão positivo e negativo e obtenção dos esporozoitas

Como padrōes positivos do ELISA foram utilizados peptideos sintéticos, proteinas recombinantes ou esporozoítas de plasmódios: 
Para a deteç̧ão do $P$. vivax VK 247, empregou-se esporozoitas obtidos de $A n$. stephensi e An. dirus infectados por intermédio da alimentação em chimpanzés esplenectomizados e inoculados previamente com cepa isolada de paciente proveniente da Tailândia (ROSENBERG et. al 1989), ou o peptídeo sintético (ANGAGNQPG) 4 (COCHRANE et. al 1990).

Os exemplares de An.stephensi e An.dirus infectados com P.vivax VK247 foram fornecidos pelo Dr. W.E.Collins do Centers for Diseases Control, Atlanta.

Para a detecção do $P$. vivax e $P$. falciparum utilizamos proteinas CS recombinantes produzidas partindo da transformação plasmidica da levedura Saccharomyces cerevisiae, cepa 2168, na qual foi inserida parte dos genes que codificam as proteínas $\mathrm{CS}$, que no caso do $P$. vivax corresponde aos resíduos de aminoácidos 77 a 335 , contendo a região repetitiva (DDAAD)9 (BARR et. al 1987) e no $P$. falciparum aos aminoácidos 43 a 348 contendo toda a região repetitiva (NANP) ${ }_{3}$ (NARDIN et. al 1982). Na detecção do $P$. malariae/ $P$. brasilianum, utilizamos o peptídeo sintético $\left[(\mathrm{NAAG})_{4}\right]_{4}$ (COCHRANE et. al 1992 e para P.vivax like/ P.simiovale o peptideo sintético (APGANQEGGAA) 3 com 33 aminoácidos contendo 11 aminoácidos repetitivos (QARI et. al 1993).

Nos testes de especificidade foram empregados além dos antigenos padrões positivos descritos acima, esporozoitas de $P$. berghei e $P$. cynomolgi obtidos de An. stephensi infectados experimentalmente na Universidade de Nova York.

\section{Padrões negativos}

Como controle negativo foram usados An. stephensi e An. friborni criados em insetário, mantidos em sala climatizada sob a temperatura de $26^{\circ} \mathrm{C} \pm 1^{\circ} \mathrm{C}$ e umidade relativa do ar de $80 \% \pm 5 \%$. Os anofelinos foram fornecidos pela Dra. Ruth Nussenzweig da Universidade de Nova York. 


\section{Obtenção dos esporozoitas}

Os esporozoitas foram obtidos pela metodologia descrita por OZAKI et. al (1984). O tórax e a cabeça de cada anofelino infectado em laboratório foram colocados em um tubo de plástico (tipo Eppendorf) de $0.5 \mathrm{ml}$ com o fundo furado com agulha e contendo lã de vidro, onde se adicionou $200 \mu \mathrm{l}$ de meio de cultura RPMI. O tubo foi colocado dentro de outro tubo Eppendorf de 1,5 ml, e em seguida centrifugado por 3 minutos a $1.500 \mathrm{rpm}$ a uma temperatura de $5^{\circ} \mathrm{C}$. O sobrenadante foi desprezado, e após os esporozoitas serem ressuspendidos em meio RPMI, foram contados em câmara de Neubauer, calculando-se a concentração para cada espécie estudada. O procedimento descrito acima foi realizado em banho de gelo

\subsubsection{Conjugação do anticorpo monoclonal a biotina.}

A conjugação dos AcMos à biotina foi efetuada com AcMo na concentração de $1,0 \mathrm{mg} / \mathrm{ml}$ diluida em PBS pH 7,2, acrescentando-se a cada $100 \mu \mathrm{l}, 10 \mu \mathrm{l}$ de solução de biotina previamente preparada em DMSO na concentração de $1,0 \mathrm{mg} / \mathrm{ml}$.

Após incubação por 4 horas à temperatura ambiente, foram adicionados $11 \mu$ de cloreto de amônio $1 \mathrm{M}$ (diluido em PBS/BSA 1\%), sob agitação. A solução foi dialisada duas vezes (24 horas cada) contra PBS pH 7,2 .

Depois da biotinilação de cada lote de AcMo, o teste para a verificação da concentração ótima de uso foi utilizado, titulando-se seriadamente o anticorpo monoclonal biotinilado. Placas de microtitulação foram sensibilizadas com o AcMo; após o bloqueio foram adicionados os antígenos controles positivos e negativos, em seguida, foram acrescentadas as diluições seriadas do AcMo biotinilado. Após a adição da peroxidase e do 
substrato, a reação foi interrompida e em seguida foi realizada a leitura do nivel de absorbância a $414 \mathrm{~nm}$.

Esta padronização foi repetida para cada lote de AcMo biotinilado produzido ao longo dos experimentos.

\subsubsection{Determinação das concentrações ideais dos anticorpos} monoclonais $\theta$ do conjugado imunoenzimático

Os AcMos utilizados na captura do antigeno e o conjugado estreptoavidina- peroxidase foram titulados simultaneamente, determinandose as concentrações ótimas dos anticorpos e o título do conjugado imunoenzimático. Nesta padronização, foram usadas partidas de AcMo conjugadas com biotina, anteriormente, testadas em outro sistema.

As titulações foram efetuadas em bloco, testando-se paralelamente as concentrações de $0,125 \mathrm{mg} / \mathrm{ml}, 0,25 \mathrm{mg} / \mathrm{ml}, 0,5 \mathrm{mg} / \mathrm{ml}, 1,0 \mathrm{mg} / \mathrm{ml}, 2,5 \mathrm{mg} / \mathrm{ml}$, $5,0 \mathrm{mg} / \mathrm{ml}, 7,5 \mathrm{mg} / \mathrm{ml}$ e $10,0 \mathrm{mg} / \mathrm{ml}$ para os quatro anticorpos, frente às diluiçōes do conjugado de 1/6000, 1/8000.1/10000 e 1/12000, contra as concentrações dos controles positivos (peptídeos sintéticos e proteinas recombinantes) a $0,25 \mathrm{mg} / \mathrm{ml}, 0,5 \mathrm{mg} / \mathrm{ml}, 1,0 \mathrm{mg} / \mathrm{ml}$ e $2,0 \mathrm{mg} / \mathrm{ml}$ e $12,25,50$, 100,200 e 400 (número de esporozoitas) e mosquitos negativos triturados, suspensos em PBS-T20, 1\% BSA, na proporção de 1 ou 0,5 anofelino por $200 \mu$ l. As reações foram realizadas em duplicata. 


\subsubsection{Determinação das concentraçõos ideais de antigenos} (proteínas recombinantes o poptídeos sintéticos)

As concentraçōes ideais dos controles positivos empregados no ELISA foram avaliadas, diluindo-se seriadamente os antigenos nas placas de microtitulação.

Os ensaios foram realizados sensibilizando-se as placas com o AcMo na concentração ideal para cada espécie de plasmódio e após as lavagens e o bloqueio com PBS-T20,5\% BSA, acrescentaram-se as concentrações de $0,078 \mathrm{mg} / \mathrm{ml}, 0,156 \mathrm{mg} / \mathrm{ml}, 0,312 \mathrm{mg} / \mathrm{ml}, 0,625 \mathrm{mg} / \mathrm{ml}, 1,25 \mathrm{mg} / \mathrm{ml}, 5,0 \mathrm{mg} / \mathrm{ml}$ e $10,0 \mathrm{mg} / \mathrm{ml}$ das proteinas recombinantes e dos peptídeos sintéticos, além dos padrões negativos. Em seguida, acrescentaram-se o AcMo biotinilado, peroxidase e substrato. As reações foram feitas simultaneamente e em duplicata.

\subsubsection{Testes de especificidade}

A especificidade foi verificada pela sensibilização das placas com 50 $\mu \mathrm{l}$ de anticorpo monoclonal (P.falciparum, P.vivax, P.vivax variante VK247, P.malariae e P.vivax like/simiovale), na concentração ideal para cada espécie estudada e após o bloqueio com $150 \mu$ l de PBS-T20 BSA $5 \%$, foram adicionados $30 \mu \mathrm{l}$ por cavidade do antígeno homólogo ou heterólogo ao anticorpo avaliado, além dos controles negativos.

Proteinas recombinantes do P.falciparum e P.vivax, peptídeos sintéticos e esporozoítas do $P$. malariae e P.vivax VK247 e esporozoitas do P.cynomolgi e P.berghei foram empregadas. Os testes foram feitos em duplicata. 


\subsubsection{Determinação do limiar de reatividade do ELISA para os} anofelinos

O limiar de reatividade do teste imunoenzimático foi definido para cada uma das espécies de plasmódios estudadas, a partir de 100 fêmeas de An. stephensi criadas em laboratório, não infectadas, empregando-se a seguinte fórmula.

C.O. $=X+3 S D$

onde: $X$ é a média aritmética do nivel de absorbância.

\subsubsection{Descrição do ELISA para anofelinos}

O material a ser analisado no ELISA consistiu de mosquitos fêmeas que foram triturados individualmente utilizando-se motor elétrico com ponta de plástico, em $50 \mu$ de solução de PBS pH 7,2 contendo albumina bovina a $1 \%$, Nonidet $\mathrm{P} 40(0,5 \%)$ e os inibidores de protease antipaína $(25 \mu \mathrm{l} / \mathrm{ml})$, leupeptina $(25 \mathrm{mg} / \mathrm{ml})$ e aprotinina $(1,7$ unidades $/ \mathrm{ml})$. A cada tubo de triturado foram acrescentadas $150 \mu$ de solução de PBS pH 7,2 contendo BSA $0,25 \%$, e o material foi mantido a $-20^{\circ} \mathrm{C}$ até ser processado. Todo o procedimento foi realizado em banho de gelo.

Para executar o ELISA foram utilizadas placas de microtitulação de PVC (Dynatech Laboratories, Chantilly, Virginia, USA) sensibilizadas por 15 horas a $4^{\circ} \mathrm{C}$ com $50 \mu$ l de anticorpo monoclonal (AcMo) em PBS pH 7,2, cuja concentração ideal foi previamente determinada. Após cinco lavagens com solução de PBS pH 7,2 contendo 0,05\% de Tween 20 (PBS-T), as placas foram bloqueadas com $150 \mu$ l de PBS-T20, BSA 5\%, permanecendo por um periodo de duas horas a $37^{\circ} \mathrm{C}$, em câmara úmida. 
Após novo ciclo de lavagens com PBS-T, foram adicionados $30 \mu \mathrm{l}$, da suspensão de mosquitos previamente triturados com nova incubação a $37^{\circ} \mathrm{C}$ por uma hora em câmara úmida. Em seguida, as placas foram submetidas a um novo ciclo de lavagens e $50 \mu \mathrm{l}$ do AcMo biotinilado previamente titulado na concentração adequada, foram adicionados em cada uma das cavidades da placa, permanecendo em câmara úmida, durante o período de duas horas à temperatura de $37^{\circ} \mathrm{C}$. Em cada reação, foram utilizados antígenos padrões positivos e controles negativos.

O mesmo procedimento quanto às lavagens foi novamente realizado, adicionando-se, em seguida, $50 \mu$ le conjugado peroxidase ligados a estreptoavidina diluidos em PBS-T, BSA 1\% a 1:8000. Após 30 minutos de incubação a $30^{\circ} \mathrm{C}$ em câmara úmida, as placas foram lavadas três vezes em solução de PBS-T e três vezes em água destilada, adicionando-se a seguir $50 \mu \mathrm{l}$ da mistura cromógena ABTS. Após 30 minutos, à temperatura ambiente, a reação enzimática foi interrompida pela adição de $50 \mu$ lde SDS a $20 \%$ em água destilada. Os valores de absorbância foram obtidos depois da leitura das reações a $414 \mathrm{~nm}$ em leitor de ELISA (MULTISKAN $\mathrm{MCC} / 340 \mathrm{P})$.

Os volumes acima referidos correspondem ao volume em cada cavidade da placa de ELISA.

\subsection{Mótodos estatísticos}

Os dados epidemiológicos foram organizados em um banco de dados (Dbase III) e posteriormente processados e analisados em um programa de Epidemiologia e Estatistica (EPI INFO 6.0).

A análise estatistica dos dados foi realizada utilizando-se o programa GraphPad-Prism, versão 3.0. Utilizamos o teste não paramétrico de KruskalWallis. As análises entre frequências foram feitas pelo teste de Qui-quadrado $\left(X^{2}\right)$ com correção de Yates. 


\section{RESULTADOS}

\subsection{Resultados da população humana}

\subsubsection{Resultados das Informações Epidemiológicas}

Em relação a estratificação etária da população (tabela 10) observamos que dos 163 indivíduos participantes, $67(41,1 \%)$ eram do sexo feminino e 96 $(58,9 \%)$ masculino, sendo que $101(61,96 \%)$ eram menores de 20 anos de idade.

Tabela 10 : Distribuição por faixa etária e sexo dos individuos entrevistados na região do rio Matapi, Amapá, março de 2000.

\begin{tabular}{|c|c|c|c|c|}
\hline \multirow[b]{2}{*}{ IDADE } & \multicolumn{2}{|c|}{ SEXO } & \multirow[b]{2}{*}{ TOTAL } & \multirow[b]{2}{*}{$\%$} \\
\hline & Feminino & Masculino & & \\
\hline $01-04$ & 09 & 10 & 17 & $\overline{10,4}$ \\
\hline $05-09$ & 11 & 27 & 36 & 22.0 \\
\hline $10-14$ & 17 & 17 & 34 & 20.8 \\
\hline $15-19$ & $\overline{04}$ & 10 & $\overline{14}$ & 8.5 \\
\hline $20-24$ & 01 & 03 & 04 & 2,4 \\
\hline $25-29$ & 06 & 01 & 07 & 4,2 \\
\hline $30-34$ & $\overline{04}$ & 04 & 08 & 4,9 \\
\hline $35-39$ & 02 & 05 & 07 & 4,2 \\
\hline $40-44$ & 04 & 04 & 08 & 4,9 \\
\hline $45-49$ & 02 & 08 & 10 & 6,1 \\
\hline $50-54$ & 02 & 01 & 03 & 1,8 \\
\hline $55-59$ & 01 & 03 & 04 & 2,4 \\
\hline $60-64$ & 01 & 00 & 01 & 0,6 \\
\hline $65-69$ & 01 & 00 & 01 & 0,6 \\
\hline$>69$ & 01 & 00 & 01 & 0.6 \\
\hline Năo sabe a idade & 01 & 03 & 04 & 2,4 \\
\hline TOTAL & 67 & 96 & 163 & 100,0 \\
\hline
\end{tabular}


A tabela 11 apresenta as principais atividades econômicas desenvolvida pela população. A ocupação mais encontrada refere-se às atividades agricolas, exercidas por 23 pessoas $(14,1 \%)$, seguida pelas donas de casa $7(4,29 \%)$. A grande maioria dos entrevistados $122(74,8 \%)$ não declarou nenhuma ocupação por tratar-se de individuos menores de idade ou idosos.

Tabela 11: Atividades econômicas desenvolvidas pela população residente na região do rio Matapi, Amapá, março 2000.

\begin{tabular}{l|c|c}
\hline \multicolumn{1}{c|}{ Ocupação } & Frequência & $\%$ \\
\hline Agricultor & 23 & 14,1 \\
\hline Barqueiro & 01 & 0,6 \\
\hline Carpinteiro & 01 & 0,6 \\
\hline Caseiro & 02 & 1,2 \\
\hline Dona de casa & 07 & 4,2 \\
\hline Dono de pesqueiro & 01 & 0,6 \\
\hline Professor & 03 & 1,8 \\
\hline Servente & 01 & 0,6 \\
\hline Trabalhador braçal & 01 & 0,6 \\
\hline Vaqueiro & 01 & 0,6 \\
\hline Nåo desenvolve & 122 & 74,8 \\
\hline atividade econômica & $\mathbf{1 6 3}$ & $\mathbf{1 0 0 , 0}$ \\
\hline \multicolumn{1}{c|}{ TOTAL } & &
\end{tabular}


No que diz respeito a distribuição dos indivíduos por localidade, 40 $(24,54 \%)$, residiam em São João, 74 (45,40\%) em São Raimundo e 49 $(30,06 \%)$ em Santo Antônio. Somente três dos entrevistados eram procedentes de outras regiōes. Tratavam-se dos professores das três localidades. Um, era proveniente de Pernambuco e duas do Municipio de Macapá, AP.

No tocante ao conhecimento da malária, toda a população conhecia o meio de transmissão natural da doença, os sintomas e as possiveis formas de evitar o contato com o vetor.

O emprego de medidas profiláticas foi visto em $87,2 \%$ dos moradores protegidos por mosquiteiros em suas redes de dormir. Uma única familia colocou tela contra insetos na janela e porta da casa. Nenhum membro da comunidade mencionou utilizar quimioprofilaxia. O motivo alegado para a falta de mosquiteiros junto aos demais moradores deveu-se ao seu alto custo. cerca de trinta reais (na época de estudo).

A presença de malána anterior foi relatada por 86 individuos $(52,76 \%)$, sendo que $73,3 \%$ disseram terem contraído a doença nos últimos seis meses. Os demais foram acometidos há mais de cinco anos. Cerca de $10 \%$ das pessoas relataram, cada uma, 10 ou mais episódios de malánia. Pouco acima da metade das pessoas $(52,8 \%)$ conhecia a espécie de Plasmodium que as haviam acometido: $P$. vivax $(70 \%)$ e P.falciparum (30\%). Dos entrevistados, $76,7 \%$ obtiveram diagnóstico pro meio da Fundação Nacional da Saúde. Os demais desconheciam o serviço de saúde que realizou o diagnóstico 
Ao analisarmos a movimentação da população das três localidades, verificamos que raramente as pessoas se deslocam para lugares mais afastados. Eventualmente um morador se dirige ao município de Santana para fazer compras ou ir ao hospital. O principal motivo que dificulta o deslocamento é a falta de meio de transporte na região

Com exceção das crianças, toda a população entra na mata para desenvolver alguma atividade, seja de caça, extração vegetal para alimentação diária ou, no caso dos homens, para lidar com a criação de búfalos. As crianças maiores de cinco anos entram na mata para caçar passarinhos e pegar frutas.

As atividades de lazer citadas pela população resumem-se em freqüentar a igreja ou ir a um pequeno bar situado em São Raimundo. As crianças brincam no peri-domicilio à beira do rio. 
6.1.2.1. Resultados da gota espessa e do esfregaço sangüíneo

Os resultados do exame da gota espessa e do esfregaço sangüineo dos 163 indivíduos pesquisados, revelaram 14 casos positivos para malária. Sete deles, causados por $P$. falciparum, seis pelo $P$. vivax e um malária associada ( $P$. falciparum + P.vivax), conforme mostra a tabela 12 .

Tabela 12: Resultado do teste da gota espessa e esfregaço sangüíneo da população residente nas localidades de Săo Raimundo de Pirativa, São Joăo e Santo António, Amapá, março 2000.

\begin{tabular}{c|c|c|c}
\hline \multicolumn{3}{c}{ Espécios do Plasmodium } \\
\hline Localidades & $P$. falciparum & P. vivax & P.f + P.v \\
\hline $\begin{array}{c}\text { Săo Raimundo } \\
(n=74)\end{array}$ & $2 / 74(2,70 \%)$ & $4 / 74(5,40$ & $0(0,0 \%)$ \\
\hline $\begin{array}{c}\text { São João } \\
(n=40)\end{array}$ & $2 / 40(5,00 \%)$ & $1 / 40(2,50 \%)$ & $1 / 40(2,5 \%)$ \\
\hline $\begin{array}{c}\text { Santo Antônio } \\
(n=49)\end{array}$ & $3 / 49(6,12 \%)$ & $1 / 49(2,00 \%)$ & $0(0,0 \%)$ \\
\hline \begin{tabular}{c} 
Total (n=163) \\
\hline
\end{tabular} & $7 / 163(4,29 \%)$ & $6 / 163(3,68)$ & $1 / 163(0,61 \%)$ \\
\hline
\end{tabular}

$$
\text { P.f. }+ \text { P.v }=\text { P.falciparum }+ \text { P.vivax }
$$


As parasitemias dos pacientes das três localidades estão mostradas na tabela 13. Dentre os seis acometidos pelo $P$. vivax apenas um, relatou algum sintoma de malária. No caso do $P$. falciparum, quatro apresentaram sintomas.

Tabela 13: Resultado das parasitemias obtidas no teste da gota espessa da populaçăo residente nas localidades de São Raimundo, São João e Santo Antônio, Amapá, março 2000.

\begin{tabular}{|c|c|c|}
\hline \multicolumn{3}{|c|}{ Espécies de Plasmodium } \\
\hline $\begin{array}{l}\text { Localidadel } \\
\text { Identificação do } \\
\text { paciente }\end{array}$ & P. falciparum & P. vivax \\
\hline \multicolumn{3}{|l|}{ Săo Raimundo } \\
\hline Paciente 1 & $\begin{array}{c}24.640 \text { parasitas } / \\
\mathrm{mm}^{3} \text { sangue }\end{array}$ & $(-)$ \\
\hline Paciente 2 & $\begin{array}{c}32.380 \text { parasitas } / \\
\mathrm{mm}^{3}\end{array}$ & $(-)$ \\
\hline Paciente 3 & $(-)$ & $(++)$ \\
\hline Paciente 4 & $(-1)$ & $(+)$ \\
\hline Paciente 5 & $(-)$ & $(+++)$ \\
\hline Paciente 6 & $(-)$ & $(++)$ \\
\hline \multicolumn{3}{|l|}{ Săo Joăo } \\
\hline Paciente 7 & $\begin{array}{c}15.000 \text { Parasitas/ } \\
\mathrm{mm}^{3} \text { sangue }\end{array}$ & $(-)$ \\
\hline Paciente 8 & $\begin{array}{c}6.000 \text { Parasitas/ } \\
\mathrm{mm}^{3} \text { sangue }\end{array}$ & $(-)$ \\
\hline Paciente 9 & $(-)$ & $(++)$ \\
\hline Paciente 10 & $\begin{array}{c}2.400 \text { Parasitas/ } \\
\mathrm{mm}^{3} \text { sangue }\end{array}$ & $(+)$ \\
\hline \multicolumn{3}{|l|}{ Santo António } \\
\hline Paciente 11 & $\begin{array}{c}64.240 \text { Parasitas/ } \\
\mathrm{mm}^{3} \text { sangue }\end{array}$ & $(-)$ \\
\hline Paciente 12 & $\begin{array}{c}\text { 43.000 Parasitas/ } \\
\mathrm{mm}^{3} \text { sangue }\end{array}$ & $(-)$ \\
\hline Paciente 13 & $\begin{array}{c}\text { 1.280 Parasitas/ } \\
\mathrm{mm}^{3} \text { sangue }\end{array}$ & $(-)$ \\
\hline Paciente 14 & $(-)$ & $(t+)$ \\
\hline
\end{tabular}

(-) Nogativo 


\subsubsection{Resultados dos testes Imunológicos com os soros}

\subsubsection{Resultados da Reação de Imunofluorescência Indireta}

As freqüências com antígenos de $P$. vivax para anticorpos das classes IgG e IgM, respectivamente foram: em Santo Antonio 70,8\% (17/24) e 20,0\% (5/24), em S. João $50,0 \%(07 / 14)$ e $14,3 \%(2 / 14)$ e na localidade de $S$. Raimundo $80,0 \%$ (28/35) e $11,42 \%$ (4/35). Em relação as prevalências dos anticorpos das classes $\lg \mathrm{g}$ e $\operatorname{lgM}$ do $P$. falciparum, obtivemos: Santo Antonio $29,1 \%(7 / 24)$ e $20,8 \%(5 / 24)$, S. João $28,6 \%(4 / 14)$ e $14,3 \%(2 / 14)$ e São Raimundo $80 \%(28 / 35)$ e $14,3 \%(5 / 35)$. (tabela 14$)$

Tabela 14: Prevaléncia de anticorpos da classe lgG e lgM contra antigenos de formas sangüineas (assexuadas) de P.vivax $\theta$ P.falciparum para o teste de Imunofluorescência Indireta (IFI) com soros das populações de São Raimundo de Pirativa, São João e Santo António, estado do Amapá, março de 2000.

\begin{tabular}{|c|c|c|c|c|}
\hline \multicolumn{5}{|c|}{ ANTIGENOS } \\
\hline & \multicolumn{2}{|c|}{ Imunoglobulina lgG } & \multicolumn{2}{|c|}{ Imunoglobulina IgM } \\
\hline LOCALIDADES & P.vivax & P.falciparum & P.vivax & P.falciparum \\
\hline $\begin{array}{l}\text { Santo Antonio } \\
(n=24)\end{array}$ & $\begin{array}{l}70,8 \% \\
(17 / 24)\end{array}$ & $\begin{array}{l}29,1 \% \\
(7 / 24)\end{array}$ & $\begin{array}{l}20,8 \% \\
(05 / 24)\end{array}$ & $\begin{array}{l}20,8 \% \\
(5 / 24)\end{array}$ \\
\hline $\begin{array}{c}\text { Săo Joăo } \\
(n=14)\end{array}$ & $\begin{array}{l}50,0 \% \\
(07 / 14)\end{array}$ & $\begin{array}{l}28,6 \% \\
(04 / 14)\end{array}$ & $\begin{array}{l}14,3 \% \\
(02 / 14)\end{array}$ & $\begin{array}{l}14,3 \% \\
(02 / 14)\end{array}$ \\
\hline $\begin{array}{c}\text { Săo Raimundo } \\
(n=35)\end{array}$ & $\begin{array}{l}80,0 \% \\
(28 / 35)\end{array}$ & $\begin{array}{l}31,4 \% \\
(11 / 35)\end{array}$ & $\begin{array}{c}11,4 \\
(04 / 35)\end{array}$ & $\begin{array}{l}14,3 \% \\
(05 / 35)\end{array}$ \\
\hline $\begin{array}{l}\text { TOTAL } \\
(n=73)\end{array}$ & $\begin{array}{l}71,2 \% \\
(62 / 73)\end{array}$ & $\begin{array}{l}30,1 \% \\
(22 / 73)\end{array}$ & $\begin{array}{l}16,0 \% \\
(11 / 73)\end{array}$ & $\begin{array}{l}16,4 \% \\
(12 / 73)\end{array}$ \\
\hline
\end{tabular}


Figura 8 : Distribuição dos títulos das reações de IFI para anticorpos IgG e IgM de $P$. falciparum e $P$. vivax da população residente na região do rio Matapi, março 2000.

Figura 8

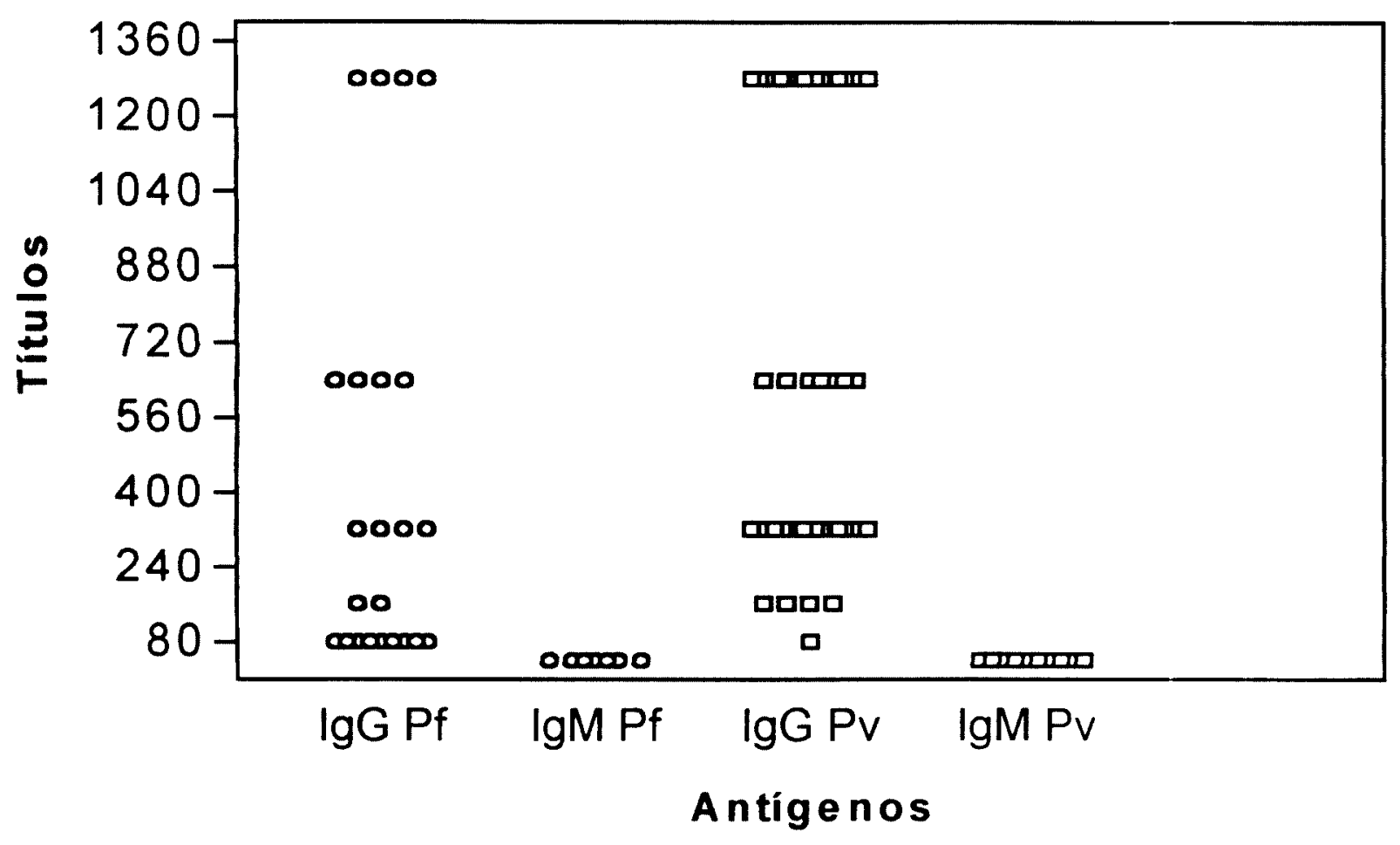




\subsubsection{Resultado do ELISA com os soros humanos}

As prevalências totais de reações positivas para a proteina CS em ELISA calculadas a partir dos limiares de reatividade obtidos com 30 amostras de soros de área endêmica de malária foram: P.vivax $38,4 \%$ (28/73), P.falciparum 26\% (19/73), P.malariae 36,7\% (27/73), P.vivax VK $24720,5 \%$ (15/73) e P.vivax like 17,8\% (13/73).

Os resultados obtidos a partir dos limiares de reatividade usando soros de Banco de Sangue de São Paulo foram: P.vivax 45,2\% (33/73), P.falciparum 43,8\% (32/73), P.malariae 49,3\% (36/73), P.vivax VK 247 $36,9 \%(27 / 73)$ e P.vivax like $28,7 \%(21 / 73)$.

Conforme o esperado as prevalências obtidas com os limiares estabelecidos com os soros do Banco de Sangue de São Paulo foram mais elevadas do que com os soros de área endêmica. Consideramos em nossa análise final de prevalências, os limiares estabelecidos com soros de área endêmica e a média das absorbâncias acrescida de três desvios padrão.

$\mathrm{Na}$ tabela 15 estão demonstradas as freqüências de anticorpos da classe IgG contra a região repetitiva da proteína CS para os cinco peptídeos com os 73 soros testados das três localidades trabalhadas. 
Tabola 15: Prevalência de anticorpos da classe lgG contra região repetitiva da Protoina CS de $P$. vivax, $P$. falciparum, $P$. malariae, $P$. vivax VK247 • P. vivax like, da população residente em São Raimundo de Pirativa, Săo Joăo e Santo Antonio, março de 2000.

\begin{tabular}{|c|c|c|c|c|c|}
\hline & \multicolumn{5}{|c|}{ ANTIIGENOS } \\
\hline & P. vivax & P.falciparum & $\begin{array}{c}P . \\
\text { malariae }\end{array}$ & $\begin{array}{l}\text { P. vivax } \\
\text { VK247 }\end{array}$ & $\begin{array}{c}P \text { P.vivax } \\
\text { like }\end{array}$ \\
\hline \multicolumn{6}{|l|}{ AMOSTRAS } \\
\hline $\begin{array}{c}\text { São Raimundo } \\
(n=35)\end{array}$ & $\begin{array}{l}31,4 \% \\
(11 / 35)\end{array}$ & $\begin{array}{l}14,3 \% \\
(05 / 35)\end{array}$ & $\begin{array}{l}31,4 \% \\
(11 / 35)\end{array}$ & $\begin{array}{l}22,9 \% \\
(08 / 35)\end{array}$ & $\begin{array}{l}20,0 \% \\
(07 / 35)\end{array}$ \\
\hline $\begin{array}{c}\text { Santo António } \\
(n=24)\end{array}$ & $\begin{array}{l}50,0 \% \\
(12 / 24)\end{array}$ & $\begin{array}{l}41,7 \% \\
(10 / 24)\end{array}$ & $\begin{array}{l}37,5 \% \\
(9 / 24)\end{array}$ & $\begin{array}{c}16,7 \% \\
(04 / 24)\end{array}$ & $\begin{array}{l}25,0 \% \\
(06 / 24)\end{array}$ \\
\hline $\begin{array}{c}\text { São João } \\
(n=14)\end{array}$ & $\begin{array}{l}35,7 \% \\
(05 / 14)\end{array}$ & $\begin{array}{l}28,6 \% \\
(04 / 14)\end{array}$ & $\begin{array}{l}50,0 \% \\
(07 / 14)\end{array}$ & $\begin{array}{l}21,4 \% \\
(03 / 14)\end{array}$ & $\begin{array}{c}0 \% \\
(0 / 14)\end{array}$ \\
\hline $\begin{array}{l}\text { TOTAL } \\
(n=73)\end{array}$ & $\begin{array}{l}38,4 \% \\
(28 / 73)\end{array}$ & $\begin{array}{l}26,0 \% \\
(19 / 73)\end{array}$ & $\begin{array}{l}36,9 \% \\
(27 / 73)\end{array}$ & $\begin{array}{r}20,5 \% \\
(15 / 73)\end{array}$ & $\begin{array}{r}17,8 \% \\
(13 / 73)\end{array}$ \\
\hline
\end{tabular}

P.vivax : Limiar de reatividade 0,138 .

$P$.falciparum: Limiar de reatividade 0,133 .

P.malariae: Limiar de reatividade 0,133 .

P.vivax (VK247): Limiar de reatividade 0,152.

P.vivax-like: Limiar de reatividade 0,239. 
Apesar do número de amostras positivas ser pequeno, comparamos as possiveis diferenças em relação as absorbâncias obtidas nos soros dos individuos, para as diferentes espécies de Plasmodium, nas três localidades por nós trabalhada.

Embora alguns soros tenham apresentado absorbâncias mais elevada para um dado peptídeo numa determinada localidade em relação à outra, nenhuma diferença estatisticamente significante foi encontrada. Exceto em relação à soropositividade de P.malariae nos soros coletados em São João e do $P$. falciparum em Santo Antônio ( $p<0.05)$.

Nas figuras 910 e 11 verificamos a distribuição das absorbâncias obtidas com os soros testados pelo ELISA com cada um dos peptideos nas três comunidades estudadas. 
Figura 9. Distribuição das absorbâncias obtidas om ELISA à $414 \mathrm{~nm}$ com os poptidoos CS de P. falciparum (Pf), P. vivax (Pv), P. malariae (Pm), P.vivax VK 247 (PVK) • P. vivax like para a população de São Raimundo, Amapá - Março 2000.

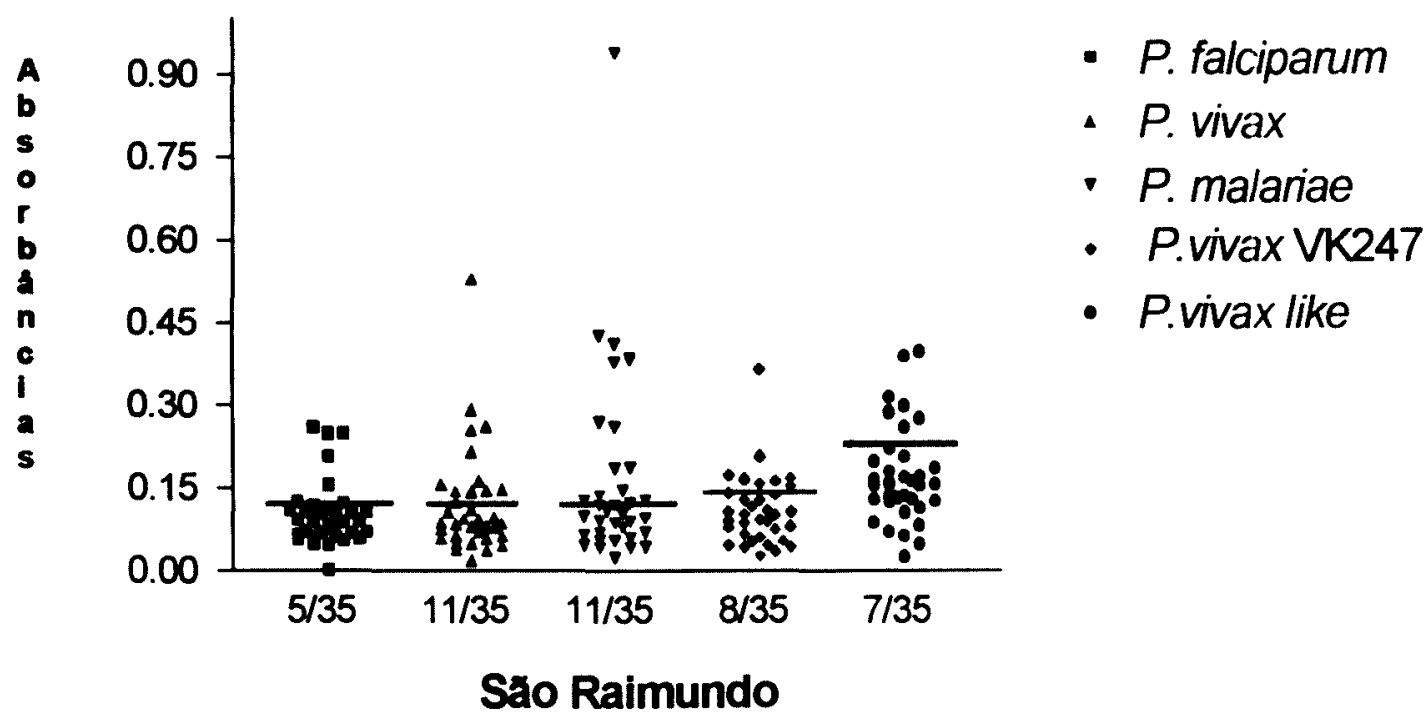

As barras indicam o limiar do reatividade para cada peptidoo.

P.falciparum: 0,138.

P.vivax o P.malariae: 0,133.

P.vivax VK 247: 0,152.

P.vivax like: 0,239. 
Figura 10: Distribuição das absorbâncias a $414 \mathrm{~nm}$ obtidas em ELISA com soros da população de São João, Amapá - Março 2000.

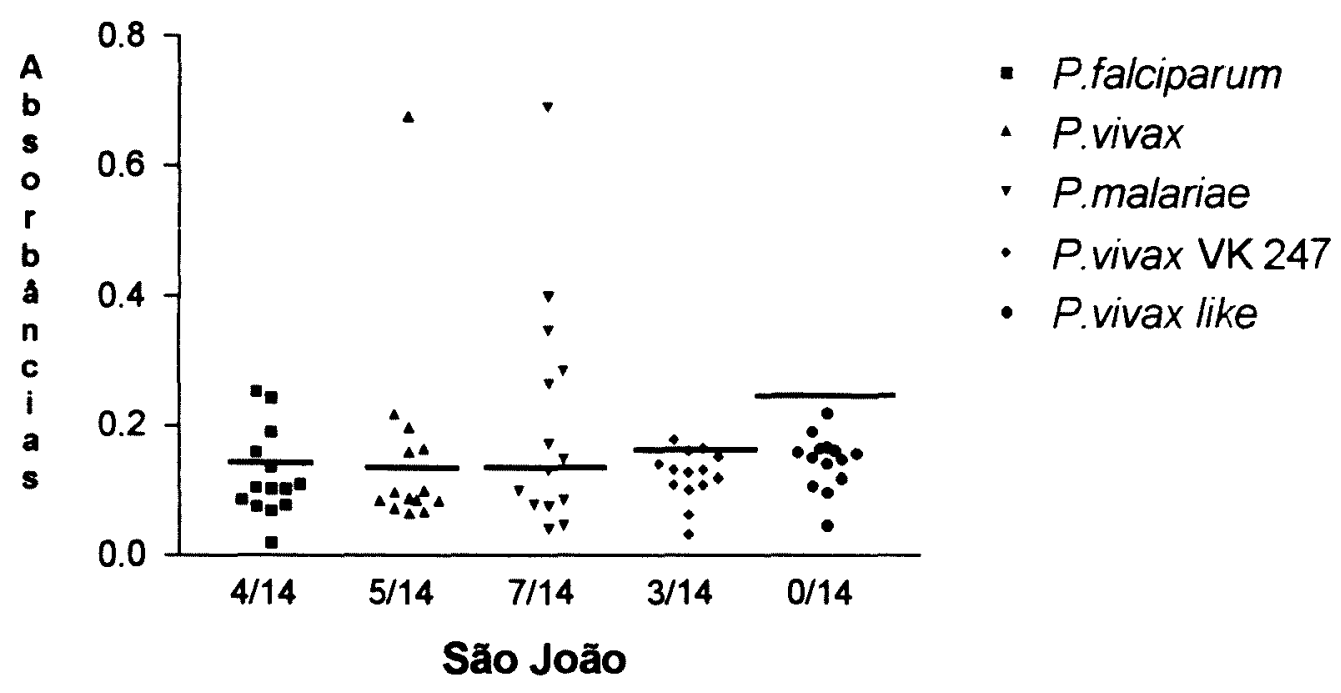

As barras indicam o limiar de reatividade para cada peptídeo.

P.falciparum: 0,133; P.vivax e P.malariae: 0,133; P.vivax VK 247: 0,152 e P.vivax like: 0,239 . 
Figura 11: Distribuição das absorbâncias a $414 \mathrm{~nm}$ obtidas em ELISA com soros da população de Santo Antônio, Amapá - Março 2000.

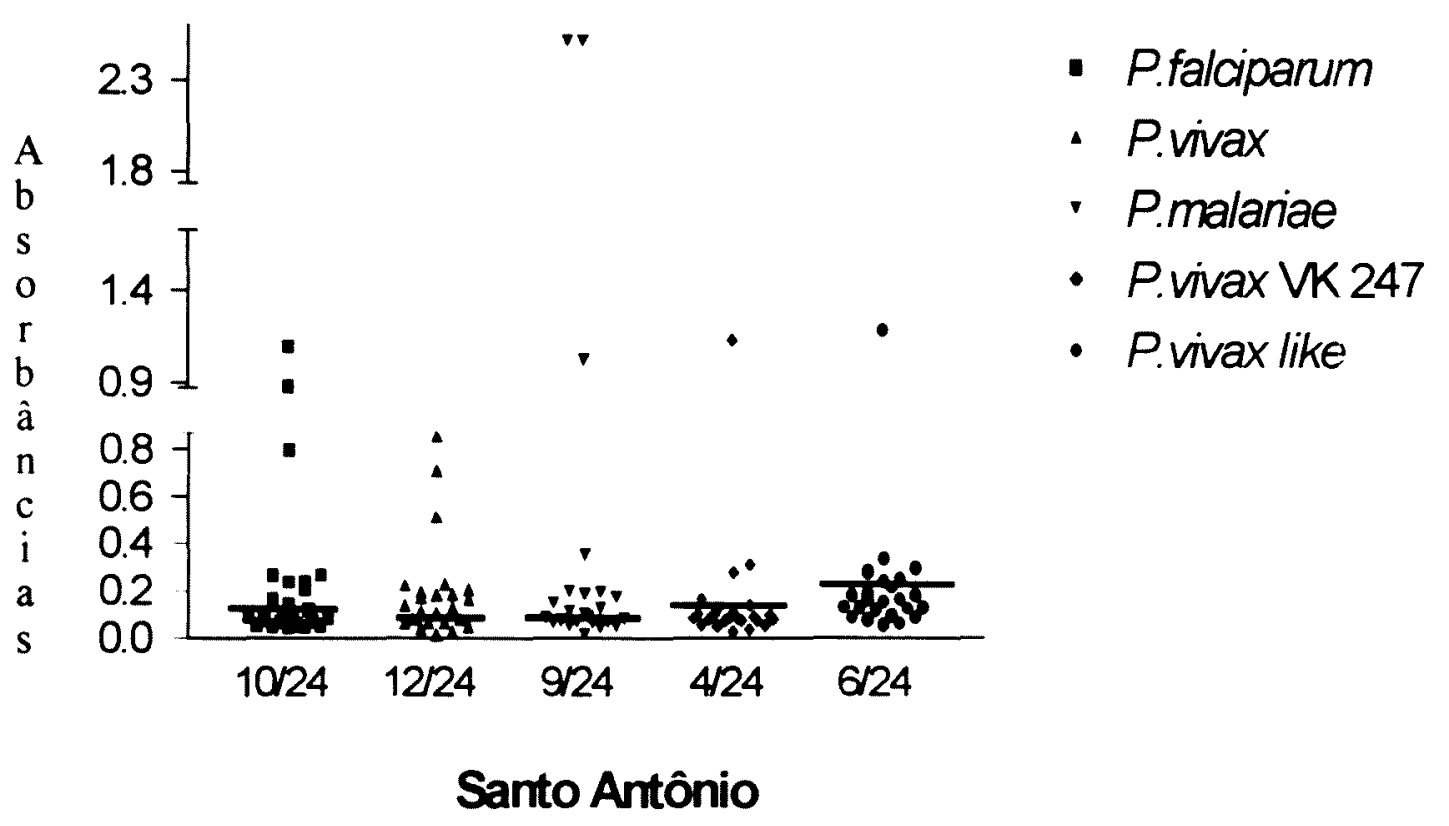

As barras indicam o limiar de reatividade para cada peptideo.

P. falciparum: 0,133; P vivax e P malariae: 0,133; P vivax VK 247:0,152 e

P. vivax like: 0,239 


\subsection{Resultados do estudo entomológico}

\subsubsection{Coleta e identificação dos anofelinos}

Os anofelinos foram obtidos por meio de capturas entomológicas em ambiente intradomiciliar e peridomiciliar, empregando-se a técnica de isca humana, visando a obtenção de dados para caracterização dos vetores possivelmente envolvidos na transmissão da malária local.

As coletas foram realizadas no período compreendido entre os meses de maio a novembro de 1999 em três localidades situadas ao longo do Rio Matapi, São Raimundo do Pirativa, Santo Antonio e São João, em 3 dias consecutivos, uma vez por mês, por 13 horas.

As espécies mais abundantes foram An. darlingi e An. albitarsis., (cerca de $95 \%$ dos anofelinos capturados), as demais espécies foram An.oswaldoi, An. braziliensis, An. nuneztovari e An triannulatus.

Em relação ao An. albitarsis, embora não tenhamos realizado uma análise molecular dos espécimes para a verificação exata de cada membro do complexo assim, ao ser citado o termo An albitarsis, trata-se do An albitarsis s.l. que possivelmente trata-se do An. marajoara, tendo em vista os trabalhos realizados no estado do Amapá por SEGURA 1998, porém é necessário uma avaliação criteriosa, para comprovar esta informação.

Os dados apresentados na tabela 28 , referem-se a distribuição do $A n$. daningi e An. albitarsis, capturados no periodo de maio a outubro de 1999 nas localidades de São Raimundo de Pirativa, São João e Santo Antônio. Município de Santana, Amapá. 
Tabela 16: Distribuição do An. darlingi e An. albitarsis, capturados em três capturas consecutivas no período de maio a outubro de 1999 na região do rio Matapi, Amapá.

\begin{tabular}{|c|c|c|c|c|}
\hline $\begin{array}{l}\text { Data das } \\
\text { Coletas }\end{array}$ & An.darlingi & An.. albitarsis & $\begin{array}{c}\text { An. darlingi } \\
\text { Total }\end{array}$ & $\begin{array}{c}\text { An. } \\
\text { albitarsis } \\
\text { Total }\end{array}$ \\
\hline $4 / 5 / 99$ & 49 & 657 & \multirow{3}{*}{229} & \multirow{3}{*}{1.500} \\
\hline $5 / 5 / 99$ & 107 & 481 & & \\
\hline $6 / 5 / 99$ & 73 & 362 & & \\
\hline $31 / 5 / 99$ & 429 & 316 & \multirow{3}{*}{1.436} & \multirow{3}{*}{1.709} \\
\hline $1 / 6 / 99$ & 483 & 412 & & \\
\hline $2 / 6 / 99$ & 524 & 981 & & \\
\hline $30 / 6 / 99$ & 1001 & 256 & \multirow{3}{*}{3.320} & \multirow{3}{*}{734} \\
\hline $1 / 7 / 99$ & 1040 & 269 & & \\
\hline $2 / 7 / 99$ & 1279 & 209 & & \\
\hline $28 / 7 / 99$ & 2724 & 281 & \multirow{3}{*}{7.908} & \multirow{3}{*}{656} \\
\hline $29 / 7 / 99$ & 2425 & 189 & & \\
\hline $30 / 7 / 99$ & 2759 & 186 & & \\
\hline $30 / 8 / 99$ & 958 & 72 & \multirow{3}{*}{2.823} & \multirow{3}{*}{366} \\
\hline $31 / 8 / 99$ & 948 & 133 & & \\
\hline $1 / 9 / 99$ & 917 & 161 & & \\
\hline $27 / 9 / 99$ & 760 & 119 & \multirow{3}{*}{2.152} & \multirow{3}{*}{438} \\
\hline $28 / 9 / 99$ & 779 & 181 & & \\
\hline $29 / 9 / 99$ & 613 & 138 & & \\
\hline $26 / 10 / 99$ & 664 & 212 & \multirow{3}{*}{1.558} & \multirow{3}{*}{370} \\
\hline $27 / 10 / 99$ & 375 & 87 & & \\
\hline $28 / 10 / 99$ & 519 & 71 & & \\
\hline Total & & & 19.424 & 5.773 \\
\hline
\end{tabular}


Observamos na Tabela 16 que An. dartingi foi a espécie mais capturada ao longo do trabalho, totalizando 19. 424 exemplares, atingindo a maior quantidade no início do mês de julho, às quais totalizaram 7.908 mosquitos nas 3 noites consecutivas. O menor número de exemplares desta espécie, foi capturado no inicio de maio, com somente 229 mosquitos.

Em relação a ocorrência do An.albitarsis foram capturados 5.773 espécimens, no total das capturas, sendo que as maiores abundância foram verificadas no início de maio e junho com 1.500 e 1.709 exemplares, respectivamente. A menor quantidade foi obtida no final de outubro onde se capturou 370 mosquitos

\section{Numero de anofelinos}

capturados na região do rio Matapi, Amapá, no inicio de

\section{cada mês.}

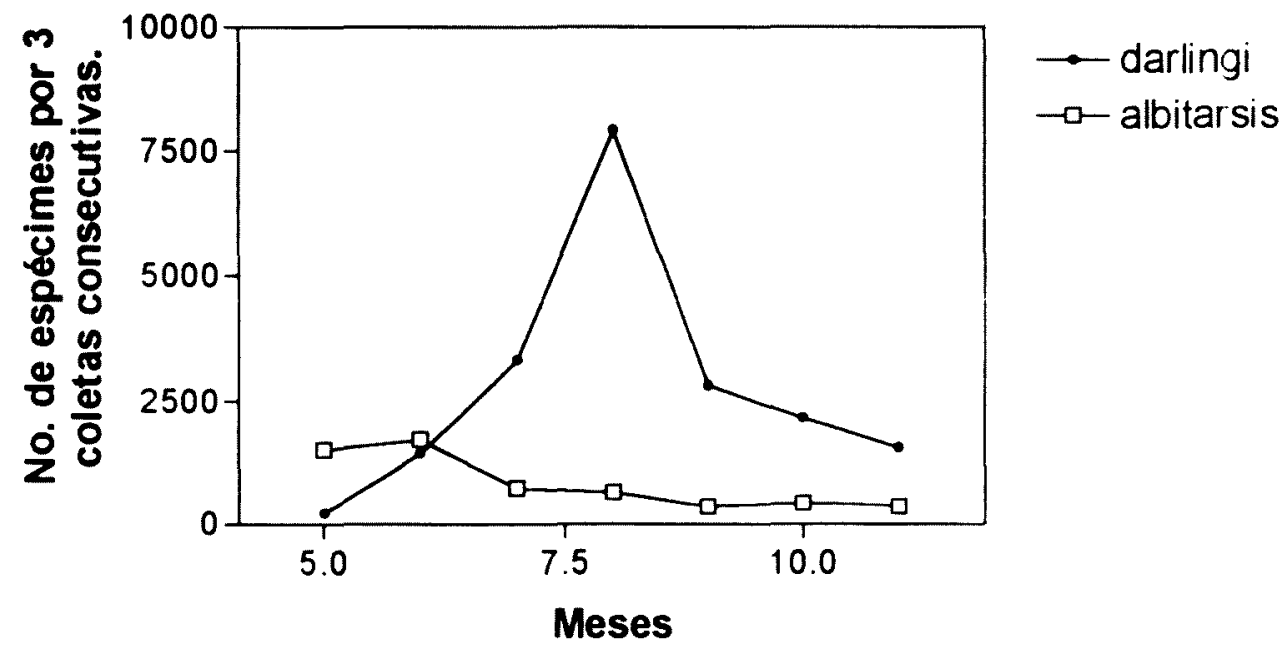

Figura 12 : Distribuição do An. darlingie An. albitarsis, capturados em três capturas consecutivas no período de maio a outubro de 1999 na região do rio Matapi, Amapá. 


\subsubsection{Resultados da padronização do ELISA com os anofelinos}

\subsubsection{Determinação das concentrações ideais dos anticorpos} monoclonais e do conjugado imunoenzimático

Para a escolha das concentrações protéicas ideais dos monoclonais usados para a sensibilização das placas de microtitulação e diluições ótima do conjugado estreptoavidina- peroxidase à ser empregado no ELISA, foram efetuadas as diversas titulações em bloco, testando-se paralelamente as diluições crescentes dos anticorpos monoclonais contra diluições crescentes dos controles positivos e negativos, mantendo-se constantes as concentrações dos anticorpos monoclonais, previamente biotinilados.

A concentração ótima para uso foi de $1,0 \mu \mathrm{g} / \mathrm{ml}$ do monoclonal que era utilizado como anticorpo de captura do antígeno, para os cinco tipos de plasmódios, com o conjugado diluído à $1 / 8000$ para os peptídeos de P.falciparum, P.vivax, P.vivax VK247 e 1/12000 para os peptídeos de P.vivax like e P.malariae.

5.2.2.2. Determinação das concentrações ideais dos antígenos (proteínas recombinantes e peptídeos sintéticos)

Como padrões positivos do ELISA- captura foram utilizados peptídeos sintéticos, proteínas recombinantes ou esporozoítas de plasmódios.

Para $P$. vivax VK 247, empregamos esporozoítas obtidos de $A n$. stephensi e An. dirus na concentração de 50 esporozoítas/ ml. Para $P$ vivax e $P$. falciparum utilizamos proteínas CS recombinantes na concentração de 1,0 $\mu / / \mathrm{ml}$, enquanto que as melhores concentrações obtidas para $P$. malariae/ $P$. brasilianum, com o peptídeo sintético $\left[(\mathrm{NAAG})_{4}\right]_{4}$ foi de $100 \mu \mathrm{g} / \mathrm{m}$. tanto quanto para P. vivax like/ P. simiovale. 


\subsubsection{Testes de especificidade}

Neste teste foram usou-se como antígeno as proteínas recombinantes do P.falcipanum e do $P$.vivax, os peptídeos sintéticos e esporozoítas do $P$. malariae e do P.vivax VK247 e os esporozoítas do P.cynomolgi e P.berghei.

Verificou-se que os niveis de absorbância obtidos foram inferiores ao limiar de positividade da reação, quando se empregou antígeno heterólogo a cada um dos monoclonais. Não foram observadas reações cruzadas entre um monoclonal dirigido à determinada espécie de plasmódio quando colocado para reagir com antígeno CS de espécies heterólogas do parasita.

\subsubsection{Determinação do limiar de reatividade no teste ELISA com} os anofelinos

O limiar de reatividade do ELISA foi calculado para cada plasmódio a partir de 100 mosquitos negativos, criados em insetário, adicionando-se 3 desvios padrões à média aritmética do nível de absorbância, realizados em diferentes ensaios.

C. $O=X+3 S D$

onde: $\mathrm{X}$ é a média aritmética das absorbâncias dos espécimes 
As médias aritméticas das absorbâncias para P.falciparum, P.vivax, P.malaniae, P.vivax VK 247 e $P$. vivaxlike foram, respectivamente, 0.132 , $0,152,0,206,0,182$ e 0,312 com desvio padrão de $0,017,0,024,0,039$, 0,046 e 0.035 . Obtendo os limiares de reatividade de $0,183,0,225,0,323$ e 0,322 e 0,234 , respectivamente.

Tabela 17: Valores do limiar de reatividade para P.falciparum, P.vivax, P.malariae, P.vivax VK247 e P.vivax like, pelo emprego de 100 exemplares de An. stephensi criados em laboratório, não infectados.

\begin{tabular}{c|c|c|c|c|c}
\hline Peptídeos & P. falciparum & P. vivax & P.malariae & $\begin{array}{c}\text { P.vivax } \\
\text { VK247 }\end{array}$ & $\begin{array}{c}\text { P.vivax } \\
\text { like }\end{array}$ \\
\hline Média & 0,132 & 0,152 & 0,206 & 0,182 & 0,312 \\
\hline DP & 0,017 & 0,024 & 0,039 & 0.046 & 0.035 \\
\hline M+3DP & $\mathbf{0 , 1 8 3}$ & $\mathbf{0 , 2 2 5}$ & $\mathbf{0 , 3 2 3}$ & $\mathbf{0 , 3 2 2}$ & $\mathbf{0 , 2 3 4}$ \\
\hline
\end{tabular}

M= Média das absorbâncias

DP= Desvio Padrão 


\subsection{Resultados do ELISA com os anofelinos}

5.3.1. Resultados da infectividade do An. darlingi pelo diferentes Plasmodium

O ELISA para An. darlingi com os cinco tipos de Plasmodium resultou que dos 9.450 An. daningi processados 6 anofelinos foram positivos para 0 P.falcipanum, 11 para P.vivax, 57 para P.vivax VK247, 97 para P.vivax like e 4 para P.malaniae.

Tabela 18: Positividade do An. darlingi infectado por $P$. falciparum, P.vivax, P.vivax VK247, P.vivax/like e P. malariae pelo ELISA, coletados na região do rio Matapi, Amapá no período de maio a outubro de 1999

\section{Espécies de Plasmodium}

\begin{tabular}{c|c|c|c|c|c|c}
\hline & $\begin{array}{c}\text { Número } \\
\text { de } \\
\text { mosquitos } \\
\text { testados }\end{array}$ & P.falciparum & P.vivax & $\begin{array}{c}\text { P.vivax } \\
\text { VK247 }\end{array}$ & $\begin{array}{c}P \text { P. vivax } \\
\text { like }\end{array}$ & $P$. malariae \\
\hline Captura 1 & 150 & 0 & 0 & 0 & 0 & 0 \\
\hline Captura 2 & 1.000 & 3 & 0 & 5 & 9 & 0 \\
\hline Captura 3 & 1.500 & 0 & 3 & 7 & 22 & 0 \\
\hline Captura 4 & 3.000 & 3 & 0 & 9 & 4 & 1 \\
\hline Captura 5 & 1.500 & 0 & 5 & 21 & 20 & 3 \\
\hline Captura 6 & 1.500 & 0 & 3 & 15 & 29 & 0 \\
\hline Captura 7 & 800 & 0 & 0 & 0 & 13 & 0 \\
\hline Total & $\mathbf{9 . 4 5 0}$ & $\mathbf{6}$ & $\mathbf{1 1}$ & $\mathbf{5 7}$ & $\mathbf{9 7}$ & $\mathbf{4}$ \\
\hline
\end{tabular}

Determinado por ELISA utilizando anticorpos monoclonais 2A10 para

P. falciparum, 2F2 para P.vivax, 2E10 para $P$. vivax VK247 e 6B10 para

P. malariae. 
Figura 13

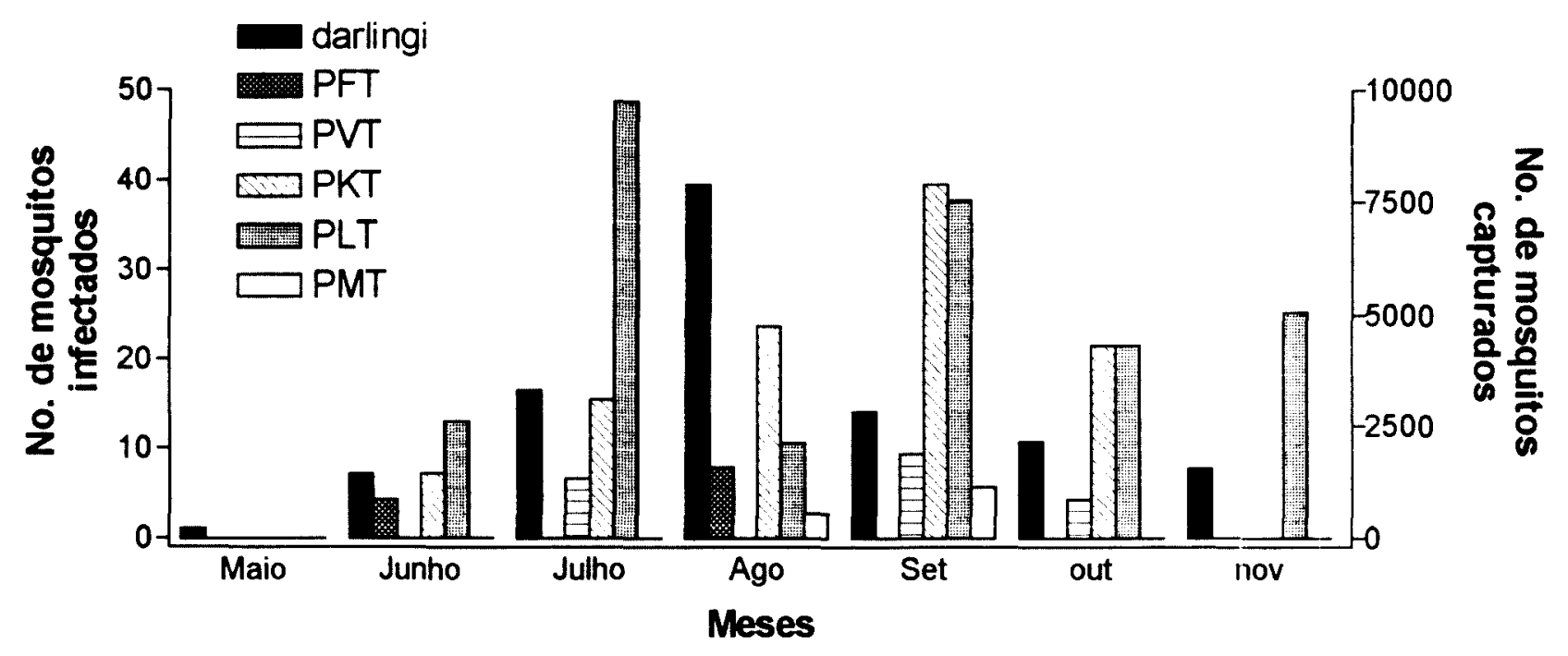

Figura 13: Positividade do An. darlingi infectado mensalmente pelo $P$. falciparum (PFT), P.vivax (PVT), P.vivax VK247 (PKT), P.vivax/like (PLT) e P. malariae (PMT) pelo ELISA, coletados na região do rio Matapi, Amapá, maio a outubro de 1999. 
5.3.2. Resultados da infectividade do An. albitarsis pelos diferentes plasmódios

O ELISA para An. albitarsis com os cinco tipos de Plasmodium resultou que dos $3.523 \mathrm{An}$. albitarsis processados 7 anofelinos foram positivos para o P.falciparum, 4 para P.vivax, 21 para P.vivax VK247, 21 para P. vivax like e 4 para P.malaniae.

\section{Espécies de Plasmodium}

\begin{tabular}{c|c|c|c|c|c|c}
\hline & $\begin{array}{c}\text { Número } \\
\text { de } \\
\text { mosquitos } \\
\text { testados }\end{array}$ & P.falciparum & P.vivax & $\begin{array}{c}\text { P.vivax } \\
\text { VK247 }\end{array}$ & $\begin{array}{c}P . \text { vivax } \\
\text { like }\end{array}$ & $P$. malariae \\
\hline Captura 1 & 762 & 0 & 0 & 7 & 3 & 0 \\
\hline Captura 2 & 762 & 3 & 0 & 5 & 4 & 2 \\
\hline Captura 3 & 700 & 1 & 0 & 0 & 1 & 0 \\
\hline Captura 4 & 599 & 3 & 3 & 3 & 2 & 0 \\
\hline Captura 5 & 200 & 0 & 1 & 2 & 2 & 0 \\
\hline Captura 6 & 250 & 0 & 0 & 4 & 5 & 2 \\
\hline Captura 7 & 250 & 1 & 0 & 0 & 4 & 0 \\
\hline Total & $\mathbf{3 5 2 3}$ & $\mathbf{7}$ & $\mathbf{4}$ & $\mathbf{2 1}$ & $\mathbf{2 1}$ & $\mathbf{4}$ \\
\hline
\end{tabular}

Determinado por ELISA utilizando anticorpos monoclonais 2A10 para P. falciparum, 2F2 para P.vivax, 2E10 para $P$. vivax VK247 e 6B10 para P. malariae. 
Figura 14

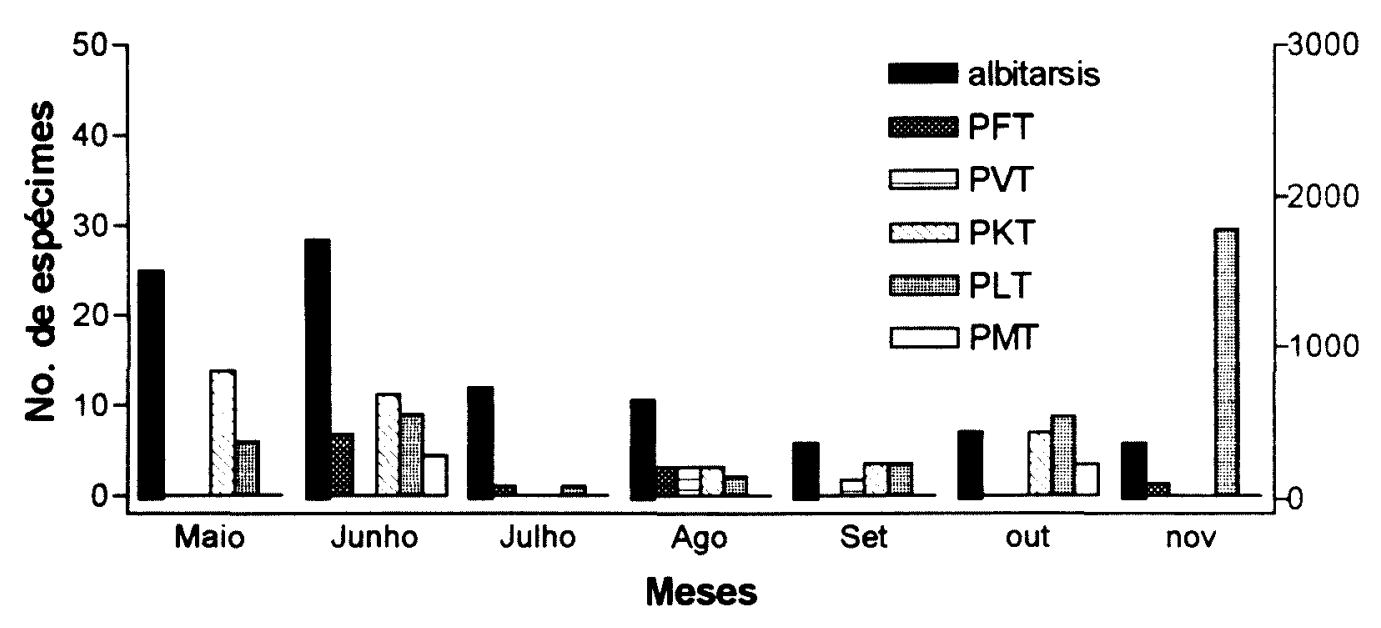

Figura 14: Positividade do An. albitarsis infectado mensalmente pelo $P$. falciparum (PFT), P.vivax (PVT), P.vivax VK247 (PKT), P.vivax/like (PLT) e P. malariae (PMT) pelo ELISA, coletados na região do rio Matapi, Amapá, maio a outubro de 1999. 
Figura 15

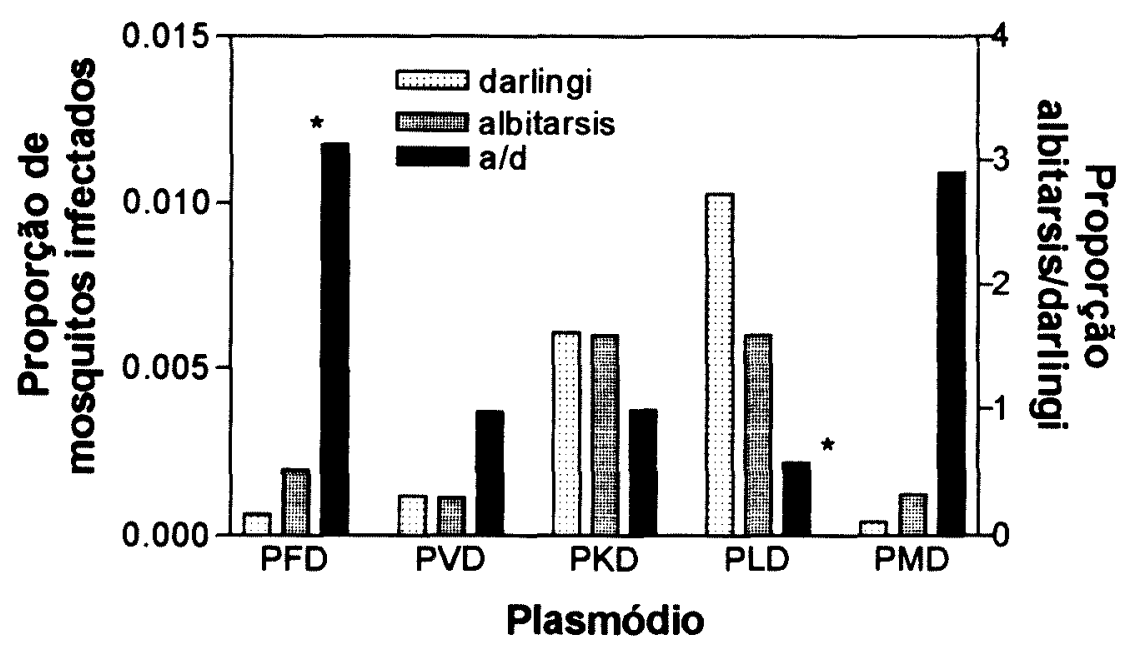

${ }^{*} \mathrm{P}<0.05$

$\mathrm{PF}=P$. falciparum

$\mathrm{PV}=P$. vivax

$\mathrm{PK}=P$. vivax $\mathrm{VK} 247$

$\mathrm{PL}=P$. vivax like

$\mathrm{PM}=P \cdot$ malaniae

Figura 15: Proporção de An. albitarsis e An. darlingi infectados com os diferentes plasmódios em relação ao total de anofelinos processados na região do rio Matapi, AP. 


\section{DISCUSSÃO}

A malária é uma doença complexa cuja transmissão envolve interações entre os parasitas, hospedeiros humanos e animais, vetores e o meio ambiente. O desconhecimento dessas interações e fatores sócioeconômicos e políticos limitam a implementação de um controle efetivo e sustentável.

A atual estratégia no Brasil baseia-se no Plano de Intensificação das Ações de Controle de Malária na Amazônia Legal (FUNASA 2000, vide Introdução, pág. 14). Verifica-se na prática que o programa é mantido basicamente por ações voltadas a aspectos antropocêntricos, por meio do diagnóstico e tratamento precoce de casos sintomáticos, enquanto as atividades direcionadas ao controle dos insetos, quando estabelecidas, baseiam-se exclusivamente na presença de um vetor hipotético.

A presença de malária assintomática causada pelo P.vivax na América do Sul (ANDRADE et. al 1995; ZIMMERMAN e VOORHAM 1997; PAHO 1998), provavelmente relacionada à baixa sensibilidade dos testes laboratoriais (principalmente em pacientes com baixa parasitemia), contribui para a imprecisão dos dados notificados. Por tratarem-se de um sistema de notificação lento, impreciso e centralizado, os serviços de saúde, na maioria das vezes, não oferecerem um nível de qualidade satisfatório o bastante para detectar os casos tão rapidamente quanto o seu surgimento. Sendo assim, possivelmente, a incidência real da malária está subestimada e seu controle negligenciado.

Ao analisarmos o número de casos de malária no Estado do Amapá, verificamos que houve um aumento surpreendente de $85 \%$ na notificação de casos de $P$. vivax a partir de 1993 (figura 1). Voorham (comunicação pessoal) comparou os dados de notificação da área no periodo de junho/1998 a novembro/1999 com o número de lâminas coletadas/mês em relação ao tamanho da população e constatou que o número de casos detectados 
variou consideravelmente. Possivelmente estes dados refletiram negativamente sobre a precisão da notificação da malária neste Estado.

A partir destas considerações, questionamentos mais direcionados à melhoria do diagnóstico foram formulados. Uma das perguntas iniciais do nosso trabalho foi com relação ao sistema de notificação passiva. Seria este sistema adequado para ser utilizado em pesquisas e para monitorar intervenções de controle?

A resposta surgiu a partir dos nossos resultados, obtidos no exame parasitológico por meio de busca ativa. Dentre os 163 indivíduos estudados, surpreendeu-nos o encontro de 14 casos positivos de malária $(P . f n=7, P . v$ $n=6$ e $P f+P \vee n=1)$.

Enquanto os dados de notificação da área mostraram casos esporádicos de $P$. falciparum, em nosso estudo foram encontrados $57 \%$ de casos positivos para esta espécie de plasmódio. Estes resultados nos alertaram sobre a baixa sensibilidade do diagnóstico por meio da busca passiva.

Exemplificando: em nossos estudos, das sete infecções por $P$. falciparum, os dois casos sem sintomatologia clínica, apresentaram parasitemias elevadas ( 43 mil e 64 mil parasitas $/ \mathrm{mm}^{3}$ sangue). Portanto, a dificuldade no registro de notificações de casos de $P$. falciparum evidencia uma deficiência no sistema utilizado para obtenção de dados confiáveis.

Os dados relativos à notificação dos casos de malária ocorridos em 1997 por sexo e faixa etária indicam que naquele ano os valores foram significativamente maiores em homens entre 20 e 49 anos. Em contraste com esta informação, nossos resultados apontam que 12 dos 14 casos detectados durante a busca ativa, envolvem individuos com idade abaixo dos 15 anos. Nossos resultados coincidiram com os relatados por CAMARGO et. al (1999). Estes autores estudaram a epidemiologia da 
malária em Portuchuelo, uma região ribeirinha em Rondônia, e encontraram maior prevalência da doença em crianças, menores de 16 anos.

$\mathrm{Na}$ área por nós trabalhada, a maioria dos indivíduos residentes, relataram ausência de sintomatologia para malária. Este fato pode, eventualmente, relacionar-se com fatores genéticos capazes de influenciar na transmissão da malária, como a ausência de antígenos de superfícic relacionados ao fator Duffy e também à existência das hemoglobinopatias tais como as anemias causadas pela presença da Hemoglobina $S$, entre outras (MONTOYA et. al 1994).

Tendo em vista que a presença desses fenótipos predomina em populaçöes de etnia africana e que as três comunidades onde trabalhamos são constituídas principalmente por membros deste grupo, o reconhecimento da influência de ambos os fatores na incidência da doença, poderiam elucidar alguns aspectos sobre a dinâmica de transmissão local.

No Suriname, a alta freqüência do fenótipo Fy (a-b-) na população residente no interior foi um determinante importante para a distribuição das espécies de plasmódios (VOORHAM et. al 1993). Informações desta natureza são escassas em populações brasileiras. Uma pesquisa sobre estes fenótipos foi realizada por COLAUTO et. al (1981) em população ribeirinha no Estado do Amazonas. O fenótipo Fy (a-b-) foi encontrado em $12 \%$ dos moradores e em $3 \%$ de uma comunidade indigena. Como o objetivo deste trabalho não foi caracterizar os fenótipos destas populaçōes, achamos que seria interessante estudar este aspecto nas populações ribeirinhas descritas por nós como um desdobramento futuro deste trabalho.

Uma vez que os dados obtidos exclusivamente da população humana são contestáveis diante da impossibilidade de correlacionar sintomas clínicos e status parasitológico (BURKOT e GRAVES 1995), o emprego de Parâmetros Entomológicos de Transmissão e o diagnóstico humano poderiam complementar-se mutuamente. Diversos autores demostraram a hipótese da existência de uma relação entre os Parâmetros Entomológicos e 
a incidência da malária (RUBIO-PALIS 1994a; HAY et. al 2000; LINDBLADE et. al 2000).

A potencialidade de um anofelino transmitir malária é estimada baseando-se no modelo de transmissão de MacDonald (MACDONALD 1957), cujos componentes referem-se a: número de picadas por pessoa por dia, antropofilia, duração do ciclo gonotrófico, sobrevivência diária do anofelino e duração do periodo extrínseco de incubação do Plasmodium. Estes fatores definem o modelo clássico de Capacidade Vetorial de GARRETT-JONES (1964) e mede o grau de potencial contato infeccioso (MOLINEAUX 1978).

A Taxa de Inoculação Humana é um dos parâmetros bastante empregados, principalmente na África (BEIER et. al 1994.1999; HAY et al 2000). Outro parâmetro é a relação entre Índice de Antropofilia e Taxa de Esporozoitas (CATTANI et. al 1986), cujo resultado apontou uma relação direta entre as duas variáveis em An. punctulatus. Nas Américas, os trabalhos desta natureza são escassos. A variável mais usada é a que mede a densidade do vetor em relação ao número de mosquitos coletados no ato de pousar para se alimentar no homem (RUBIO-PALIS e CURTIS 1992; ZIMMERMAN 1992).

Até este momento, estamos apenas aferindo a relação entre possiveıs vetores, antropofilia e taxas de infecçāo. Nenhum destes estudos. porém, esclarece-nos sobre a infecção vetorial e sua capacidade e competência de transmitir a doença. Com relação à incriminação vetorial, são empregados métodos capazes de determinar a taxa de esporozoítas (pela dissecção das glândulas salivares ou pelo ELISA) (ZIMMERMAN 1992; BRANQUINHO et. al 1993; CONN et. al in press).

O ELISA utilizado na deteç̧ão da infectividade em anofelinos oferece várias vantagens. No entanto é necessário que a interpretaçāo dos resultados seja avaliada de forma criteriosa. O fato do teste detectar a proteina circunsporozoita, presente em esporozoitas, e também nos oocistos, pode levar a uma falsa incriminação vetorial. 
Sabe-se que desenvolvimento dos esporozoítas não ocorre de forma sincrônica. Os oocinetos podem ser formados, mas não se desenvolver até o estágio de oocistos, Estes últimos por sua vez podem ser produzidos, porém não gerar esporozoítas em seu interior. Ainda, os esporozoítas formados podem ser incapazes de invadir as glândulas salivares. Na tentativa de minimizar este problema, alguns autores empregam mosquitos cortados transversalmente no tórax, entre o primeiro e o terceiro pares de pernas e a porção anterior, retirando as asas e as pernas Procuram assim, assegurar que a positividade encontrada seja ocasionada por oocistos ou esporozoítas.

Tal procedimento simplesmente minimiza a possibilidade de contaminação, uma vez que, com o rompimento do oocisto maduro os esporozoítas encontrados no seu interior são liberados na hemolinfa, e em seguida, difundem-se para toda a hemocele onde eventualmente concentram-se dentro das glândulas salivares.

Os esporozoítas podem ser encontrados em diferentes regiões do anofelino: por toda a hemolinfa, em oocistos e dentro da glândula salivar. ROBERT et. al (1988) verificaram a positividade do An. gambiae pelo ELISA em diferentes regiões do corpo do inseto, experimentalmente infectado pelo $P$. falciparum. Os pesquisadores realizaram dissecções isolando a cabeça, as glândulas salivares, os túbulos de Malpighi, os tecidos abdominais, o tórax, o estômago, as asas e as pernas dos anofelinos e posteriormente os testaram por ELISA, encontrando positividade em todas as regiões mencionadas.

Trabalhos relacionados com estudos de competência vetorial desenvolvidos em Rondônia, na região de Costa Marques, por KLEIN et. al (1991 a, 1991 b) contribuiram de maneira significativa, apontando as dificuldades na interpretação dos resultados do ELISA e na verificação da infectividade de anofelinos. Os autores realizaram testes de suscetibilidade com várias espécies de anofelinos criados em laboratório e alimentados em pacientes com gametócitos. An darlingi e An. oswaldoi apresentaram poucos esporozoítas nas glândulas salivares e muitos oocistos na parede do 
estômago, enquanto An. deaneorum apresentou alta positividade, mostrando ser mais sujeito à infecção quando comparado ao An. dartingi. Em relação à suscetibilidade à infecção, o An. albitarsis apresentou oocistos de $P$. falciparum, porém não houve invasão das glândulas salivares pelo esporozoitas.

RUBIO-PALIS et. al (1994a) realizaram um estudo extremamente relevante sobre Capacidade Vetorial do An. nuneztovari, An. albitarsis s.I. e An. triannulatus na Venezuela ocidental. Os pesquisadores demonstraram que os parâmetros relativos ao indice de antropofilia, densidade populacional e paridade e antropofilia e paridade contribuíram com mudanças na Capacidade Vetorial dessas espécies. Os resultados apontaram que o declínio na incidência de malária (de 41,1 para 7,5 por mil) no período de um ano deveu-se à diminuição da Capacidade Vetorial das referidas espécies.

As pesquisas acima ilustram a importância do uso de Parámetros Entomológicos para o entendimento da dinâmica de transmissão da malária. Entretanto a presença de heterogeneidade anofélica numa mesma área dificulta o uso dos parâmetros entomológicos rotineiramente avaliados.

A presença de mais de uma espécie agindo como vetor primário e secundário na mesma área geográfica foi verificada por HAYES et. al (1987), HERRERA et. al (1987), LOUNIBOS e CONN (2000). Estes trabalhos ressaltam a necessidade do conhecimento da participação de cada uma das espécies na transmissão da malária.

Um exemplo tipicamente brasileiro diz respeito ao An. darlingi, principal espécie transmissora nas extensas áreas da região amazônica, e sua coexistência com outras espécies anofélicas (ARRUDA et. al 1986; OLIVEIRA-FERREIRA et. al 1990; BRANQUINHO et al 1993; PÓVOA et al 1993, SEGURA 1998; PÓVOA et. al 2001; CONN et. al in press). Anopheles albitarsis s.l., por exemplo, foi considerado um vetor de importância relativa em áreas restritas do Brasil (DEANE 1986). Atualmente a espécie apresenta um papel significativo na transmissão da malária, coexistindo com o vetor 
primário An. darlingi e outros vetores secundários (SEGURA 1998). O mesmo pode ser dito sobre outros anofelinos (BRANQUINHO et. al 1993).

Portanto é de fundamental importância ir além da incriminação vetorial, examinando a complexidade da associação das múltiplas espécies, assim como esclarecer o papel desempenhado pelas espécies cripticas na transmissão da malária. Além disso, é extremamente necessário realizar um mapeamento dos anofelinos em microrregiões, incluindo-se áreas recémdesmatadas, posto que a substituição das espécies anofélicas relaciona-se às mudanças no meio ambiente e a plasticidade genética dos mosquitos em se adaptar a estas mudanças.

Por exemplo, no trabalho que desenvolvemos no Acre observamos que nas coletas realizadas em 1991 houve predomínio de $A n$. oswaldoi (85\%) e An.deaneorum (15\%). Ao voltarmos mesma área em 1994, encontramos: An.albitarsis, An.deaneorum, An. rangeli, An.oswaldoi, An.dartingi, An.strodei e An. evansae. Atribuímos a grande diversidade entre as espécies encontradas no segundo periodo ao fato de a área ter sofrido desmatamento recentemente, o que poderia ter ocasionado uma eventual modificação na fauna devido às interferências humanas no ambiente (BRANQUINHO et. al 1993, 1996).

Nossos resultados concordaram com os dados obtidos por TADEl et. al (1993), mostrando que criadouros situados em áreas alteradas pelo homem apresentaram uma maior variabilidade de espécies de Anopheles. Os autores capturaram somente A.oswaldoi e A.mediopunctatus em criadouros situados em áreas não alteradas.

O número de casos vem aumentando drasticamente no Estado do Amapá nos últimos dez anos provavelmente devido ao aumento da mobilidade populacional desencadeada após a criação da área de livre comércio nos municipios de Macapá e Santana, em 1991. A partir de então, a região passou a ser um novo pólo de migração na Região Amazônica, o que pode estar ocasionando profundas alterações no meio ambiente. Jabe 
às autoridades de saúde do Estado manterem-se em alerta para possiveis mudanças na fauna anofélica e sua associação com os casos de maária.

Nossos resultados apontaram duas espécies importantes na região do rio Matapi, Estado do Amapá: An. darlingi, espécie mais capturada ao longo dos meses que totalizou 19. 424 exemplares, e An.albitarsis, com 5.773 espécimens. Em relação à positividade do An. darlingi e do An. albitarsis observamos que ambas se infectam com as cinco espécies de Plasmodium (vide tabela 18). Sabendo-se que An. albitarsis é considerado vetor secundário na transmissão da malária, o nosso objetivo foi validar ao máximo a positividade de tal espécie. Por esta razão, o limiar de reatividade do ELISA foi eștabelecido pela média das absorbâncias de 100 mosquitos negativos, acrescida de 3 desvios padrão, procurando-se minimizar o aparecimento de resultados falsos positivos.

Em fevereiro de 1999, foi realizada uma coleta na localidade de Bom Jesus de Fernandes, Municipio de Tartarugalzinho. An. braziliensis foi a espécie mais encontrada, totalizando $99 \%$ da coleta $(n=347)$, estando infectado somente pelo Plasmodium vivax like $(0,8 \%)$. Observamos uma diferença marcante entre a localidade acima e São Raimundo do Pirativa. Estes resultados demonstram a importância de conhecer as espécies vetoras e sua densidade no tempo e no espaço.

Durante as nossas capturas, Voorham (comunicação pessoal) procurou anofelinos ao redor dos povoados nas três localidades. Tanto machos quanto fêmeas de An. darlingi foram encontrados pousando em vegetação baixa enquanto An. albitarsis encontraram-se ao redor e embaixo de palafitas. Nenhuma das espécies foi encontrada dentro das casas. A construção das moradias é feita de tal forma que não existam paredes completas para servir de pouso aos insetos. Foram observadas diferenças no comportamento hematofágico entre as duas espécies de arofelinos. Anopheles albitarsis mostrou maior atividade durante as primeiras quatro horas da noite, enquanto An. darlingi permaneceu ativo durante toda noite. Nas Américas observa-se grande diversidade na atividade hematofágica 
entre as espécies de anofelinos e em membros de uma mesma espécie em relação a sua distribuição geográfica e aos diferentes períodos do ano (ZIMMERMAN 1992; VOORHAM, in review).

No trabalho de SEGURA (1998), item 1.6. da Introdução, o autor realizou capturas somente das $19: 00$ às $21: 00$ horas, fato que poderia ter comprometido a constatação da real participação do An. darlingi na cadeia de transmissão da doença. As nossas coletas foram de 12 horas, pois consideramos que fornecem maior precisão quanto às espécies de anofelinos capturadas nas áreas, nas medidas de antropofilia, no índice de esporozoítas e na taxa de sobrevivência dos mosquitos.

Conforme comentado anteriormente, achamos que apenas dados relacionados com a população humana não demonstram o que realmente está acontecendo na área de transmissão de malária. Devemos sempre que for possivel correlacionar os dados soroepidemiológicos com os estudos entomológicos para que não corramos o risco de direcionar nossos estudos e obter dados inconclusivos. Infelizmente não pudemos fazer um estudo entomológico e soroepidemiológico na mesma época, porém os dados obtidos da população, que serão discutidos adiante, poderão auxiliar em futuros estudos destas populações.

Conforme discutido em Mat. e Métodos, sangue de individuos das três localidades foram colhidos e submetidos a exames de gota espessa, detecção de anticorpos contra formas assexuadas (IFI), deteç̧ão de anticorpos contra peptideos relacionados com a região repetitiva da CSP das várias espécies e variantes de plasmódios.

Neste estudo soroepidemiológico, observamos que grande parte dos individuos estudados já haviam tido contato com malária. Esta constatação foi medida por meio do encontro de anticorpos da classe IgG contra as formas sangüineas de $P$. vivax e $P$.falciparum. A porcentagem de individuos com resultados positivos em São Raimundo, São João e Santo Antonı. para P. vivax, foram, respectivamente, $80 \%, 50 \%$ e $70,8 \%$. Porcertagens 
menores foram observadas para deteç̧ão de anticorpos contra $P$.falciparum: $31,4 \%, 28,6 \%$ e $29,1 \%$, respectivamente para as localidades de São Raimundo, São João e Santo Antonio.

Com relação a infecções recentes, isto é, detecção de anticorpos da classe IgM, observamos que houve número igual, de aproximadamente $50 \%$, para ambas as espécies de plasmódios nas três localidades estudadas. Estas reações podem originar em resultados cruzados entre as espécies de plasmódios, porém, raros resultados positivos foram observados para ambos os plasmódios, indicando que talvez a malária por $P$. falciparum esteja aumentando nestas populações.

À primeira vista, surpreendeu-nos o resultado obtido em ELISA, visto que $36,7 \%$ da população total (três localidades) apresentaram anticorpos anti $P$. malariae. Não observamos diferenças estatisticamente significativas entre as absorbâncias obtidas nos soros coletados em São Raimundo e em Santo Antonio. Verificamos diferença com relação à soropositividade de P.malariae $(p<0.05)$ nos soros coletados em São João. Infelizmente não podemos afirmar se esta população está sendo infectada com $P$.malariae devido ao número baixo de amostras coletadas. Porém acreditamos elucidar melhor esta questão nos futuros estudos que faremos nesta população.

Ao analisarmos o número de casos notificados pela FUNASA em todo o Estado do Amapá nos anos de 1995, 1996, 1997 e 1998, verificamos a presença de um único caso dessa espécie nesse período. Sabemos que o encontro de anticorpos em reações sorológicas é um dos meios indiretos de se analisar o contato do individuo com a doença. O ELISA com peptideos sintéticos, correspondentes à porção repetitiva da proteína circunsporozoita, é utilizado como um marcador epidemiológico da doença e permite investigar a possibilidade da população manter contato com anofelinos infectados ou não. Entretanto o resultado positivo não indica que o individuo tenha desenvolvido obrigatoriamente a doença, pois para tanto é preciso que um determinado número de esporozoitos consiga atingir os hepatócitos 
O encontro de anticorpos contra as formas sangüíneas só nos diz que este indivíduo provavelmente contraiu a doença, porém continuamos sem encontrar o parasita. Entretanto estas informações iniciais são de suma importância em uma avaliação epidemiológica. Sendo assim, o encontro do parasita é o único marcador que nos dá a certeza de que os individuos contraíram de fato a doença.

ARRUDA e VOORHAM 1994 (dados não publicados) trabalhando em área de garimpo ao norte do Estado do Mato Grosso demonstraram por meio da análise de lâminas de gota espessa que $30 \%$ dos casos reportados pela FUNASA como $P$. vivax foram causados pelo $P$. malariae. CAVASINI et. al 2000, exploraram esta questão ao compararem resultados obtidos na identificação de Plasmodium por meio da gota espessa, com a técnica de PCR, em 96 pacientes positivos para malária e residentes em Rondônia. Surpreendentemente, por meio de diagnóstico via PCR, 10\% dos pacientes eram positivos para P.malariae. Os autores discutem o problema da subnotificação desta espécie no Brasil e suas implicações no controle da doença.

Provavelmente a ocorrência do $P$. malariae seja sistematicamente sub- notificada devido à:

- Baixa parasitemia nos portadores, visto que os merozoítas desta espécie preferencialmente invadem hemácias maduras (Di SANTI e BOULOS 1999).

- Baixa sensibilidade da gota espessa: em regiōes de transmissão instável é necessária a introdução de metodologias mais sensivess, com limiar de detecção inferior a 100 parasitas/.I de sangue. Uma desvantagem na gota espessa é a perda de parasitas que pode ser de $66 \%$ dos trotozoitas e de $80 \%$ a $90 \%$ de gametócitos. Apesar dessa perda, a gota espessa é cerca de 20 vezes mais sensivel que a extensão de sangue, devido à camada de sangue ser 20 a 30 vezes mais densa. Em contrapartida, no esfregaço o Plasmodium é visualizado dentro das células, preservandu-se a 
morfologia do parasita e possibilitando o estabelecimento de uma relação entre o tamanho da hemácia e o parasita. (ÁVILA, 1994).

- Dificuldade na identificação da espécie: A coloração da gota espessa pelo método de Giemsa produz a hemólise das células sangüineas promovida pela solução de azul de metileno fosfatado, a fim de promover a desglobinização e pré-coloração do material. Esta coloração revela melhor as granulações de Schuffner, de cor avermelhada, nas hemácias com $P$.vivax e $P$.ovale. No $P$. malaniae podem estar presentes as granulações de Ziemann, que são menores que as de Schuffner. A hemácia com P.malariae não é dilatada. Os trofozoítas apresentam-se em forma de banda, atravessando a hemácia. Entretanto esta forma evolutiva nem sempre é encontrada. Os gametócitos são redondos, repletos de pigmento malárico (Di SANTI e BOULOS 1999).

A qualidade da hemoscopia está na dependência de diversos fatores, dentre eles: a preparação dos diferentes métodos de coloração, controle de qualidade dos reagentes, qualidade do equipamento, experiência e dedicação do microscopista. Uma sugestão para minimizar a ineficiência da notificação do $P$. malariae é efetuar além da gota espessa a extensão de sangue (em uma làmina separada), quando surgir casos de P.vivax duvidosos ou em casos de baixa parasitemia. Este procedimento é tido como realizado em diversas regiōes brasileiras, porém observaçöes ao longo dos anos nos mostram que tal prática não é executada.

Em relação ao encontro de anticorpos anti P.vivax VK247 e P vivax like, nossos resultados concordam com os obtidos nos estudos soroepidemiológicos de prevalência da malária desenvolvidos no Estado do Pará, Brasil, situado na fronteira sul do Estado do Amapá. por ARRUDA et. al $(1989,1996)$. ARRUDA et. al (in press) também realizou um importante estudo soroepidemiológico em cinco estados da Amazônia, com o objetivo de verificar a disseminação das variantes de $P$. vivax. Os autores examinaram 1081 amostras de soro, gotas espessas e esfreģว̧os sangüineos da populaçāo nativa. migrantes e garimpeiros residentes. Os 
resultados demostraram a presença das variantes de $P$. vivax nos cinco estados trabalhados. Verificou-se que existe uma variação significante na media geométrica dos títulos de anticorpos anti-esporozoítos nos diferentes estados. Os autores aventam a possibilidade dessa variação na média geométrica dos títulos estar relacionado com o periodo de ocupação da região, estabilidade da população e a diversidade de vetores.

Diante dos resultados obtidos no ELISA com peptídeos sintéticos, ocorreu-nos a indagação a respeito de eventuais reações cruzadas entre as espécies de Plasmodium pesquisadas.

DUARTE em sua tese de Doutorado (comunicação pessoal) vem desenvolvendo uma interessante abordagem epidemiológica em área de influência da Usina Hidrelétrica de Porto Primavera, divisa entre Mato Grosso do Sul e São Paulo. A autora não encontrou reação cruzada nos 216 soros de individuos testados usando os mesmos peptideos que empregamos (0/216). Ao processar soros de 239 macacos da mesma área de estudo, verificou que apenas cinco apresentaram reações cruzadas (2\%).

Em trabalho anterior, DUARTE (1998) estudou 51 soros de macacos capturados na Usina Hidrelétrica da Serra da Mesa, Goiás. A autora encontrou apenas quatro soros que apresentaram reações cruzadas entre $P$. malariae/ P.brasilianum e $P$. vivax VK 247. No mesmo trabalho, examinadose 53 soros de macacos capturados em São Paulo não foram observadas reações cruzadas.

CURADO (1995) fez um relevante estudo sobre as variantes em área de baixa endemicidade em São Paulo. Ao testar soros por ELISA, usando peptideos sintéticos, encontrou $4,3 \%$ para o $P$.vivax, $5,3 \%$ para $F$ vivaxlike, $7,1 \%$ para a variante VK 247 e 3,6\% para o $P$. malariae. Na to:alidade de sua amostragem (439), que abrangeu áreas do Vale do Ribeira, Baixada Santista e Litoral Norte, apenas quatro soros reagiram cruzadamerite com $P$. vivax VK 247 e $P$. malaniae $(0,9 \%)$. 
A autora aventa a possibilidade das variantes relacionarem-se às características da malária desta região que, diagnosticada como malária vivax, acomete os pacientes (residentes na região) com sintomatologia bastante atípica. A parasitemia geralmente é baixa e os casos são geralmente oligossintomáticos ou assintomáticos. A malária presente na Serra do Mar evidencia um quadro peculiar de transmissão que talvez envolva reservatórios simianos, atuando como fonte de transmissão na cadeia epidemiológica (CURADO, 1995; CURADO et. al 1997).

Diferentemente dos resultados obtidos em áreas nāo endémicas, nossos resultados demonstram haver reação cruzada entre os anticorpos anti CSP dos diversos peptideos. Em Sāo Raimundo, observamos que 8,6\% dos soros reagiram tanto para $P$. malaniae, $P$ vivax $e P$. vivax like. Em São Joāo, $21,4 \%$ dos soros reagiram com $P$. malaniae, $P$. vivax e $P$. vivax VK247, enquanto na localidade de Santo Antonio esta porcentagem foi de $12.5 \%$ para P.malariae, P.vivax, $P$.vivax like e $P$.vivax VK247.

A literatura aponta-nos um estudo realizado por COCHRANE et. al 1990 com soros de indios da Região Amazônica. Foi observado que alguns soros positivos para a variante VK247 também reagiram com esporozoitas e com peptideo de P.malanae/P.brasilianum. Feita a absorção, foi observada significativa queda na reatividade dos soros positivos para $P$ vivax VK 247. Anticorpos policlonais e monoclonais de camundongos imunizados com esporozoitas de $P$. brasilianum apresentaram reação cruzada para $P$. vivax VK 247. Estes resultados sugerem que exposições ao $P$ brasilianum ou $P$. malanae podem gerar anticorpos anti-esporozoitas que reagem com $F$ vivax VK247. Não absorvemos os soros positivos para $P$. malariae com $P$. vivax, mas imaginamos que, tal como no trabalho acima, esta porcentagem tende a diminuir.

Nossos resultados mostraram baixa positividade de infecção do P. malanae em An. albitarsis (4/3523) e An. darlingi (4/9450). PÓVOA et al 2001. na Serra do Navio, encontraram elevada positividade do $P$. male rae em anofelinos. Os autores acreditam na manutenção de um ciclo silvestre. 
devido à presença de diversos macacos observados nas circunvizinhanças das áreas trabalhadas. Apesar do encontro elevado de mosquitos positivos com $P$. malariae, os autores não acreditam que esta espécie apresente grande significado epidemiológico devido à ausência de notificação de casos no Hospital local e pela FUNASA.

Finalizando, inúmeros fatores cooperam para o terrivel panorama mundial atribuido à malária nos últimos anos, dentre eles, a falta de conhecimento sobre as interações das espécies vetoras e do agente etiológico com 0 meio ambiente, condições estas, que impedem o estabelecimento de um programa de controle capaz de atuar de forma efetiva nas diversas regiões brasileiras. Esperamos que os resultados obtidos neste trabalho, contribuam com as autoridades locais para a implantação de estratégias de controle mais sistematizadas e dirigidas às populações ribeirinhas, não só do Estado do Amapá, como também das populaçōes da Região Amazônica de modo geral. 


\section{Conclusões}

1. A ocorrencia de malária verificada por meio do teste da gota espessa, apresentou alta positividade para $P$.vivax e $P$.falciparum. A doença acometeu principalmente crianças menores de 15 anos de idade;

2. Devido ao fato de os dados de notificação de malária da áreá obtidos por busca passiva mostrarem casos esporádicos por $P$. falciparum, e nossos resultados pela busca ativa apresentar $50 \%$ desta espécie, aventamos duas hipóteses:

- Possivelmente estes dados refletiram negativamente sobre a precisão da notificação da malária neste Estado.

- Provavelmente a malária por $P$. falciparum esteja aumentando nestas populações;

3. A prevalència total do teste de Imunofluorescência Indireta com antígeno de $P$. falciparum da classe IgG foi $30,1 \%$ e da classe $\lg M$ foi $16,4 \%$. Para $P$.vivax a classe IgG apresentou $71,2 \%$ de positividade enquanto para IgM foi $15,0 \%$;

4. Anticorpos anti-esporozoitas do P.vivax foi o predominante na região $(38,4 \%)$, seguido do $P$. malariae $(36,7 \%)$, $P$. falciparum $(26,0 \%)$, P.vivax VK $247(20,5 \%)$ e $P$. vivax like $(17,8 \%)$;

5. Devido à alta prevalência de anticopos anti-CSP de $P$.malariae e a presença de vetores positivos para esta espécie, sugerimos que a notificação do $P$. malariae seja sistematicamente sub- notificada nesta região;

6. A presença do An. albitarsis foi mais pronunciada na época de chuva enquanto que An. darlingi no periodo de seca. Estes resultados merecem estudos posteriores. 
7. An. darlingi e An. albitarsis são suscetiveis a infecção pelo P.falciparum, P.vivax, P.vivax VK247, P. vivax like e P.malariae; 


\section{Referências Bibliográficas}

[Anonymus] Amabusca. [on line]. [snt] Disponivel em

URL:http:www.amapabusca.com.br [2001 mar 5]

[Anonymus] Amapage. [on line]. Disponivel em

URL:http://www.Brasil.terravista.pt/claridade/3316. [ [ [ 2000 dez 30$]$ [2001 fev 2] [2001 mar 3].

Andrade L de, Martelli CM, Oliveira RM, Arias JR, Zicker F, Pang L. High prevalence of asymptomatic malaria in gold mining areas in Brazil. Clin Infect Dis 1995; 20: 475.

Antuñano FL. Situação dos programas de erradicação da malária nas Américas. XX informe. Supl. Rev Brasil. Malariol. D. Trop.1985; 37:31-7.

Amot DE, Barnwell J W, Tam JP, Nussenzweig V, Nussenzweig RS. Circumsporozoite protein of $P$. vivax gene cloning and characterization of the immunodominant epitope. Science 1985; 30: 815-8.

Arruda ME, Aragaki C, Gagliardi F, Haile RW. A seroprevalence and descriptive epidemiological study of malaria among Indian tribes of the Amazon basin of Brazil. Ann Trop Med Parasitol 1996; 90:135-143.

Arruda ME, Carvalho MB, Nussenzweig RS, Maracic M, Ferreira AW, Cochrane $\mathrm{AH}$. Potential vectors of malaria and their different susceptibility to $P$. falciparum and $P$. vivax in northern Brazil identified by immunoassay. Amer J Trop Med Hyg 1986; 35 (5): 873- 881.

Arruda ME, Dutra L, Martins J, Zimmerman RH. in review. Widespread distribution of $P$. vivax variants VK247 and vivax-like human malaria in the Amazon region of Brazil.

Arruda ME, Nardin EH, Nussenzweig RS, Cochrane AH. Sero epidemiological studies of malaria in Indian tribes and monkeys of the Amazon basin of Brazil. Amer J Trop Med Hyg 1989; 41 (4): 379-385 Arruda ME, Souza RC, Veiga ME, Ferreira AF, Zimmerman RH. Prevalence of $P$. vivax variants VK247 and $P$. vivax-like human 
malaria: a retrospective study in Indian populations of the Amazon region of Brazil. Trans Roy Soc Trop Med Hyg 1998, 92: 628.

Ávila SLM. Avaliação do desempenho de métodos de laboratório no diagnóstico da malária humana; sugestões para normatização. São Paulo; 1994. [Tese de doutorado - Instituto de Ciências Bomédicas da USP].

Barr PJ, Gibson HL, Enea V, Arnot DE, Hollingdale R, Nussenzweig V Expression in yeast of a $\mathrm{P}$. vivax antigen of potential use in human malaria vaccine. J. Exp. Med 1987; 165: 1160-71.

Beier JC, Oster CN, Onyango FK, Bales JD, Sherwood JA, Perkins PV, Chumo DK, Koech DV, Whitmire RE, Roberts CR, Diggs CL, Hoffman $\mathrm{SL}$. Plasmodium falciparum incidence relative to entomologic inoculation rates at a site proposed for testing malaria vaccines in western Kenya. Amer J Trop Med Hyg 1994; 50: 529-536.

Bhatt RM, Sharma RC, Kohli VK, Gautam AS, Gupta DK. Biting rhythms of malaria vector An. culicifacies in Kheda district, Gujarat. Indian $\mathbf{J}$ Malariol 1991; 28: 91-97.

Birley $\mathrm{MH}$, Chartwood JD. The effect of moonlight and other factors on the oviposition cycle of malaria vectors in Madang, Papua New Guinea. Ann Trop Med Parasitol 1989; 83: 415-22.

Bouma MJ, Dye C. Cycles of malaria associated with El Nino in Venezuela. JAMA 1997; 278 (21): 1772-4.

Branquinho MS, Araujo MS, Natal D, Marreli MT, Rocha RM, Taveira FA, Klotzel J. Anopheles oswaldoi a potential malaria vector in Acre, Brazil. Trans Roy Soc Trop Med Hyg 1996; 90: 233.

Branquinho MS, Lagos CB, Rocha RM, Natal D, Barata JM, Cochrane $\mathrm{AH}, \mathrm{Nardin} \mathrm{E}$, Nussenzweig RS, Kloetzel J. Anophelines in the state of Acre, Brazil, infected with $P$. falciparum, $P$. vivax, the variant $P$. vivax VK247 and P. malariae. Trans Roy Soc Trop Med Hyg 1993; 87: 391 394.

Branquinho MS, Marrelli MT, Curado I, Natal D, Barata JMS, Tubaki R, Carreri-Bruno GC, Menezes RT \& Kloetzel J. Infecção dn An. 
(Kerteszia) cruzii por $P$. vivax e $P$. vivax variante VK247 nos Municípios de São Vicente e Juquitiba, São Paulo. Pan. Am. J. Public Health 1997; 2(3): 189-193.

Branquinho MS. Estudo dos potenciais vetores de malária no Acre,

Brasil. Rev. Inst. Med. trop. Săo Paulo 1997. 39 (1): 61-63.

Bruce-Chwatt LJ. Essential Malariology, $2^{\text {rd }}$. London: William Heinemann Medical Books.Ltd; 1985.

Bruce-Chwatt LJ. Man against malaria, conquest or defeat. Trans. R. Soc. Trop. Med. Hyg. 1979; 73: 605-17.

Burkot TR, Graves PM. The value of vector-based estimates of malaria transmission. Ann Trop Med Parasitol 1995; 89:125-134.

Butker D, Maurice J, O'Brien C. Time to put malaria control on the global agenda. Nature 1997; 386: 535-536.

Camargo EP, Alves F, Pereira da Silva L. Symptomless P. vivax infections in native Amazonians. The Lancet 1999; 353:9162.

Camargo LM, Ferreira UM, Krieger H, Camargo EP, Pereira da Silva LH. Unstable hypoendemic malaria in Rondônia (Western Amazon Region, Brazil): Epidemic outbreaks and work-associated incidence in an agroindustrial rural settlement. Amer Journal of Trop Med and Hyg 1994; 51: $16-26$.

Camargo LM, Noronha E, Salcedo JM, Dutra AP, Krieger H, Pereira da Silva LH, Camargo EP. The epidemiology of malaria in Rondonia (Western Amazon region Brazil): study of a riverine population. Acta Trop Jan 15 1999; 72 (1): 1-11.

Capibaribe J. A saúde no Amapá. [on line]. Disponivel em http://www.uol.com.br/saude.ap.gov.br/. [2001 abr 11]

Castilla RE, Sawyer D. Malaria rates and fate: a socioeconomic study of malaria in Brazil. Soc. Sci. Med 1993; 37:1137-1145.

Cavasini MTV, Ribeiro WL, Kawamoto F, Ferreira MU. How prevalent is P. malariae in Rondônia, Western Brazilian Amazon. Rev. Soc. Bras. Med. Trop 2000; 33 (5): 489-492. 
Cerqueira NL. Distribuição geográfica dos mosquitos da Amazônia. Revista Brasileira de Entomologia 1961; 10:111-168.

Chartwood JD, Paru R, Dagoro $H$. Lagog Influence of moonlight and gonotrophic age on biting activity of An. farauti (Diptera: Culicidae) from Papua New Guinea. J. Med Entomol 1986; 23: 132-135.

Cochrane AH, Collins WE, Nussenzweig RS. Monoclonal antibody identifies circumsporozoite protein of $P$. malariae and detects a common epitope on $P$. brasilianum sporozoites. Infec. Immun 1992; 45: $592-5$.

Cochrane AH, Nardin EH, Arruda M, Maracic M, Clavijo P, Collins WE, Nussenzweig RS. Widespread reactivity of human sera with a variant repeat of the circumsporozoite protein of $P$. vivax. Am. J. Trop.Med. Hyg 1990; 43: 446-5.

Colauto EM, Barraviera B, Meira DA, Matsubara LS, Pellegrino J, Machado PE, Sogayar R ,Barboza AF, Silva EA, Colauto R, Pirolla JÁ, Mendes RP. Malaria in the municipality of Humaitá, State of Amazonas. XII. Incidence of erythrocyte resistance factors in the general population and in patients: hemoglobin $S$ and Duffy blood system.Ver. Instit. Med. Trop. São Paulo 1981; 23 (Suppl. 5): 72-78.

Collins FH, Besansky NJ. Vector Biology and the Control of Malaria in Africa. Science, 1994; 264: 1874-1875.

Consoli RA, Oliveira RL. Classificação e Principais Espécies de importância Sanitária In: Principais Mosquitos de Importância sanitária no Brasil. Rio de Janeiro, FIOCRUZ :17-92; 1994.

Constantine C. Li SL, Torre AD, Sagnon NF, Coluzzi M, Talor CE. Density, survival and dispersal of An. gambiae complex mosquitoes in a West African Sudan savanna village. Med Vet Entomol 1996; 10 : 203-219.

Curado I, Duarte AMR, Lal AA, Oliveira SG, Kloetzel JK. Antibodies antibloodstream and circumsporozoite antigens $(P$. vivax and $P$. malariae/P.brasilianum) in areas of very low malaria endemicity in Brazil. Mem. Inst. Oswaldo Cruz 1997; 92: 235-43. 
Curado I. Soroepidemiologia de malária em áreas de baixa endemicidade no Estado de São Paulo. São Paulo; 1995. [Dissertação de Mestrado - Instituto de Ciências Biomédicas da Universidade de São Paulo].

David ZG. Moustiques Anthropophiles de la Vilee D'Abidjan. Faculté des Sciences et Techiques de L'université Nationale de CoteD'ivoire (Abdijan); 1991. [Tese de Doutorado]

Deane LM, Causey OR, Deane MP. Notas sobre a distribuição e a biologia dos anofelinos das regiões nordestina e amazônica do Brasil. Rev. Ser. Esp. Saúde Pub 1948; 4: 827-965.

Deane LM. A cronologia da descoberta dos transmissores da malária na Amazônia Brasileira. Mem. Inst. Oswaldo Cruz, 1989; 84 (Suppl IV): 149-156.

Deane LM. Malaria vectors in Brazil. Mem Inst Oswaldo Cruz 1986; 81 (suppl. II): 5-14.Deane LM. Malaria studies and control in Brazil. Am. J. Trop. Med. Hyg 1988; 38: 223-30.

Deane LM. Os grandes marcos na história do controle da malária. Revista da Sociedade Brasileira de Medicina Tropical 1992; 25: $12-$ 22.

Di Santi SM, Boulos M. Protozoários-Malária In: Cimmerman B, Cimmerman S. Parasitologia Humana e seus fundamentos. $1^{\mathrm{a}} \mathrm{ed}$. São Paulo: ed. Atheneu; 1999. p.139-156.

Donald G, McNeil Jr. Preços dos medicamentos em alta em paises africanos The New York Times. Nova lorque, 2000 jun 17.

Duarte AMCD. Estudo de Malária em Macacos Silvestres Brasileiros. São Paulo, 1998 . [Dissertação de Mestrado - Instituto de Ciências Biomédicas da USP].

Dutra AP. Informações sobre Malária. [on line]. snt. Disponivel em URL:http://www. sucen. gov. br [2001 out 30].

Elissa N, Karch S, Bureau P, Ollomo B, Lawoko M, Yangari BE, Georges J. Malaria Transmission in Region of Savanna-forest Mosaic, Haut- 
Ogoouê, Gabon. Journal of the American Mosquito Control Association 1999; 15(1): 15-23.

Faran ME, Linthicum KJA. Handbook of the Amazonian species of An. (Nyssorhynchus) (Diptera: Culicidae). Mosquito System 1981; 13 : 181

Ferreira AW, Sanches MCA. Malária humana: padronização e optimização de testes sorológicos para diagnóstico individual e inquéritos soroepidemiológicos. Rev. Inst. Med. Trop. 1988; 30: 13746.

Fontenille D, Lepers JP, Coluzzi M, Campbell GH, Rakotoarivony I, Coulanges $P$. Malaria transmission and vector biology on Sainte Marie Island, Madagascar. J Med Entomol 1992; 29: 197-202.

Forattini OP, Gomes AC, Natal D, Kakitani I, Marucci D. Preferências alimentares de mosquitos Culicidae no Vale do Ribeira, São Paulo, Brasil. Rev.Saúde Publ 1987; 21:171-187.

Forattini OP, Kakitani I, Massad E, Marucci D. Studies on mosquitoes (Diptera: Culicidae) and anthropic environment. Breeding of An. albitarsis in flooded rice fields in South-Eastern Bazil. Rev. Saúde Pública 1994; 28:329-31.

Fundação IBGE. Contagem da População Brasileira- 1996. Rio de Janeiro; 1997. v. 1 e 2.

Fundação IBGE. Dados demográficos. Rio de Janeiro; 2000.

Fundação Nacional da Saúde. Boletim epidemiógico parcial de malária referentes a 1999. [Informe técnico, Gerência Técnica de Malária; 1999]. Ministério da Saúde. Brasilia, Ano 1:4; 1999.

Fundação Nacional da Saúde. Departamento de Operaçōes, Coordenação de Controle de Doenças Transmitidas por vetores. Controle de Malária: Diretrizes Técnicas. Brasilia: Ministério da Saúde; 1995

Fundação Nacional da Saúde. Ministério da Saúde/ FUNASA -CENEPI, SES/ SINAN. Brasilia, 2001. 
Fundação Nacional da Saúde. Plano de Intensificação das Ações de Controle da Malária na Amazónia Legal; 2000 (Ministério da Saúde/ FUNASA).

Garrett-Jones C. Prognosis for the interpretation of malaria transmission through assessment of the mosquito's vectorial capacity. Nature 1964; 204: 1173-1175

Gonzalez-Ceron L, Rodriguez MH, Nettel JC, Villarreal C, Kain KC, Hernandez JE. Differential susceptibilities of An. albimanus and An. pseudopunctipennis to infections with coindigenous $P$. vivax variants VK210 and VK247 in southern Mexico. Infect immunity 1999; 67: 410-412.

Governo do Estado do Amapá. Subsídios para o zoneamento econômico- ecológico do Amapá. Uma análise das Unidades de Conservação Biológica. Série Técnica Macapá, AP, Julho; 1993

Governo do Estado do Amapá. Instituto de Pesquisas Cientificas e Tecnológicas do Amapá, Programa de Zoneamento Ecológico Económico-Zee; 1996. (IEPA).

Governo do Estado do Amapá. Números de caso das doenças de notificação compulsória por trimestre e coeficiente de incidência. Amapá; 1999. [Secretaria da Saúde/UVE/DE/CVS/SESA-AP].

Governo do Estado do Amapá. [on line] Disponivel em < URL: http://www amapa.gov.br/biodiversidade/principal.htm) $>$ [2000 dez 3]. Governo do Estado do Amapá. [on line]. Disponivel em < URL:http://www. Amapá.história.htm $>$ [2001 fev 2].

Governo do Estado do Amapá. [on line]. Disponivel em < URL:http://www. Mre.gov.br/> [2001 mar 15].

Governo do Estado do Amapá. [on line]. Disponivel em < URL: http://www. economia.gov.br/> [2001 mar 6].

Governo do Estado do Amapá. [on line]. Disponivel em < URL:http:// http://www amapa.gov.br/amapa21.htm> [2001 mar 03] Governo do Estado do Amapá. [on line]. Disponivel em < URL:http://www.ap.gov.br/acoeseprojetos/pdsa.html> [2001 mar 26]. 
Greenwood BM \& Armstrong JRM. Comparison of two simple methods for determination malaria parasite density. Trans. R. Soc. Trop. Med. Hyg 1991; 85:186-8.

Guimarães JH. Systematic Database of Diptera of the Americas South of the United States (Family Culicidae). São Paulo; 1997. Plêiade/Fapesp, 286p.

Hay SI, Rogers DJ, Toomer JF, Snow RW. Annual $P$. falciparum entomological inoculation rates (EIR) across Africa: literature survey, internet access and review. Trans. R. Soc. Trop. Med. Hyg 2000; 94 : 13-127.

Hayes J, Calderón G, Falcón R, Zambrano V. Newly incremented anopheline vectors of human malaria parasites in Junin department, Peru. J Amer Mosq Control Assoc 1987; 33: 418-422.

Herrera S, Suarez MF Sanchez GI, Quinones ML, Herrera M.. Uso de la tecnica inmuno-radiometrica (IRMA) em Anophelinos. de Colombia para la identificacion de esporozoitos de Plamodium. Col Med 1987; 18: $2-6$.

Kain KC, Keytone J, Franke ED, Lanar DE. Global distribuition of a variant of the circumporozoite gene of $P$. vivax. The Journal of Infectious Diseases 1991; 164: 208-210.

Kain KC, Brown AE, Webster HK, Wirtz RA, Keystone JS, Rodriguez MH, Kinahan J, Rowland M, Lanar DE. Circumsporozoite genotyping of global isolates of $P$. vivax from dried blood specimens. J Clin Microbiol 1992; 30:1863-1866.

Klein TA, Lima JBP, Tang AJ. Biting behavior of An. mosquitoes in Costa Marques, Rondonia, Brazil. Rev. Soc. Bras. Med. Trop 1991; 24: 1320.

Klein TA, Lima JBP. Seasonal distribution and biting patterns of Anopheles. mosquitoes in Costa Marques, Rondonia, Brazil. J. Am. Mosq. Cont. Assoc. 1990; 6: 700-7. 
Klein TA, Lima JBP, Tada MS. Comparative susceptibility of Anopheline mosquitoes to P. falciparum in Rondonia, Brazil. Am. J. Trop. Med. Hyg 1991a; 44: 598-603.

Klein TA, Tada MS, Lima JBP. Comparative susceptibility of Anopheline mosquitoes in Rondonia, Brazil to infection by $P$. vivax. Am. J. Trop. Med. Hyg 1991b; 45: 463-70.

Knell AJ. Malária. Oxford Univ.Press; 1991

Kremsner PG, Neifer S, Zotter GM, Bienzle U, Rocha RM, Maracic M, Clavijo P, Nussenzweig RS, Cochrane A H. Prevalence and level of antibodies to the circumsporozoite proteins of human malaria parasites including a variant of $P$. vivax, in the population of two epidemiologically distinct areas in the state of Acre, Brazil. Trans. Roy. Soc. Trop. Med. Hyg 1992; 86: 23-7.

Lal A, De La Cruz VF, Collins WE, Campell GH, Procell PM, McCutchan TF. Circumsporozoite protein gene from $P$. brasilianum. Animal reservoirs for human malaria parasites? J.Biol. Chem 1998a; 263:5495-98

Lindblade KA, Walker ED, Onapa AW, Katungu J, Wilson ML. Highland malaria in Uganda: prospective analysis of epidemic associated with $\mathrm{EI}$ Niño. Trans Roy Soc Trop Med Hyg 1999; 93: 480-487.

Lounibos LP, Conn JE. Malaria vector heterogeneity in South America. Amer Entomol 2000; 46: 238-249.

Lourenço- de- Oliveira R, Guimarães AG, Arlé M, Silva TF, Castro MG, Motta MA, Deane LM. Anopheline species, some of their habits and relation to malaria in endemic areas of Rondonia state, Amazon region of Brasil. Mem. Inst. Oswaldo Cruz 1989; 84: 501-514.

Loyola EG, Gonzalez CL, Rodriguez MH, Arredondo Jimenez JI, Bennett S, Bown DN. An. albimanus (Diptera: Culicidae) host selection patterns in three ecological areas of the coastal plains of Chiapas, southern Mexico. J. Med. Entomol 1993; 30: 518-523.

Macdonald G. The epidemiology and control of malaria.Oxford Press, 1957 
Machado Filho MR. Estudo epidemiológico da malária urbana de Porto Velho- Rondonia, no periodo de julho de 1992 a junho de 1997. [Dissertação de Mestrado - Faculdade de Saúde Pública da USP]; 1999.

Machado RLD, Póvoa MM. Distribution of $P$. vivax variants (VK210, VK247 and $P$. vivax-like) in three endemic areas of the Amazon region of Brazil and their correlation with chloroquine treatment. Trans. R. Soc. Trop. Med. Hyg 2000; 94: 377-81.

Machado RLD. Distribuição das variantes de P. vivax (VK210, VK247 e $P$. vivax-like) em três áreas endêmcias da Região Amazónica Brasileira, utilizando a amplificação do gene codificador da proteina que circunda o esporozoito (CSP). [Dissertação de Mestrado - UFPA]; 1997.

Marques AC. Situação da malária no Brasil, Relatório da Gerência Técnica de Malária, (Fundação Nacional da Saúde). Brasília; 1980.

Marques AC. Migrations and the dissemination of malaria in Brazil. Mem. Inst. Oswaldo Cruz 1986; 81: 17-30.

Marques AC. Human migration and the spread of malaria in Brazil. Parasitology Today 1987; 3: 166-70.

Marques AC. Situação atual do controle da malária no Brasil, Relatório da Gerência Técnica de Malária. [Fundação Nacional da Saúde]. Brasilia; 1993.

Marques AC, Gutierrez HC. Combate à malária no Brasil: evolução situação atual e perspectivas. Rev. Soc. Bras. Med. Trop 1994; 27 : 91-108.

Marrelli MT, Branquinho MS, Lagos CB, Natal D, Kloetzel J. Correlation between positive serology for $P$. vivax., like/P. simiovale malaria parasite in the human and anopheline populations in the State of Acre,

Brazil. Trans. Roy. Soc. Trop. Med. Hyg 1998; 92: 149-151.

Martins E, Capobianco JP, Xavier R, Ventura Z. In: Amapá: um norte para o Brasil organizador Nilson Moulin. São Paulo: ed. Cortez; 2000. 
McGrevy P, Dietze R, Prata AE, Hembree SC. Effects of immigration on the prevalence of malaria in rural areas of the Amazon Basin of Brazil. Mem. Inst. Oswaldo Cruz 1989; 84: 485-91.

Mendis C, Herath PR, Rajakaruna J, Weerasinghe S, Gamage-Mendis $\mathrm{AC}$, Mendis KN, De Zoysa AP. Method to estimate relative transmission efficiencies of Anopheles. species (Diptera: Culicidae) in human malaria transmission. J. Med. Entomol 1992; 29: 188-196.

Ministério da Saúde. Informe epidemiólogico da SUS/CENEPI. 1(17), Brasil; 1992.

Ministério da Saúde - Fundação Nacional da Saúde. Casos de malária no Brasil. DATASUS [on line], 2000

Molineaux L. Entomological parameters in the epidemiology and control of vector-borne diseases. In: Medical Entomology Centenary. Sym Proc Roy Soc Trop Med Hyg 100-105,1978.

Nardin EH, Nussenzweig RS, Nussenzweig V, Harinasuta KT, Collins WE, Tapchaisri $P$, Chomcharn $Y$. Circumsporozoite (CS) proteins of human malaria parasites $P$. falciparum and $P$. vivax. J. Exp. Med. $1982 ; 156: 20$.

Noguer A, Wernsdorfer WH, Kouznetsov R, Hempel J. The malaria situation en 1976. WHO Chron 1978; 32:9-17.

Nussenzweig V, Nussenzweig RS. Circumsporozoite proteins of malaria parasites. Cell 1985; 42:401.

Oliveira-Ferreira J de, Oliveira RL de, Teva A, Deane LM, Ribeiro CDT. Natural malaria infections in anophelines in Rondonia state, Brazilian Amazon. Amer J. Trop. Med. Hyg. 1990; 43: 6-10.

Oliveira DA, Holloway BP, Durigon E L, Collins WE, Lal AA. Polymerase chain reaction and a liquid-phase, nonisotopic hybridization for species-specif and sensitive detection of malaria infection. Am.J.Trop. Med. Hyg. 1995; 52: 139-44.

Ozaki LS, Gwadz RW, Godson GN. Simple centrifugation method for rapid separation of sporozoites from mosquitoes. J. Parasitol.1984; 70: $831-3$ 
Panamerican Health Organization. Status of malaria in the Americas. PAHO/HCP/HCT/98; 1998. (PAHO)

Passos AD, Fialho RR. Malária: aspectos epidemiológicos e de controle. Rev. Soc. Bras. Med. Trop. 1998; 31 (suppl. 2): 93-105.

Phillipson JD. New drugs from nature - It could be new. Phytotherapy Research, 1999; 13: 2-8.

Póvoa MM, Segura N, Lacerda R, Silva OV da, Almeida RN, Lesse R, Rosário V, Milesma WDC. Anophelines infected with human $P$. in the Serra do Navio region of Amapá State, Brazil. Trans Roy Soc Trop Med Hyg 1993; 87:381.

Qari SH, Goldman TF, Povoa MM, Di Santi S, Alpers MP, Lal A. Polymorphism in the circumsporozoite protein of the human malaria parasite P. vivax. Mol. Bioch. Parasitol. 1992; 55: 105-14.

Qari SH, Shi Y, Goldman TF, Udhayakumar V, Alpers MP, Collins E, Lal A. Identification of $P$. vivax like human malaria parasite. The Lancet 1993; 341: 780-3.

Rey L. Os Plasmódios e a Malária: I. Malária . Parasitologia. $1^{\text {a ed. Rio }}$ de Janeiro: Guanabara Koogan; 1991. p.286-97.

Rocha J e Mascarenhas B. M. Observaçōes sobre a atividade diária de mosquitos (Díptera: Culicidae) nos arredores de Belém, Pará, Brasil. Boletim do Museu Paraense Emílio Goeldi, série Zoologia 1994; 10(2): 225-233.

Rocha JAM. Os mosquitos (Diptera: Culicidae) da estação Cientifica Ferreira Penns- ECFPn, Caxiunã, Melgaço, Pará, Brasil: Ataque, Sazonalidade e Estatificação Arbórea. [Dissertação de Mestrado Universidade Federal do Pará \& Museu Emílio Goeldi] Belém; 1996.

Rodriguez MH, Bown DN, Arredondo-Jimenez JI, Villarreal C, Loyola EG, Frederickson CE. Gonotrophic cycle and survivorship of An. albimanus (Diptera: Culicidae) in southem Mexico. J. Med. Entomol 1992; 29 : 395-399.

Rodriguez MH, Gonzalez-Ceron L, Hernandez JE, Nettel JA, Villarreal C, Kain KC, Wirtz RA. Different prevalences of $P$. vivax phenotypes 
VK210 and VK247 associated with the distribution of An. albimanus and An. pseudopunctipennis in Mexico. Am J. Trop. Med. Hyg.2000; 62: $122-7$.

Rosa-Freitas MG, Deane LM, Momen H. A morphological, isoenzymatic and behavioral study of tem populations of An. (Nyssorhynchus) albitarsis Lynch-Arribalzaga, 1878 (Diptera: Culicidae) including from the type-locality-Baradero, Argentina. Mem Inst Oswaldo Cruz 1990; 85:275-89.

Rosa-Freitas MG, Oliveira RL de, Carvalho-Pinto CJ de, Flores-Mendoza C, Fernandes TSN. Anopheline species complexes in Brazil. Current knowledge of those related to malaria transmission. Mem. Inst. Oswaldo Cruz 1998; 93: 651-655.

Rosenberg R, Wirtz RA, Lanar DE, Sattabongkot J, Hall T, Waters AP, Prasittisuk C. Circumsporozoite protein heterogeneity in the human malaria parasite $P$. vivax. Science $1989 ; 245: 973-6$.

Rotraut AGBC, Oliveira RL. Principais Mosquitos de Importância Sanitária no Brasil. FIOCRUZ 1994; 228.

Rubio-Palis Y, Curtis CF, Gonzáles C, Wirtz R A. Host choice of anopheline mosquitoes in a malaria endemic area of western Venezuela. Med. Vet. Entomol 1994b; 8: 275-280.

Rubio-Palis $Y$, Curtis CF. Biting and resting behaviour of anophelines in western Venezuela and implications for control of malaria transmission. Med. Vet. Entomol 1992b; 6: 325-334.

Rubio-Palis $\mathrm{Y}$, Wirtz RA, Curtis CF. Malaria entomological inoculation rates in western Venezuela. Acta Trop 1992c; 52: 167-174.

Rubio-Palis $Y$. Influence of moonlight on light trap catches of the malaria vector An. nuneztovan in Venezuela. J. Ame. Mosq. Control .Assoc. 1992a; 8: 178-180.

Rubio-Palis $Y$. Variation of the vectorial capacity of some anophelines in western Venezuela. Am J. Trop. Med. Hyg. 1994a; 50:420-244.

Salcedo JMV, Camargo EP, Krieger H, Pereira da Siva LH, Camargo LM. Malaria Control in an Agro-Industrial Stettlement of Rondonia 
(Western Amazon Region, Brazil). Mem. Inst. Oswaldo Cruz Mar./Apr.2000; Rio de Janeiro. v.95:2

Santos FR. In: História do Amapá. Quarta edição, Macapá-AP/ Ed.Valcan, 1998.

Santos RlaC. Medida da Capacidade Vetorial de An. albitarsis e de An. (Kerteszia) no Vale do Ribeira, São Paulo, [Tese de Doutorado Faculdade de Saúde Pública da USP]; 2001.

Sawyer D. Economic and social consequences of malaria in new colonization projects in Brazil. Soc Sci Med 1993;37: 1131-1136.

Sawyer D. In: Fronteir malaria in the Amazon Region of Brazil: types of malaria situations and some implications for control. (mimiografado), Brasilia, 1988.

Sawyer D. Malaria on the Amazon fronteir: economic and social aspects of transmission and control. CEDEPLAR/NFMG. Belo Horizonte, Relatório de pesquisa, Belo Horizonte; 1987.

Sawyer D. The potential contribution of social research to control of malaria in Brazil. Mem. Inst. Oswaldo Cruz 1986; 81: 31-7.

Segura MNO. Estudo do An. (Nys) darlingi Root, 1926 e An. (Nys) albitarsis Arribalzága, 1878 (Diptera: Culicidae) como vetores de malária numa mesma área de transmissão, e caracterização de espécies do complexo albitarsis. Belém; 1998. [Dissertação de mestrado - UFPA]

Service M. W. Mosquito Ecology: Field Sampling Methods, 2nd ed. Elsevier Appl Sci Pub 1993. [snt]. London.

Snounou G, Pinheiro L, Gonçalves A, Fonseca L, Dias F, Brown KN, Rosário VE. The importance of sensitive detection of malaria parasites in the human and insect hosts in epidemiological studies as shown by the analysis of field samples from Guinea Bissau. Trans. R. Soc. Trop. Med. Hyg. 1993; 87: 649-53.

Souza C. Malária no Brasil: necessidade em ciência e tecnologia. Rev. Brasil. Malariol. D.Trop 1985; 37: 157-64. 
Spielman A, Kitron U, Pollack RJ. Time limitation and the role of research in the worldwide attempt to eradicate malaria. J. Med. Entomol 1993; 30: 6-19.

Sucupira IMC, Lacerada RL, Galiza D, Lessa RT, Santa Rosa E, Póvoa MM, Segura MN. Entomofauna e taxa de mosquitos anofelinos do município de São Caetano de Odiveiras/ Pará, no periodo de janeiro de 1998 a setembro de 2000. Jirnal Brasileiro. Jornal Brasileiro de Patologia 2001; 37(suppl n4) [XV Congresso Latino Americano de Parsitologia].

SUDAM. Atlas Climatológico da Amazônia Brasileira. Ministério do Interior, Belém, Projeto de hidrografia e climatologia da Amazônia.Belém; 1984 [snt].

Tadei WP, Costa WLS; Correia JM. Estratificação de populações de Anopheles para preferências alimentares. Ciên. e Cult. 1986; 38: 891.

Tadei WP, Mendes dos Santos JM, Scarpassa VM, Rodrigues IB. Incidência, distribuição e aspectos ecológicos de espécies de $A n$. (Diptera: Culicidae), em regiōes naturais e sob impacto ambiental da Amazônia brasileira. In: Ferreira EGM, Leão ELM e Oliveira LA., editores. Bases científicas para estratégias de preservação e desenvolvimento da Amazônia. Instituto Nacional de Pesquisa da Amazônia, Manaus; 1993. v.2.

Tadei WP. \& Santos JBMF. Comportamento de populações de Anopheles na hematofagia. Ciên. e Cult. 1987; 39: 735

Tadei WP, Dutary TB. , Santos JMM, Scarpassa VM, Rodrigues IB, Rafael MS. Ecologic observations on anopheline vectors of malaria in the Brazilian Amazon. Am. Trop. Med. Hyg. 1998; 59: 325-335.

Tadei WP. Biologia de anofelinos amozônicos. XI. Estudos em populações de Anopheles e controle da malária em Ariquemes (Rondônia). Acta Amazonica 1987a; 16/17(único): 151-167.

Tadei WP. Santos JMM, Costa WLS \& Scarpassa VM. Biologia de anofelinos amazônicos. XII. Ocorrência de espécies de Anopheles na dinâmica da transmissão e controle da malária na zona urbana de 
Ariquemes (Rondônia). Rev. Inst. Med. Trop. Săo Paulo 1988; 30:221-251.

Tassanakajon A, Boosaeng V, Wilainat P, Panyim S. Polymerase chain reaction detection of $P$. falciparum in mosquitoes. Trans. Roy.Soc. Trop. Med. Hyg 1993; 87: 273-5.

Tauil PL. Comments on the epidemiology and control of malaria in Brazil. Mem. Inst. Oswaldo Cruz 1986; 81: 39-41.

Tauil PL. Malária: Agrava-se o quadro da doença no Brasil. Ciência Hoje $1984 ; .2: 58-64$.

Tubaki RM. Biting activity of An. (Kerteszia) cruzii (Culicidae) in domiciliar habitats in the Southern Atlantic Forest Peruibe of São Paulo, Brasil, Rev.Bras Entomol. 1993; 37: 559-575.

Venkatachalam U, Qari S, Patterson P, Collins W Lal. Monoclonal antibodies to the circumsporozoite protein repeats of a $P$. vivax-Like human malaria parasite and $P$. simiovale. Infection and Immunity 1994; 62: 2098-2100.

Voorham $\mathrm{J}$, (in review). Intra-populacional plasticity in the biting activity patterns of Anopheles darlingi (Diptera: Culicidae) in Amapá State, Brazil.

Voorham J. Os $\mathrm{N}$ van, Kaay $\mathrm{HJ}$ van der. Reappearance of $P$. malariae in Suriname? Trans Roy Soc Trop Med Hyg, 87: 243-244, 1993.

Wernsdorfer WH. General Introduction: TDR activities im malaria research In: Maurice J, Pearcr AM. (Ed.) Tropical Disease Research a global partnership 1987; Geneva: Atar. c.2:.22-4.

Wernsdorfer WH. The importance of malaria in the world. In: Kreier JP. Malaria. London: Academic Press.; 1980. p 1-93. v. 2

Wilkerson RC, Parsons TJ, Klein TA, Gaffigan TV, Bergo E, Consolim J. Diagnosis by random amplified polymorphic DNA polymerase chain reaction of four cryptic species related to An. (Nyssorhynchus) albitarsis (Diptera: Culicidae) from Paraguay, Argentina, and Brazil. J Med Entomol 1995; 2: 697-704. 
Wirtz RA, Burkot TR, Graves PM, Andre RG. Field evaluation of enzymelinked immunosorbent assays for $P$. falciparum and $P$. vivax sporozoites in mosquitoes (Diptera: Culicidae) from Papua New Guinea. J. Med Entomol 1987; 24: 433-437.

Wirtz RA, Sattabongkot J, Hall T, Burkot TR, Rosenberg R. Development and evaluation of an enzyme-linked immunosorbent assay for $P$. vivaxVK247 sporozoites. J. Med. Entomol 1992; 29: 854-857.

World Health Organization Division of Control of Tropical Diseases.

Malaria: Important Dates. Disponivel em URL:http://mww.WHO.ch [1995] (WHO - on line).

World Health Organization World malaria situation in 1993. Weekly Epidemiol Rec; 1996b. 71(4):25-32. (WHO).

World Health Organization. Expert Committee on Malaria. Who Tech Rep Ser ; 2000. (WHO - Twentieth Report, 892).

World Health Organization. Ministerial conference on malaria. Weekly Epidemiol. Rec; 1992. 67:349-350. (WHO).

World Health Organization. Procedimentos Laboratoriais em Parasitologia Médica. $2^{\mathrm{a}}$ ed. Livraria Santos; 1999. (WHO).

World Health Organization. World malaria situation in 1993. Weekly Epidemiol Rec ; 1996a. 71(3):17-24. (WHO)

World Health Organization. World malaria situation in 1993. Weekly Epidemiol Rec; 1996c. 71(5):33-40. (WHO)

Zavala F, Tam JP, Masuda A. Syntethetic peptides as antigens for the detection of humoral immunity to Plasmodium falciparum sporozoites. J. Immunol. Meth 1986; 93: 55-61.

Zimmerman RH, Berti J. The importance of integrated control of malaria for the preservation of wetlands in Latin America. In: Global Wetlands, Old and New. New York (NY): ed. W.J. Mitsch. Elsevier Press; 1994. p. 530 .

Zimmerman $\mathrm{RH}$, Voorham J. The use of impregnated bed nets and other materials for the control of malaria in the Americas. Pan Amer $J$ Public Health 1997; 2: 18-25. 
Zimmerman RH. Ecology of malaria vectors in the Americas and future direction. Mem.Inst. Oswaldo Cruz 1992; 87 (3): 371-83. 


\section{ANEXO 1 \\ FICHA DE INVESTIGACÃO DE MALÁRIA \\ IDENTIFICAÇÃO DO PACIENTE}

$\begin{array}{llll}\text { NOME: } & & \\ \text { SEXO: } & 1 \text { MASCULINO } & 2 \text { FEMININO } \\ \text { GRAVIDEZ }: & 1 \text { SIM } & 2 \text { NÃO } & \text { 3 NÃO SE APLICA } \\ \text { IDADE: } & & \\ \text { ENDEREÇO: } & & \\ \text { TELEFONE: } & \text { MUNICIPIO: }\end{array}$

II - INFORMAÇÕES CLÍNICO-LABORATORIAIS

SINTOMAS:

1 FEBRE

2 NÁUSEAS

3 VÔMITO

4 SUDORESE

5 DIARRÉIA

6 CALAFRIO

7 DOR LOMBAR

8 DOR NA NUCA

9 DOR DE CABEÇA

10 DOR MUSCULAR

11 DOR ARTICULAR

12 DOR ABDOMINAL 
13 FALTA DE APETITE

14 MAL ESTAR

15 OUTROS

16 ASSINTOMÁTICO

17 SEM RESPOSTA

DATA DO INICIO DOS SINTOMAS:

1

DATA DA COLETA:

1

DATA DO EXAME:

ESPÉCIE DE PLASMÓDIO
1) P.vivax
2) P.falciparum
3) P. malariae
4) P.ovale
5) associado

\section{DENSIDADE}
1) $+/ 2$
2) +
3) ++
4) +++
5) NĀO SE APLICA

DATA DO INICIO DO TRATAMENTO: 
MEDICAÇÃo UTILIZADA

1 CLOROQUINA

2 AMODIAQUINA

3 PRIMAQUINA

4 SULFATO DE QUININO

5 CLORIDRATO DE QUININO

6 TETRACICLINA

7 CLINDAMICINA

8 DOXICICLINA

9 MEFLOQUINA

10 SEM RESPOSTA

11OUTROS ANTIMALÁRICOS:

III- INFORMAÇŌES EPIDEMIOLÓGICAS

Número de malárias anterior?

Espécie de Plasmódio:

1. P.vivax

2. P.falciparum

3. P.malariae

4. P.ovale

5. Associada (P.vivax + P.falciparum)

6. Não sabe

7. Não teve

Há quanto tempo? Meses

$N^{\circ}$ de Malárias anteriores: 
Medidas profiláticas utilizadas durante o periodo de exposição:

1) $\operatorname{Sim}$

2)Nāo

Quais?

Recebeu transfusão de sangue nos últimos 6 meses ?

1. $\operatorname{Sim}$

2. Não

Onde?

Data:

Onde?

DATA:

Doou Sangue nos últimos 6 meses?

1. Sim

2. Não

Onde?

Data:

É usuário de drogas injetável?

$1 \mathrm{Sim}$

2 Não

Ocupação:

Local provável de infecção:

Localidade: 
Informacõos adicionais:

1. Atividades de lazer:

2. Atividades dentro da mata:

3. Viagens para outras localidados:

4. Você sabo o que é malária?

5. Você sabe os sintomas da malária?

6. Onde vocé 6 atendido quando fica doente?

Investigador:

Data:

Local: 


\section{UNIVERSIDADE DE SÃO PAULO \\ FACULDADE DE SAÚDE PÜBLICA \\ COMITÉ DE ÉTICA EM PESQUISA-COEP \\ Av. Dr. Arnaldo, 715 - sala 18 - sub-solo - Cerqueira cesar \\ Sto Paulo-sP CP: 01246-904 \\ Telefone (Oxo11) 3066-7776 - e-mal1: moracaseusp.br}

\section{Of. COEP/073/99}

12 de maio de 2000

Pelo presente, informo que o Comitê de Ética em Pesquisa da Faculdade de Saúde Pública da Universidade de São Paulo-COEP, analisou e aprovou, em sua 2 $2 / 99$ Sessão Ordinária, de 18.04.2000, de acordo com os requisitos da Resoluçào CNS/196/96, o protocolo de Pesquisa n. ${ }^{\circ}$ 283, intitulado: "ESTUDO DA OCORRÈNCIA DA MALÁRIA NO ESTADO DO AMAPÁ", apresentado pela pesquisadora Maria Stela Branquinho.

Atenciosamente,

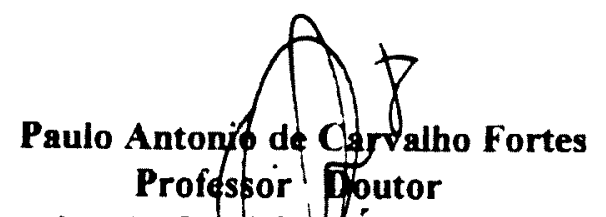

Vice-Coordenador do Conitê d, Ética em Pesquisa da FSP-COEP 
Certa ver um soldado disse ao seu tenente:

Meu amigo não voltou do campo de batalha, senhor, solicito permissão para ir a buscá-lo.

Permissão negada, replicou o oficial. Não quero que arrisque a sua vida por um homem que provavelmente está morto.

O soldado, ignorando a proibição, saiu, e uma hora mais tarde regressou, mortalmente ferido, transportando o cadóver de seu amigo. O oficial estava furioso:

Já tinha dito que ele estava mortol!!

Agora eu perdi dois homens! Diga-me valeu a pena trazer um cadáver?

E o soldado, moribundo, respondeu:

Clarol que sim, senhor! Quando o encontrei, ele dinda estava vivo e pode me dizer:

Tinha certeza que você virial

AMTGO t AQUJLE QUE CHISGA QUANDO TODO MUNDO IÁ SE FOI Autor desconhecido 